DEVELOPMENT OF HIGH PERFORMANCE REFRACTORY FIBERS WITH ENHANCED INSULATING PROPERTIES AND LONGER SERVICE LIFETIMES

Phase I

Enhanced Insulating Properties and Service Lifteime Proof-of-Principle Demonstration

Final Report
By
P. C. Martin
G. L. DePoorter
D. R. Munoz

February 1991

Work Performed Under Contract No. FC07-89ID12880

For

U.S. Department of Energy

Office of Industrial Technologies

Washington, D.C.

By

Manville Sales Corporation

Denver, Colorado

and

Colorado School of Mines

Golden, Colorado 


\section{DISCLAIMER}

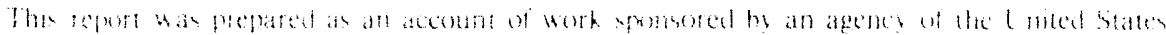

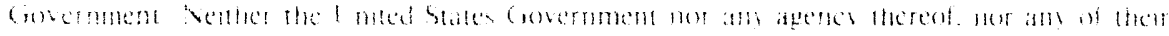

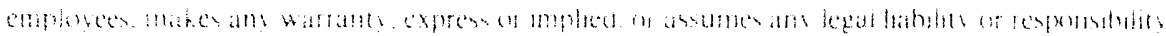

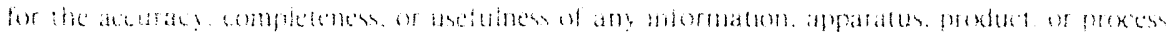

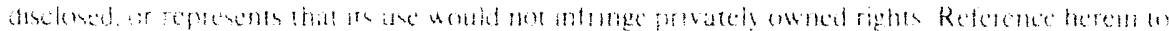

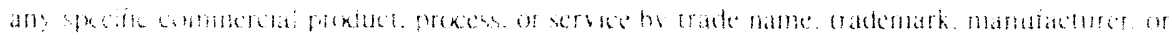

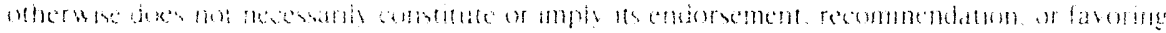

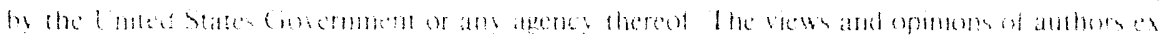

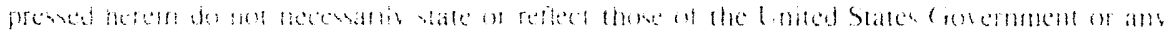
areic: therest

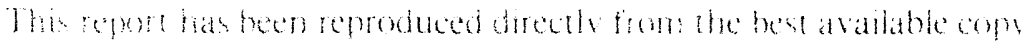

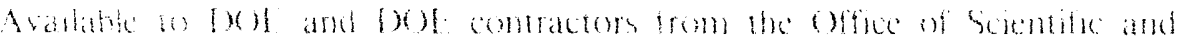

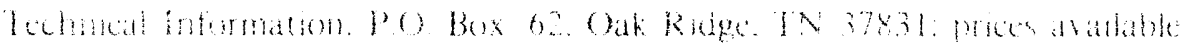

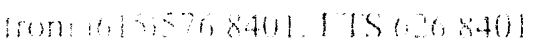

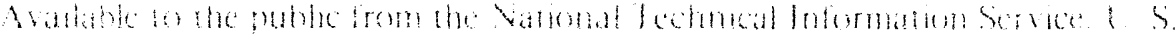

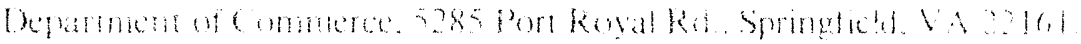




\title{
DEVELOPMENT OF HIGH PERFORMANCE REFRACTORY FIBERS WITH ENHANCED INSULATING PROPERTIES AND LONGER SERVICE LIFETIMES \\ PHASE 1. \\ ENHANCED INSULATING PROPERTIES AND SERVICE LIFETIME PROOF-OF-PRINCIPLE DEMONSTRATION
}

FINAL REPORT

February 1991

P. C. Martin

G. L. DePoorter

D. R. Munoz

Work Performed Under Cooperative Agreement DE-FC07-891D12880

\author{
Prepared for \\ U. S. Department of Energy \\ Idaho Operations Office, Idaho Falls, ID \\ Sponsored by the Office of the Assistant Secretary \\ for Conservation and Renewable Energy \\ Office of Industrial Technologies \\ Washington D.C. \\ Prepared by \\ Manville Sales Corporation \\ Corporate Technical Center \\ P. O. Box 5108 \\ Denver, Colorado 80217-5108 \\ and \\ Colorado School of Mines \\ Golden, Colorado 80401
}




\section{EXECUTIVE SUMMARY}

The Manville Technical Center of the Manville Sales Corporation, Littleton, Colorado and the Metallurgical and Materials Engineering Department and the Engineering Department of the Colorado School of Mines, Golden, Colorado, under United States Department of Energy Cooperative Agreement No. DE-FC07-89ID12880, have initiated a three phase investigation of the development of high performance refractory fibers with enhanced insulating properties and longer usable lifetimes. This report presents the results of the first phase of the study, performed from August 1989 through February 1991, which shows that significant energy savings are possible through the use of high temperature insulating fibers that better retain their efficient insulating properties during the service lifetime of the fibers. The remaining phases of this program include the pilot scale development and then full scale production feasibility development and evaluation of enhanced high temperature refractory insulating fibers.

This first proof of principle phase of the program presents a summary of the current use pattems of refractory fibers, a laboratory evaluation of the high temperature performance characteristics of selected typical refractory fibers and an analysis of the potential energy savings through the use of enhanced refractory fibers.

The current use patterns of refractory fibers span a wide range of industries and high temperature furnaces within those industries. The majority of high temperature fiber applications are in furnaces operating between 2000 and $2600^{\circ} \mathrm{F}$. The fibers used in furnaces operating within this range provide attractive thermal resistance and low thermal storage at reasonable cost. Higher temperature applications require significantly more expensive materials. The applications and analyses of the observed energy savings through the use of existing refractory fibers have been documented in the open literature and are included in the technology data base attached to this report.

A series of heat treatment studies performed for this phase of the program has shown that the refractory fibers, as initially manufactured, have attractive thermal conductivities for high temperature applications but the fibers go through rapid devitrification and subsequent crystal growth upon high temperature exposure. Exposure of the as-manufactured fibers to furnace temperatures well below the service temperatures of the fibers causes significant thermal conductivity and microstructural changes. These changes result in higher hear losses through the furnace walls and shortened fiber service lifetime because of the increased brittleness of the fibers. 
Development of improved fibers, maintaining the favorable characteristics of the existing as-manufactured fibers, could save between 1 and $4 \%$ of the energy consumed in high temperature furnaces using refractory fibers. This savings is on the order of 0.01 to 0.03 quad Btu/y. These savings have been calculated based on models comparing furnaces insulated with existing fibers that degrade and furnaces insulated with the to be developed fiber(s) of this program.

The devitrification studies performed in Phase I indicate that the rate of crystalline phase development is quite rapid but possibly can be limited or suppressed sufficiently so that the fibers can retain the favorable characteristics of the vitreous as-manufactured fibers. Combining the proper refractory oxide phase compositions with properly controlled fiberization processes could result in new improved high temperature fibers. These potential compositions and processes will be explored in the subsequent phases of this program. 


\section{CONTENTS}

EXECUTIVE SUM

1. INTRODUCTION $\ldots \ldots \ldots \ldots \ldots \ldots \ldots \ldots \ldots \ldots \ldots \ldots$

1.1 Project Objectives $\ldots \ldots \ldots \ldots \ldots \ldots \ldots \ldots \ldots \ldots \ldots$

1.2 Summary of Phase I Tasks $\ldots \ldots \ldots \ldots \ldots \ldots \ldots \ldots \ldots 2$

1.3 Organization of Phase I Report $\ldots \ldots \ldots \ldots \ldots \ldots \ldots \ldots$

2. POTENTIAL ENERGY SAVINGS $\ldots \ldots \ldots \ldots \ldots \ldots \ldots \ldots \ldots$

2.1 Existing Energy Consumption Profile in Appropriate Industries $\ldots \ldots \ldots \ldots \ldots \ldots \ldots \ldots$

2.2 Furnace Configurations Modeled $\ldots \ldots \ldots \ldots \ldots \ldots \ldots$

2.3 Results of Energy Savings Calculations $\ldots \ldots \ldots \ldots \ldots \ldots$

2.4 Potential Energy Savings Compared to Savings Criteria $\ldots . .8$

3. TECHNOLOGY SURVEY $\ldots \ldots \ldots \ldots \ldots \ldots \ldots \ldots$

3.1 Refractory Fiber Usage $\ldots \ldots \ldots \ldots \ldots \ldots \ldots \ldots$

3.2 Furnace Types $\ldots \ldots \ldots \ldots \ldots \ldots \ldots \ldots \ldots \ldots \ldots \ldots \ldots$

3.3 Devitrification of Refractory Insulating Fibers $\ldots \ldots \ldots 12$

3.4 Field Trips $\ldots \ldots \ldots \ldots \ldots \ldots \ldots \ldots \ldots \ldots \ldots \ldots$

4. SELECTION OF REPRESENTATIVE REFRACTORY

INSULATING FIBERS FOR EVALUATION $\ldots \ldots \ldots \ldots \ldots 15$

4.1 Rationale for Fiber Selection $\ldots \ldots \ldots \ldots \ldots \ldots \ldots \ldots$

4.2 Purchase of Materials $\ldots \ldots \ldots \ldots \ldots \ldots \ldots \ldots \ldots$

5. THERMAL AND PHYSICAL PERFORMANCE AND CHARACTERIZATION OF SELECTED FIBERS $\ldots \ldots \ldots \ldots 17$ 5.1 Test Sample Preparation $\ldots \ldots \ldots \ldots \ldots \ldots \ldots \ldots \ldots 17$

5.2 Heat Treatment $\ldots \ldots \ldots \ldots \ldots \ldots \ldots \ldots \ldots \ldots \ldots \ldots$

5.3 Shrinkage at $2600^{\circ} \mathrm{F} \ldots \ldots \ldots \ldots \ldots \ldots \ldots \ldots \ldots \ldots 18$

5.4 Thermal Conductivity $\ldots \ldots \ldots \ldots \ldots \ldots \ldots \ldots \ldots$

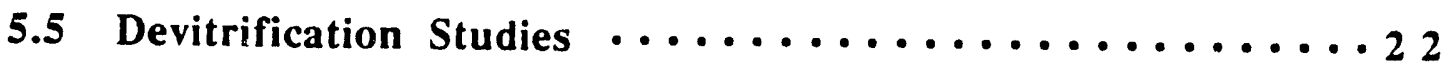

5.6 Significance of the Devitrification Studies $\ldots \ldots \ldots \ldots \ldots 2$ 
6. ENERGY SAVINGS ANALYSIS $\ldots \ldots \ldots \ldots \ldots \ldots \ldots \ldots \ldots$

6.1 Selection of Furnaces for Modeling $\ldots \ldots \ldots \ldots \ldots \ldots \ldots$

6.2 Cylindrical and Box Batch Furnaces $\ldots \ldots \ldots \ldots \ldots \ldots$

6.3 Walking Beam, Rotary Hearth and Tunnel Kiln

Continuous Duty Furnaces ................... 99

6.4 Selection of the Computer Programs $\ldots \ldots \ldots \ldots \ldots \ldots 40$

6.5 Modification of the Computer Codes $\ldots \ldots \ldots \ldots \ldots \ldots 43$

6.6 Fiber Properties Used in the Modeling $\ldots \ldots \ldots \ldots \ldots .43$

6.7 Modeling Results $\ldots \ldots \ldots \ldots \ldots \ldots \ldots \ldots \ldots \ldots \ldots$

6.8 Energy Savings Calculation $\ldots \ldots \ldots \ldots \ldots \ldots \ldots \ldots \ldots$

7. TECHNOLOGY SUMMARY $\ldots \ldots \ldots \ldots \ldots \ldots \ldots \ldots \ldots 48$

8. REFERENCES $\ldots \ldots \ldots \ldots \ldots \ldots \ldots \ldots \ldots \ldots \ldots \ldots$

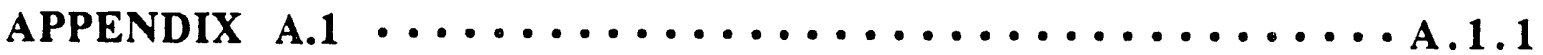

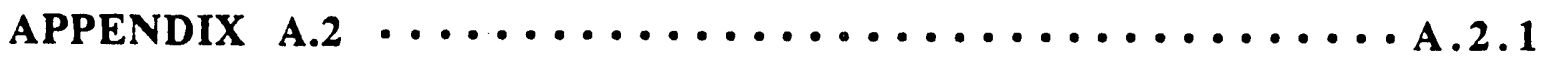

APPENDIX A.3 $\ldots \ldots \ldots \ldots \ldots \ldots \ldots \ldots \ldots \ldots \ldots \ldots \ldots \ldots . \ldots \ldots \ldots$

\section{TABLES}

2.1 Energy Consumption in Appropriate Industries $\ldots \ldots \ldots \ldots \ldots 5$

2.2 Summary of Steady-State Furnace Wall Heat Loss Calculations $\ldots 7$

3.1 Industry, Applications, and Use Temperature for Refractory Insulating Fibers $\ldots \ldots \ldots \ldots \ldots \ldots \ldots \ldots \ldots$

3.2 Commercial Refractory Insulating Fibers Service Temperatures and Oxide Compositions $\ldots \ldots \ldots \ldots \ldots \ldots \ldots \ldots \ldots$

3.3 Industrial Heating Page Citations of Energy Savings Using Insulating Refractory Fibers, 1970-1989 $\ldots \ldots \ldots \ldots \ldots \ldots 12$

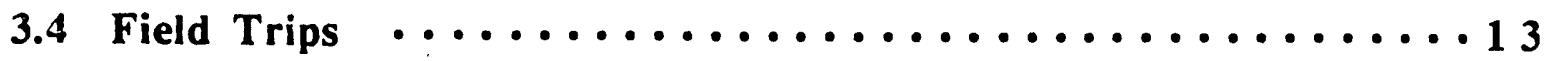

4.1 Fibers Selected for Evaluation $\ldots \ldots \ldots \ldots \ldots \ldots \ldots \ldots \ldots$

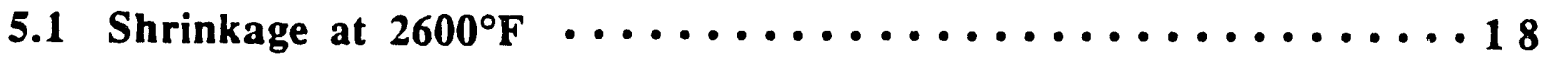

5.2 Apparent Thermal Conductivity at $1000^{\circ} \mathrm{F}$ Mean $\ldots \ldots \ldots \ldots 21$ 
5.3 Devitrification Products in the Five Selected Fibers Fully

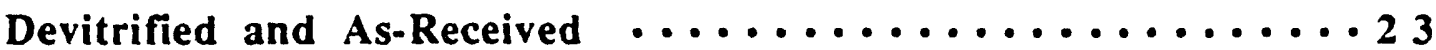

5.4 Heating Times and Temperatures for Detailed

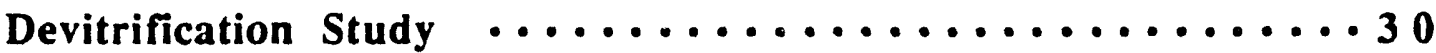

5.5 Crystalline Phases in the Devitrification of Kaowool $2600 \ldots \ldots 31$

5.6 Crystalline Phases in the Devitrification of Kaowool ZR $\ldots \ldots 32$

5.7 Crystalline Phases in the Devitrification of Cerachrome $\ldots \ldots 32$

6.1 Operating Conditions for the Walking Beam Furnace in

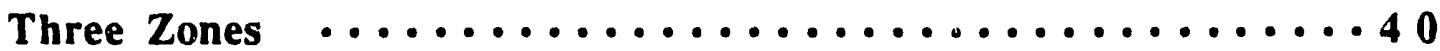

6.2 Temperature Set Point for Industrial Furnace Zones $\ldots \ldots \ldots 40$

6.3 Summary of Steady-State Furnace Wall Heat Loss Calculations .45

6.4 Energy Losses Through the Enhanced and Existing Fiber Wall in the Cylindrical Furnace $\ldots \ldots \ldots \ldots \ldots \ldots \ldots \ldots$

\section{FIGURES}

2.1 Typical Furnace Energy Flow $\ldots \ldots \ldots \ldots \ldots \ldots \ldots \ldots \ldots$

4.1 Refractory Fiber Usage by Application Temperature $\ldots \ldots \ldots 16$

5.1 Linear Shrinkage of Fiber Felts Heat Treated at $2600^{\circ} \mathrm{F} \ldots \ldots 19$

5.2 Thermal Conductivity of Fiber Felts Heat Treated at $2600^{\circ} \mathrm{F} \cdots 22$

5.3 X-Ray Diffraction Patterns for Kaowool ZR at Various Heat Treatment Times at $2600^{\circ} \mathrm{F} \ldots \ldots \ldots \ldots \ldots \ldots \ldots \ldots \ldots \ldots$

5.4 SEM Views of Kaowool ZR at Various Heat Treatment

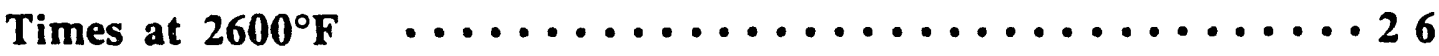

5.5 Amorphous Residuall During Devitrification of Kaowool 2600 - 33

5.6 Amorphous Residual During Devitrification of Kaowool ZR $\cdots 33$

5.7 Amorphous Residual During Devitrification of Cerachrome $\cdots 34$

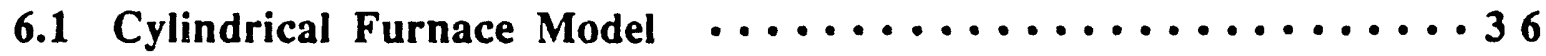

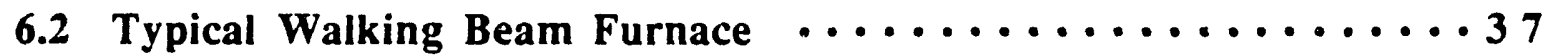

6.3 Typical Rotary Hearth Furnace $\ldots \ldots \ldots \ldots \ldots \ldots \ldots \ldots \ldots$

6.4 Typical Tunnel Kiln Section $\ldots \ldots \ldots \ldots \ldots \ldots \ldots \ldots \ldots \ldots$

6.5 Comparison of DOT and TOPAZ Codes, Cold-Side $\ldots \ldots \ldots 42$

6.6 Comparison of DOT and TOPAZ Codes, Wall Mid-Plane $\cdots . .42$ 
DEVELOPMENT OF HIGH PERFORMANCE REFRACTORY FIBERS WITH ENHANCED INSULATING PROPERTIES AND LONGER SERVICE LIFETIMES

\section{PHASE I: ENHANCED INSULATING PROPERTIES AND SERVICE LIFETIME PROOF-OF-PRINCIPLE DEMONSTRATION}

\section{INTRODUCTION}

\subsection{Project Objectives}

The overall objective of this research project (under Cooperative Agreement N0. DE-FC0789ID 12880) is the development of improved high performance refractory fibers with enhanced insulating properties and longer service lifetimes. Included is:

- The exploitation of a more complete silica, alumina, and zirconia ternary phase diagram

- The assessment of current technology, including the development of a data base of existing fibers application in the glass, aluminum, cement, iron, and steel industries.

- The development of new fibers with the goals of higher service temperatures, lower shrinkage during use, improved long-term thermal properties, increased lifetime projections, and better understood and controlled properties

- The production and testing of new fibers at pilot and full plant scales

- The assessment of the energy and cost savings attainable through the development of improved fibers

- The transfer of research results to industry.

Titles of each of the phases and corresponding objectives are listed as:

Phase I: Enhanced Insulating Property and Service Lifetime Proof-of-Principle

To assess the current technology and use pattems of existing refractory fibers, to establish a data base on currently used refractory fibers, and to develop an estimate of the potentially attainable energy savings as a result of developing enhanced insulating property and service lifetime fibers.

\section{Phase II: Improved Refractory Fiber and Industrial Benefit Development}

To develop new refractory fiber compositions, to expand the data base under development, produce new fibers at pilot-scale, evaluate the production methods and produced fibers, and select candidate fiber compositions for subsequent full-scale production and industrial tests. 


\section{Phase III: Pre-Commercialization of Technology}

To evaluate full-scale production of improved fibers, perform full-scale industrial tests, evaluate the characteristics of improved refractory fibers, continue assessments of industrial interest in the benefits of improved refractory fibers, finalize the energy and cost savings analyses, and to transfer the results of this research to industry.

\subsection{Summary of Phase I Tasks}

\section{Task 1 - Develop Existing Technology Database}

A data base shall be developed, using data acquired by way of a literature search and survey of refractory fiber users in high volume end-use industries such as iron and steel, glass, cement, and aluminium. The data base shall be used for the determination of potential thermal energy savings.

\section{Task 2 - Select Fibers for Evaluation}

Refractory fibers shall be selected, from those identified in Task 1, for sample characterization, and thermal property determination.

\section{Task 3 - Determine Thermal Properties}

Determine the thermal conductivity of insulating materials produced from the selected fibers, asmanufactured and as thermally treated, at operating and extreme temperatures.

\section{Task 4 - Perform Sample Characterization}

Characterize the structure, volume changes, and phase transformations of the selected fibers, asmanufactured and as thermally treated, at operating and extreme temperatures. The characterization data will be correlated with the thermal property data and all data will become part of the database under deveiopment.

\section{Task 5 - Estimate Energ; Savings}

Energy savings shall be estimated by comparing the data assembled in this phase of the project with that potentially achievable from the development of enhanced insulating property and service lifetime fibers. The estimate shall be reviewed with the Department of Energy (DOE), and no further research will be performed if a potential energy savings of 0.01 quad Btu/y is not achievable.

Task 6 - Provide Phase I Report 


\subsection{Organization of Phase I Report}

For reporting purposes, the results of Phase I will be reported in a different order than the tasks summarized above. The results will be presented as follows:

Potential Energy Savings: The potential energy savings resulting from the usage of improved refractory fibers will be described using the results of information obtained during this study. The basis of the calculations of the energy savings will be described in further detail in the section on Energy Savings Analysis.

Technology Survey: The technology survey includes information gained from:

1. A search of open literature on typical furnaces, insulation properties, material properties, and furnace models

2. Field trips to industrial users of refractory fibers

3. A review of available manufacturer's literature

4. Government documents

5. Private communications with users, furnace manufacturers, and others.

Selection of Representative Refractory Insulating Fibers for Evaluation: The criteria for fiber selection and the acquiring of the selected fibers is described.

Thermal and Physical Performance and Characterization of Selected Fibers: The thermal treatment and resulting tests of thermal performance and physical characterization of the fibers are described. The results of the tests on the fibers has become the basis for the energy savings analysis and an indication of direction for improving the thermal performance of refractory fibers.

Energy Savings Analysis: Further details of the calculation of energy losses in typical furnaces is given. This analysis is the basis for the demonstration of at least 0.01 quad Rtu/y potential energy savings.

Technology Summary (Data base): The accumulation of pertinent data is presented as the technology summary. 


\section{POTENTIAL ENERGY SAVINGS}

\subsection{Existing Energy Consumption Profile in Appropriate Industries}

Appropriate industries are defined as those industries where use of refractory fiber insulating materials is feasible. Conditions where use of refractory fiber is not feasible can be broken into two categories; (a) furnace linings exposed to severe corrosive chemical environments such as those common in the aluminum, glass, cement, and chemical industries and (b) in situations where mechanical abrasion is present, such as the hearth, floor, traveling car or any part of the furnace that must support the product load in both continuous or batch processes.

A search for detailed energy consumption data focused on the primary metal reheat, ferrous metal heat treating and ceramic heating processes. The energy consumption in these processes provides the most conservative estimate of potential energy savings when using an improved refractory fiber over fibers that are commercially available. An excellent source of information was found in a report to the Gas Research Institute (GRI) by McDermott and Chapman (1988). The energy consumption data published in this report are subdivided into categories that are consistent with appropriate industrial processes for this study. These energy consumption data were verified by other reports including another GRI report (Koch, McDermott and Klareich, 1987) and a DOE report published by the Energy Information Administration (EIA) (1988). In addition, contacts were made in person with local manufacturers of steel (Riley and Ellers, 1990; Moore and Walker, 1989) and clay brick products (Stumpff, 1989) and by phone conversations with several major aluminum (Lippert, 1990, Jacobs, 1990, and Sterahan, 1990) and steel (Christiansen, 1989) industries.

Because it has been difficult to specifically identify the fraction of the Chemical and Allied Products and Petroleum and Coal Products industrial processes that can be characterized as having corrosive environments, these were left out of the primary energy savings calculation. However, there may indeed be applications within these industries where refractory fiber use is feasible and future efforts should be made to estimate the potential energy savings in this category. Additionally, it is unnecessary to include the energy consumption in these industries to show that 0.01 quad of energy could be saved with the development of an improved refractory fiber.

The energy consumption data utilized for this study are summarized below in Table 2.1. The furnace fuel types are broken into two categories; electrically heated and natural gas and other fuels. The sum of the electrical energy column was divided by 0.34 , which represents the 
efficiency of converting the electricity from another fuel (such as fossil, nuclear, hydivelectric or solar), then added to the sum of furnace thermal energy provided by natural gas or other fuels. As shown in Table 2.1, it is estimated that in 1985, 0.7035 quad of energy were consumed in industries deemed appropriate for this study.

Several articles were found that provided energy flow (Sankey) diagrams for various furnace configurations (Casana and Stabile, 1983, Hollander and IJmuiden, 1983, Molloy, 1985, and Vis':-anta and Menguc, 1987). A typical energy flow diagram is provided in Figure 2.1. In addition, the GRI report by Korh, (1987) provides detailed furnace energy balance information on batch and continuous furnaces used in the ferrous metal heat treating industries.

As shown in Figure 2.1, the flow of energy ont of the furnace is typically divided into three portions. The largest fraction, 30 to $50 \%$ of the energy input generally is lost through the flue. Typically 30 to $35 \%$ of the energy input will leave with the product. The remainder (10 to 20\%) of the energy will exit through the furnace walls in sieady-stare operation or is lost through energy storage in the batch processes. Therefore, a range of from 10 to $20 \%$ of the energy input to the furnace is used to estimate the wall energy losses for furnaces typical of the industries that use refractory fiber insulation.

Table 2.1 Energy Consumption in Appropriate Industries

\begin{tabular}{|c|c|c|c|}
\hline \multirow[b]{2}{*}{ PROCESS } & \multicolumn{3}{|c|}{ Energy Consumption $\left(10^{12} \mathrm{BTU}\right)$} \\
\hline & Electrical & Gas + Other & Total \\
\hline Steel Reheat & 1.9 & 171.2 & 173.1 \\
\hline Steel Soaking Pit & 0.0 & 45.1 & 45.1 \\
\hline Ferrous + Nonferrous Forging & 1.6 & 20.1 & 21.7 \\
\hline Aumosphere Generation (Exo+Endothermic) & 0.0 & 39.0 & 39.0 \\
\hline Aluminum Heating & 3.2 & 12.6 & 15.8 \\
\hline Ferrous Metal Heat Treating & 42.2 & 165.6 & 207.8 \\
\hline Copper Heat Tieating & 1.5 & 6.1 & 7.6 \\
\hline Brick and Structure Clay Tile & 0.0 & 48.4 & 48.4 \\
\hline Refractories & 0.0 & 7.2 & 7.2 \\
\hline Structural Clay Products & 0.0 & 2.7 & 2.7 \\
\hline Ceramic Wall + Floor Tile & 0.0 & 6.8 & 6.8 \\
\hline Aluminum Anode Baiking & 0.0 & 7.7 & 7.7 \\
\hline Agglomeration / Sintering (Iron Ore) & 0.0 & 22.8 & 22.8 \\
\hline $\begin{array}{l}\text { Totals (* indicate } 34 \% \text { efficiency for } \\
\text { electrical energy production) }\end{array}$ & $\begin{array}{c}50.4 \\
148.2 *\end{array}$ & 555.3 & $\begin{array}{r}605.7 \\
703.5\end{array}$ \\
\hline
\end{tabular}


Figure 2.1 Typical Furnace Energy Flow

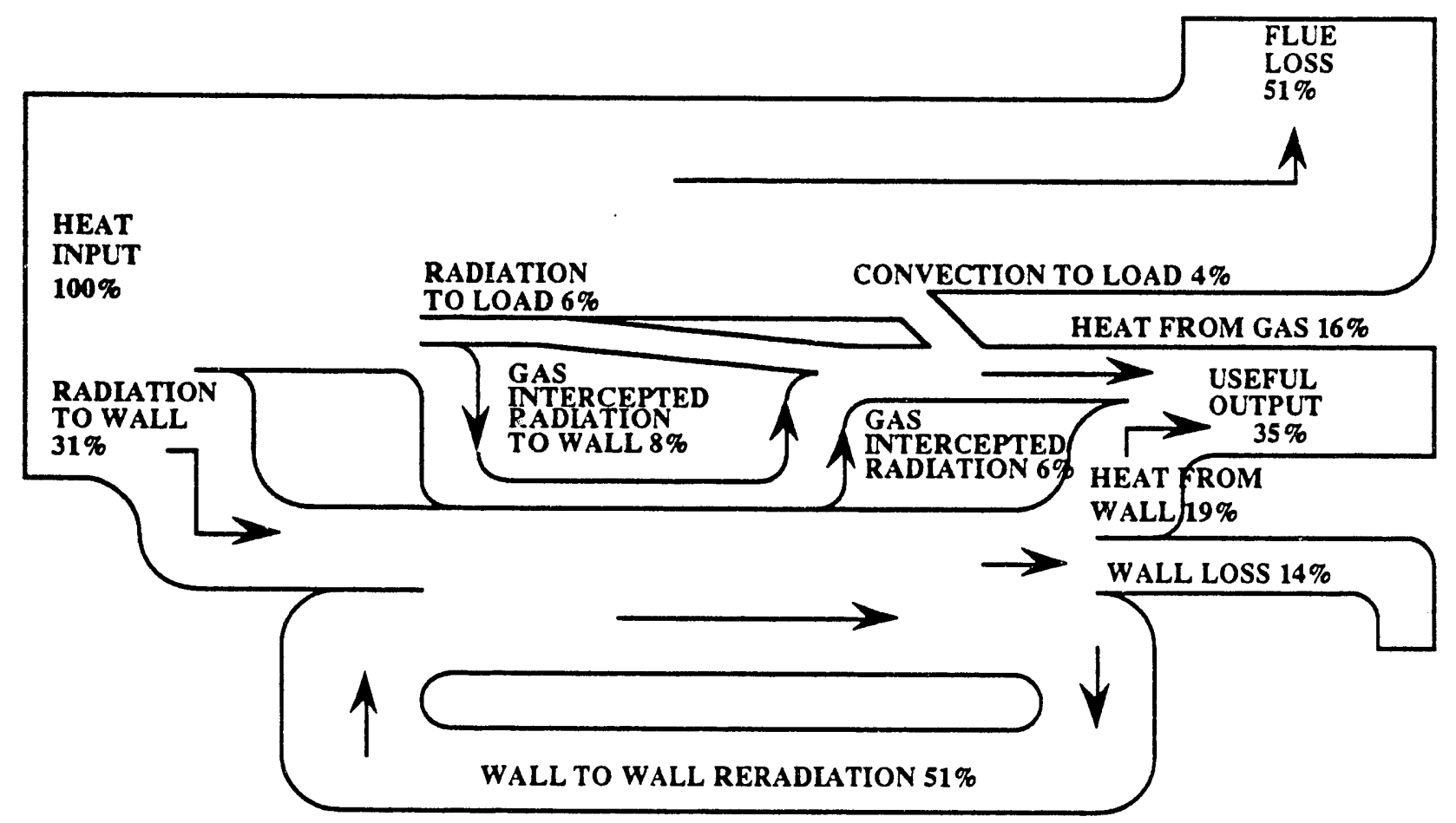

\subsection{Furnace Configurations Modeled}

This section provides a summary of the modeled furnaces. More detailed information can be found in Subsection 6.2. One batch furnace and three continuous duty furnaces were modeled. Because the computer codes were limited to two-dimensional calculation domains, only the axisymmetric or cylindrical (bell type) batch furnace was modeled numerically. However, hand calculations were performed for the steady state heat losses from a box furnace and are compared with the results from the cylindrical furnace model in Subsection 6.2.

Three continuous duty furnaces were also modeled and are listed as follows:

1. Tunnel kiln, with rectangular vertical cross section, used for firing clay brick, refractories, and whitewares

2. Walking beam furnace (similar to the tunnel kiln), with rectangular vertical cross section and a moving beam mechanism to propel the product through the furnace, used to reheat steel or nonferrous metals

3. Rotary hearth furnace, with rectangular vertical cross section but toroidal horizontal cross-section, also used to reheat metal and fire ceramics. 


\subsection{Results of Energy Savings Calculations}

The results of the energy savings calculations are provided in tabular form in this section. Properties of the existing refractory fibers were determined by the measurements of bulk thermal conductivity and shrinkage as described in Section 5. These are the in-service properties of the commercially available fibers. After the heating of the fibers as a result of being used in a furnace, the fibers show devitrification and consequently have increased thermal conductivity and are more brittle than the as-received fiber. The properties of the enhanced refractory fiber were assumed to be those of the as-received commercial fibers, representative of the properties of an improved or enhanced fiber. The thermal conductivities of the as-received fibers were measured using the same techniques used for the heat treated fibers, as indicated in Section 5. The steady state results of the energy savings calculations are summarized below in Table 2.2. In general, 11 to $19 \%$ of the thermal energy transported through the furnace wall can be saved when a fiber that does not devitrify (enhanced) is used in place of commercially available, that is, existing refractory fibers that have experienced heat treatment.

Results of the heat storage from the transient analyses of the cylindrical batch furnace were not included here because there is only a small difference in energy savings, $\sim 4 \%$, when an enhanced fiber is used in place of an existing fiber. Also, it was assumed in this transient analysis that the furnace was completely cooled to standard ambient air temperature. Complete cooling is an unrealistic assumption for most industrial applications unless the furnace is being rebuilt (according to Koch, 1987, this may occur only once every several years, depending on the particular process). Uncertainty in the temperature to which the furnace is cooled between batch cycles added to the reasons for not considering the heat storage terms in the energy savings calculations.

Table 2.2 Summary of Steady-State Furnace Wall Heat Loss Calculations

\begin{tabular}{||l|c|c|c||}
\hline \multirow{2}{*}{ FURNACE TYPE } & \multicolumn{2}{|c|}{ Wall Heat Loss (BTU/day) } & \multirow{2}{*}{$\begin{array}{c}\text { ENERGY } \\
\text { SAVINGS, } \\
(\%)\end{array}$} \\
\cline { 2 - 3 } & Existing Fiber & Enhanced Fiber & 19.2 \\
\hline Cylindrical (Batch) & $2.049 \times 10^{7}$ & $1.655 \times 10^{7}$ & 15.5 \\
\hline $\begin{array}{l}\text { Walking Beam } \\
\text { (Continuous) }\end{array}$ & $2.179 \times 10^{6}$ & $1.841 \times 10^{6}$ & 10.9 \\
\hline $\begin{array}{l}\text { Rotary Hearth } \\
\text { (Continuous) }\end{array}$ & $2.640 \times 10^{8}$ & $2.353 \times 10^{8}$ & 18.6 \\
\hline $\begin{array}{l}\text { Tunnel Kiln } \\
\text { (Continuous) }\end{array}$ & $3.842 \times 10^{6}$ & $3.126 \times 10^{6}$ & \\
\hline
\end{tabular}




\subsection{Potential Energy Savings Conspared to Savings Criteria}

Potential energy savings are calculated using each portion of information summarized above. It is known that 10 to $20 \%$ of the energy input to the furnace passes through the wall and that 11 to $19 \%$ of this wall loss can be conserved by using an improved fiber. The product of these percentages yields the fraction of energy that potentially can be saved when the improved refractory fiber is used in the appropriate industrial process. Therefore, 1.1 to $3.8 \%$ of the energy consumed ( 0.7035 quad in 1985) yields 0.0077 to 0.027 quad of energy saved. The criterion for this study was to show that 0.01 quad potentially could be saved if an improved refractory fiber were developed to replace commercially available refractory fibers. The average potential energy savings is 0.017 quad, $70 \%$ larger than the criterion.

There are enormous potential energy savings in the conservative listing of processes shown in Table 2.1. However, figures from the EIA report for the Department of Energy (1988) also provide general energy consumption data for the Chemicals and Allied Products (3.567 quad) and the Petroleum and Coal Products (5.123 quad) industries. These industries may also include processes where there is potential for substantial energy savings through the use of refractory fiters. Further detailed analysis will be required to provide a conservative list similar to that of Table 2.1. However, if it is assumed that $50 \%$ of the energy consumed in these industries is related to high temperature processes $\left(500\right.$ to $1500^{\circ} \mathrm{C}$ ), if $10 \%$ of this energy flows through the process container walls, and if $10 \%$ of this energy can be saved through use of an improved refractory fiber then an additional 0.044 quad potentially could be saved annually. 


\section{TECHNOLOGY SURVEY}

Industrial heating applications that currently use refractory insulating fibers were surveyed to provide a basis for the calculation of energy savings that could be realized if improved refractory fibers were developed. The utilization of the improved fibers would be limited to furnaces where refractory insulating fibers are currently being used or potentialiy could be used. Specific examples of energy savings by using refractory insulating fibers were also documented. The technical literature was surveyed to find information on the behavior of refractory fibers subjected to heat treatment.

Computer assisted literature searches were performed in the SHE Engineering Index, Compendex Plus, and Chemical Abstracts. Compendex Plus and the SHE Engineering Index were searched for information on furnaces, furnace design, fiber utilization in furnaces, fiber properties, and energy savings because of using refractory insulating fibers. Chemical Abstracts was searched for technical information on the devitrification (recrystallization) of alumino-silicate fibers. A complete listing of the references found including title, literature citation, and general subject area is included in Appendix A.1.

\subsection{Refractory Fiber Usage}

Industries, applications within industries, and use temperatures of refractory insulating fibers are summarized in Table 3.1. Commercial refractory insulating fibers, their service temperatures, oxide compositions, and manufacturers are summarized in Table 3.2. Note that the refractory insulating fibers are divided into fibers that are vitreous or amorphous as manufactured and fibers that are polycrystalline as manufactured.

Refractory fiber insulation is a recommended and accepted material for industrial furnaces. A study sponsored by the Gas Research Institute (Kerfer 1986) recommends that some form of fiber insulation should be given serious consideration for all furnaces. This recommendation is based on experimental studies of furnaces. The GRI study:

1. Describes insulating fiber compositions, manufacturers, and service temperatures

2. Shows typical applications

3. Describes the installation options

4. Lists a series of Do's and Don'ts for refractory fiber usage

5. Describes several case studies. 
Many specific instances of reported energy savings by using refractory insulating fibers have been reported in the literature. For example, during the time period from 1970 through 1989, 78 articles appeared in Industrial Heating reporting documented energy savings by using refractory fibers. Table 3.3 details the specific references to these articles by year, month and page.

The widespread industrial use of refractory insulating fibers and the documented energy savings by using refractory insulating fibers have been illustrated in Tables 3.1 and 3.2. Therefore, there is potential for even more energy savings if an improved refractory fiber could be developed and produced.

Table 3.1 Industry, Application, and Use Temperature for Refractory Insulating Fibers

\begin{tabular}{|c|c|c|}
\hline INDUSTRY & APPLICATION & $\begin{array}{c}\text { TEMPERATURE } \\
\left({ }^{\circ} \mathrm{F}\right)\end{array}$ \\
\hline $\begin{array}{l}\text { Industrial inorganic } \\
\text { chemicals }\end{array}$ & $\begin{array}{l}\text { Heater and reformer linings } \\
\text { Catalyst filter }\end{array}$ & $\begin{array}{c}2200 \text { to } 2600 \\
2300\end{array}$ \\
\hline Agricultural chemicals & Lining of hot-gas ducts & 2000 to 2300 \\
\hline Petroleum refining & Iieater and reformer linings & 2200 to 2600 \\
\hline Glass & $\begin{array}{l}\text { Glass tank crowns } \\
\text { Regenerator walls } \\
\text { Dog house }\end{array}$ & $\begin{array}{c}? \\
2300 \\
2300\end{array}$ \\
\hline Ceramic & $\begin{array}{l}\text { Kiln linings } \\
\text { Low-mass kiln cars } \\
\text { Kiln car seals }\end{array}$ & $\begin{array}{c}2200 \text { to } 2600 \\
2300 \\
2300\end{array}$ \\
\hline Iron and steel & $\begin{array}{l}\text { Soaking pit cover seals } \\
\text { Reheat furnaces } \\
\text { Tundish cover seal } \\
\text { Coreless induction furnace } \\
\text { Forge furnaces }\end{array}$ & $\begin{array}{c}2300 \\
2200 \text { to } 2600 \\
2000 \text { to } 2300 \\
2300 \\
2200 \text { to } 2600\end{array}$ \\
\hline $\begin{array}{l}\text { Nonferrous } \\
\text { metals }\end{array}$ & $\begin{array}{l}\text { Reheat furnaces } \\
\text { Soaking pit cover seals } \\
\text { Coreless induction furnaces } \\
\text { Heat treating furnaces } \\
\text { Tundish cover seals } \\
\text { Forge furnaces } \\
\end{array}$ & $\begin{array}{c}2200 \text { to } 2600 \\
2300 \\
2300 \\
1800 \text { to } 2600 \\
2000 \text { to } 2300 \\
2200 \text { to } 2600 \\
\end{array}$ \\
\hline
\end{tabular}


Table 3.2 Commercial Refractory Insulating Fibers Service Temperatures and Oxide Compositions

\section{A. As-Manufactured Vitreous Fibers}

\begin{tabular}{|c|c|c|c|c|c|c|}
\hline \multirow{2}{*}{$\begin{array}{l}\text { SER VICE } \\
\left.\qquad{ }^{\circ} \mathbf{F}\right)\end{array}$} & \multirow[t]{2}{*}{ MANUFACTURER } & \multirow{2}{*}{ PRODUCT TRADE NAME } & \multicolumn{4}{|c|}{$\begin{array}{c}\text { OXIDE COMPOSITION } \\
\left(W_{t} \%\right)\end{array}$} \\
\hline & & & AI & $\overline{\mathrm{Si}}$ & $\overline{Z_{r}}$ & $\overline{\mathrm{Cr}}$ \\
\hline 1400 & Carborundum & Fibermat & $?$ & $?$ & - & \\
\hline 1600 & Manville & Cerawool Blanket & 40 & 50 & - & \\
\hline 1800 & $\begin{array}{l}\text { Carborund:um } \\
\text { Thermal Ceramics }\end{array}$ & $\begin{array}{l}\text { Duraback } \\
\text { Blanket B } \\
\text { Kaowool Wet Felt }\end{array}$ & $\begin{array}{l}40 \\
44 \\
?\end{array}$ & $\begin{array}{l}57 \\
50 \\
?\end{array}$ & $\begin{array}{l}- \\
-\end{array}$ & $\overline{-}$ \\
\hline 1900 & Thermal Ceramics & Pyro-Bloc E & 47 & 53 & - & - \\
\hline 2000 & $\begin{array}{l}\text { Carborundum } \\
\text { Thermal Ceramics }\end{array}$ & $\begin{array}{l}\text { Moist-Pack D } \\
\text { Kaowool Bulk A,D,C } \\
\text { Blanket }\end{array}$ & $\begin{array}{l}35 \\
45 \\
49\end{array}$ & $\begin{array}{l}63 \\
53 \\
51\end{array}$ & $\overline{-}$ & $\overline{-}$ \\
\hline 2150 & Thermal Ceramics & $\begin{array}{l}\text { HP Blanket, HP Fiber } \\
\text { Pyro-Log R Grade Fiber }\end{array}$ & $\begin{array}{l}47 \\
47\end{array}$ & $\begin{array}{l}53 \\
53\end{array}$ & - & - \\
\hline 2200 & $\begin{array}{l}\text { Carborundum } \\
\text { Thermal Ceramics }\end{array}$ & $\begin{array}{l}\text { Anchor-Loc } 2200, \text { Bonded } 22 \\
\text { Pyro-Bloc Y/T-Bar Y:R } \\
\text { Unibloc/Saber Bloc II: HP }\end{array}$ & $\begin{array}{l}40 \\
47 \\
47\end{array}$ & $\begin{array}{l}52 \\
53 \\
53\end{array}$ & $\begin{array}{l}5 \\
- \\
-\end{array}$ & $\bar{z}-$ \\
\hline 2300 & Carborundum & $\begin{array}{l}\text { Durablanket, HP-S } \\
\text { KTMX Fiber } \\
\text { Long Staple Fiber, PH Blanket } \\
\text { Spun Bulk, Durablanket HP-S } \\
\text { Durablanket } \\
\text { Regular Bulk, Lo-Con Felt } \\
2600 \text { Blanket } \\
\end{array}$ & $\begin{array}{l}40 \\
43 \\
44 \\
45 \\
46 \\
49 \\
49\end{array}$ & $\begin{array}{l}52 \\
54 \\
51 \\
55 \\
51 \\
51 \\
51 \\
\end{array}$ & $\begin{array}{l}5 \\
\overline{5} \\
- \\
- \\
- \\
-\end{array}$ & $\begin{array}{l}- \\
- \\
- \\
- \\
-\end{array}$ \\
\hline 2400 & $\begin{array}{l}\text { Thermal Ceramirs } \\
\text { Carborundum } \\
\text { Manville }\end{array}$ & $\begin{array}{l}\text { Pyro-Log ZR Grade Fiber } \\
\text { ZR Blanket, ZR Fiber } \\
\text { Anchor-Loc } 2400 \text {, Bonded } 24 \\
\text { Cerablanket, Cerafiber }\end{array}$ & $\begin{array}{l}32 \\
34 \\
45 \\
47\end{array}$ & $\begin{array}{l}48 \\
46 \\
55 \\
53\end{array}$ & $\begin{array}{l}20 \\
20 \\
- \\
-\end{array}$ & $\begin{array}{l}- \\
- \\
-\end{array}$ \\
\hline 2500 & Thermal Ceramics & $\begin{array}{l}\text { Pyro-Bloc Y/T-Bar Y:ZR } \\
\text { Unibloc/Saber Bioc II: ZR }\end{array}$ & $\begin{array}{l}32 \\
32\end{array}$ & $\begin{array}{l}48 \\
48\end{array}$ & $\overline{20}$ & - \\
\hline 2550 & $\begin{array}{l}\text { Manville } \\
\end{array}$ & Cerachem & $?$ & $?$ & $?$ & - \\
\hline 2600 & $\begin{array}{l}\text { Carborundum } \\
\text { Manville }\end{array}$ & $\begin{array}{l}\text { Anchor-Loc } 2600 \text {, Bonded } 2600 \\
\text { Durablanket } 2600 \\
\text { Cerachrome Blanket, Felt }\end{array}$ & $\begin{array}{l}30.5 \\
30.5 \\
43\end{array}$ & $\begin{array}{l}53.5 \\
53.5 \\
55\end{array}$ & $\begin{array}{l}16 \\
16 \\
-\end{array}$ & $\overline{-}$ \\
\hline 2700 & Thermal Ceramics & Pyro-Bloc Plus: $\mathrm{Cr}$ & 66 & 32 & - & 2 \\
\hline 2800 & Carborundum & Bonded 30 & 75 & 23 & - & - \\
\hline
\end{tabular}

\section{B. As-Manufactured Polycrystalline Fibers}

\begin{tabular}{|c|c|c|c|c|c|c|}
\hline \multirow{2}{*}{$\begin{array}{c}\text { SER VICE } \\
\left({ }^{\circ} \mathbf{F}\right)\end{array}$} & \multirow[t]{2}{*}{ MANUFACTURER } & \multirow{2}{*}{ PRODUCT TRADE NAME } & \multicolumn{4}{|c|}{ 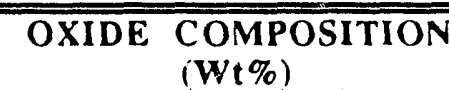 } \\
\hline & & & Al & $\mathbf{S i}$ & $\overline{\mathrm{Zr}}$ & $\mathrm{Cr}$ \\
\hline 2800 & Thermal Ceramics & $\begin{array}{l}\text { Saffil, Bilk, Kaowool HT } \\
\text { Saber Bloc II } \\
\text { Unifelt } 300 \text { (HT) }\end{array}$ & $\begin{array}{r}96 \\
96 \\
<96\end{array}$ & $\begin{array}{r}4 \\
4 \\
>4\end{array}$ & $\begin{array}{l}- \\
-\end{array}$ & $\overline{-}$ \\
\hline 2900 & Thermal Ceramics & Unifelt XT & $<96$ & $>4$ & - & $\overline{-}$ \\
\hline 3000 & Carborundum & Fibermax Bulk Fiber, Mat & 72 & 37 & - & - \\
\hline
\end{tabular}


Table 3.3 Industrial Heating Page Citations of Energy Savings Using Insulating Refractory Fibers, 1970 to 1989

\begin{tabular}{|c|c|c|c|c|c|c|c|c|c|c|c|c|}
\hline $\begin{array}{c}\text { MONTH } \\
\text { YEAR }\end{array}$ & JAN & FEB & MAR & A PR & MAY & JUN & JUL & AUG & SEP & OCT & NOV & DEC \\
\hline $\mathbf{1 9 7 0}$ & 122 & & & & & & & & & & & \\
\hline $\mathbf{7 1}$ & & & & & & & & & 1789 & 2014 & & \\
\hline $\mathbf{7 2}$ & & & & & & & & & 1790 & 1905 & & \\
\hline $\mathbf{7 3}$ & & & 505 & & 905 & 1097 & & & & 1855 & 57 & \\
\hline $\mathbf{7 4}$ & & & & 58 & 74 & & & & 81 & & & \\
\hline $\mathbf{7 5}$ & & & & & & & & & 67 & & 75 & 59 \\
\hline $\mathbf{7 6}$ & & & 58 & 33 & & & 50 & & 54 & 52 & & \\
\hline $\mathbf{7 7}$ & & & & 14 & 47 & & & 36 & & & & \\
\hline $\mathbf{7 8}$ & & & & 20 & 38 & & & 42 & & & & 37 \\
\hline $\mathbf{7 9}$ & & & 32 & 18 & & 47 & 41 & & 46 & 36,38 & & \\
\hline $\mathbf{1 9 8 0}$ & 34 & & & 63 & 44 & & & 41 & 37,38 & & & \\
\hline $\mathbf{8 1}$ & & & & 24,29 & & 42 & & & & & 42 & \\
\hline $\mathbf{8 2}$ & 39 & & & 12,17 & & 54 & 38 & & 38 & 43 & & 22 \\
\hline $\mathbf{8 3}$ & & & 30,32 & & & & 12,15 & & 46 & & & \\
\hline $\mathbf{8 4}$ & & & & 28,34 & & & 31,34 & & & 46 & 42 & \\
\hline $\mathbf{8 5}$ & & & 24 & 55 & & & 36 & 41 & & & & \\
\hline $\mathbf{8 6}$ & & & & 20 & & & & & & & 52 & \\
\hline $\mathbf{8 7}$ & & & & & & & & & & & 24,28 & 35 \\
\hline $\mathbf{8 9}$ & & & & 28,34 & & 23 & & & & & & \\
\hline
\end{tabular}

\subsection{Furnace Types}

Several examples of furnace type are illustrated in the Gas Research Institute (GRI) Report mentioned above. In addition, natural gas fueled furnaces are described in detail in another GRI report (Koch, 1987). The furnace configurations used for the energy savings analysis in this report are described in Section 6.

\subsection{Devitrification of Refractory Insulating Fibers}

Refractory insulating fibers are installed in two different physical states, vitreous and polycrystalline. The vitreous fibers are more widely used and generally less expensive than the polycrystalline fibers. However, the vitreous fibers are known to shrink and become brittle during use. This shrinkage and brittleness result from initially vitreous or amorphous fiber devitrifying or becoming crystalline upon exposure to heat at typical furnace operating temperatures.

Several experimental studies of the devitrification or recrystallization of alumino-silicate refractory fibers have been reported. The shrinkage has been associated with the devitrification or 
recrystallization of the fibers. However, none of these studies report measuring the thermal conductivity of the fibers as a function of heat treatment.

The results of these studies are summarized as follows. For vitreous fibers containing only alumina $\left(\mathrm{Al}_{2} \mathrm{O}_{3}\right)$ and silica $\left(\mathrm{SiO}_{2}\right)$, mullite $\left(3 \mathrm{Al}_{2} \mathrm{O}_{3} \cdot 2 \mathrm{SiO}_{2}\right)$ begins to crystallize at about $1000^{\circ} \mathrm{C}$ with cristobalite appearing at temperatures of about $1300^{\circ} \mathrm{C}$ (Ganz and Kronert 1982, Courrier, 1982, Gaodu, 1977). The addition of chromia $\left(\mathrm{Cr}_{2} \mathrm{O}_{3}\right)$ increased the thermal resistance of the fiber (Schulle, 1986). The results of these studies are summarized in detail in the work of Lo (1991).

\subsection{Field Trips}

Plant visits were made to several facilities where refractory insulating fibers are being used. These included a brick manufacturing plant, a modern ceramics production facility, a s:zel producing plant, and a brass production facility. Other manufacturers were contacted by telephone. Other technical people with experience in using refractory insulating fibers were also contacted. The information obtained from these visits is summarized in Table 3.4. These plant visits and personal contacts were conducted in the beginning of the project. The information obtained was utilized in the selection of typical furnaces for modeling and other factors in the energy savings calculations.

Table 3.4 Field Trips

A. Plant Facilities Visited

\begin{tabular}{|l|l||}
\hline Company Product & \multicolumn{1}{|c|}{ Relevant Information Obtained } \\
\hline Brick & $\begin{array}{l}\text { Furnace Type: Tunnel kiln. } \\
\text { Very little fibrous insulation is currently being used at this location, however } \\
\text { another local brick manufacturer uses fibrous modules throughout their furnaces. } \\
\text { Industry concern is with furnace thermal stability and maintenance cost. }\end{array}$ \\
\hline Ceramics & $\begin{array}{l}\text { Furnace Type: Variety of hearth furnaces and trolley and rotary kilns. } \\
\text { Use fibrous insulating materials to fill gaps between the refractory brick, } \\
\text { some use in walls and ceiling but primary use is refractory brick. } \\
\text { Major concern with fiber usage is mechanical abrasion and lifetime. } \\
\text { Not as concerned with energy savings. }\end{array}$ \\
\hline Steel & $\begin{array}{l}\text { Furnace Type: Rotary reheat, walking beam reheat furnaces and ladle covers. } \\
\text { Currently use fibrous modules in the ceiling of the rotary kiln, throughout the } \\
\text { walking beam furnace and on the ladle covers. Concerned with accidental } \\
\text { mechanical damage of fibrous insulating materiais in other high temperature } \\
\text { steel making processes. }\end{array}$ \\
\hline Brass & $\begin{array}{l}\text { Furnace Type: Large rectangular and rotary reheat furnace. } \\
\text { Fibrous insulation is used in the large rectangular reheat furnace and in the } \\
\text { ceiling of the rotary reheat furnace. Though not currently utilized, it could } \\
\text { also be used on the ladle covers. }\end{array}$ \\
\hline
\end{tabular}


B. Interviews with Manufacturers

\begin{tabular}{|l|l||}
\hline Company Name & \multicolumn{1}{|c|}{ Relevant Information Obtained } \\
\hline Geneva Steel & $\begin{array}{l}\text { They have several coke furnaces }\left(2200 \text { to } 240^{\circ} \mathrm{F}\right) \text {, a blast furnace } \\
\left(2500 \text { to } 2600^{\circ} \mathrm{F}\right) \text { and an open hearth furmace }\left(2800^{\circ} \text { to } 3000^{\circ} \mathrm{F}\right) \text {. }\end{array}$ \\
\hline Kaiser Aluminum & $\begin{array}{l}\text { Low density fiber currently used in roof of top charged melting furnaces } \\
\left(2100 \text { to } 2500^{\circ} \mathrm{F}\right) \text {. Ocher possible applications; top loading hormogenizing } \\
\text { furnaces }\left(1000 \text { to } 1100^{\circ} \mathrm{F}\right) \text { and annealing furnaces }\left(800 \text { to } 900^{\circ} \mathrm{F}\right) .\end{array}$ \\
\hline
\end{tabular}

\section{Interviews with Technical Resource People}

\begin{tabular}{|l|l|}
\hline $\begin{array}{l}\text { Person } \\
\text { Refident, } \\
\text { Refractory Sales }\end{array}$ & $\begin{array}{l}\text { Applications for refractory insulating fibers. Fiber condition after usage. } \\
\text { Contacts in the industries using fiber insulation. }\end{array}$ \\
\hline $\begin{array}{l}\text { Steel Plant } \\
\text { Refractories } \\
\text { Engineer }\end{array}$ & $\begin{array}{l}\text { Applications for refractory fibers in Steel Plant } \\
\text { Description of fiber conditions after continuous use. }\end{array}$ \\
\hline
\end{tabular}




\section{SELECTION OF REPRESENTATIVE REFRACTORY INSULATING FIBERS FOR EVALUATION}

\subsection{Rationale for Fiber Selection}

The continuous operating temperatures, trade names, manufacturers, and chemical compositions of the refractory fibers currently in use are shown in Table 3.2 of Section 3. All of these fibers contain alumina $\left(\mathrm{Al}_{2} \mathrm{O}_{3}\right)$ and silica $\left(\mathrm{SiO}_{2}\right)$. Some fibers have significant amounts of either chromia $\left(\mathrm{Cr}_{2} \mathrm{O}_{3}\right)$ or zirconia $\left(\mathrm{ZrO}_{2}\right)$. Trace amounts of other oxides are not considered here. Some fibers are polycrystalline as received and some fibers are vitreous as received. There is a general, but not exact, correlation of continuous service temperature with alumina content for fibers containing only alumina and silica. The polycrystalline fibers have higher continuous service temperatures than the vitreous fibers. Therefore, fibers were examined over a range of alumina and silica contents. Additions of either chromia or zirconia to the fibers appears to increase the continuous useful temperature above that which would be expected based on the alumina/silica ratio. Therefore, the effects of additions of either chromia or zirconia were investigated.

The specific compositions chosen (therefore the continuous service temperatures) should represent fibers that are widely used that are either costly to replace or are at the extreme of fiber use temperatures. The distribution of refractory fiber applications with specified continuous service temperatures is shown in Figure 4.1. The majority of applications are for fibers with continuous service temperatures of between 2300 and $2400^{\circ} \mathrm{F}$. Therefore, two fibers were chosen with this continuous service temperature. One, Kaowool 2600, contains only alumina and silica and the other, Kaowool ZR, contains alumina, silica, and zirconia. A fiber with a $2600^{\circ} \mathrm{F}$ continuous service temperature, Cerachrome, was chosen because it contains alumina, silica, and chromia. The two highest continuous service temperature fibers at $2800^{\circ} \mathrm{F}$, Saffil Alumina, and $3000^{\circ} \mathrm{F}$, Fibermax, were chosen because developing a higher continuous service temperature fiber is one of the objectives of this project. Fiber names, compositions, and continuous service temperatures for the selected fibers are shown in Table 4.1.

\subsection{Purchase of Materials}

One box each of the Saffil Alumina, Fibermax, Kaowool 2600, and Kaowool ZR was purchased from a local distributor. The Cerachrome was obtained directly from Manville. 
Figure 4.1 Refractory Fiber Usage by Application Temperature

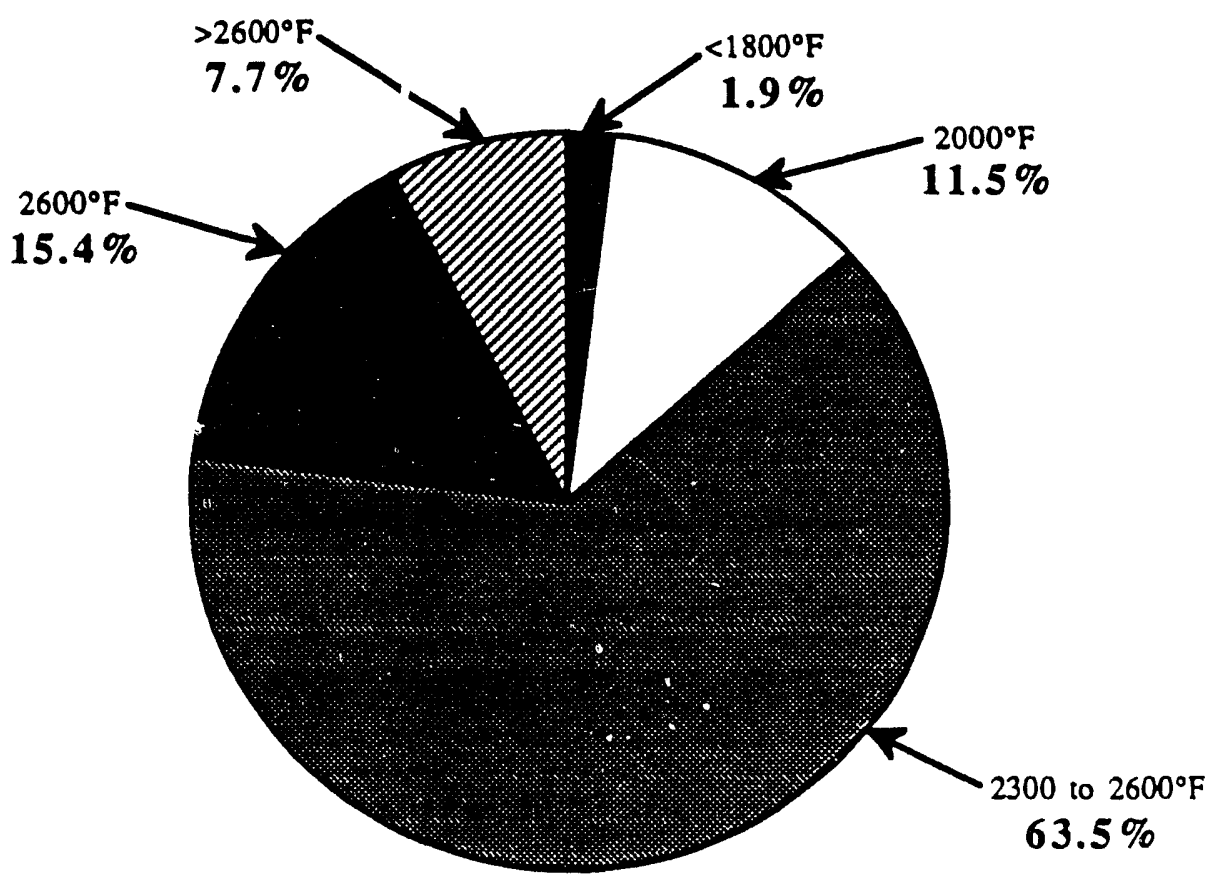

Table 4.1 Fibers Selected for Evaluation

\begin{tabular}{||l|c|c|c|c|c|c|}
\hline \multicolumn{1}{|c|}{ FIBER } & \multicolumn{3}{|c|}{ COMPOSITION, Oxides of } & Continuous use Temperature \\
\hline Kaowool 2600 (Vitreous) & 52 & 48 & - & - & 2300 \\
\hline Kaowool ZR (Vitreous) & 34 & 46 & 20 & -- & 2400 \\
\hline Cerachrome (Vitreous) & 42.5 & 55 & - & 2.5 & 2600 \\
\hline $\begin{array}{l}\text { Saffil Alumina } \\
\text { (Polycrystalline) }\end{array}$ & 96 & 4 & -- & -- & 2800 \\
\hline Fibermax (Polycrystalline) & 72 & 27 & - & -- & 3000 \\
\hline
\end{tabular}




\section{THERMAL AND PHYSICAL PERFORMANCE AND CHARACTERIZATION OF SELECTED FIBERS}

The five fibers selected for evaluation were all heat treated at a constant temperature for controlled time periods and measured for thermal and physical characteristics. The test samples were prepared so that the shrinkage or dimensional changes and the thermal conductivity could be measured on the same piece. Crystalline phase composition by $\mathrm{x}$-ray diffraction analysis and the microstructural analysis by electron microscopy were performed on smaller companion pieces, heat treated at the same time as the larger thermal conductivity samples.

The heat treatment temperature was set at $2600^{\circ} \mathrm{F}$ for all five materials. The heat treatment times initially chosen were $4 \mathrm{~h}$ and $24 \mathrm{~h}$. After the evaluation of the fibers at these initial test times, an additional heat treatment was conducted for $168 \mathrm{~h}(7 \mathrm{~d})$.

\subsection{Test Sample Preparation}

Three fibers, Kaowool 2600, Kaowool ZR, and the Cerachrome, were received in blanket form (nominal $8 \mathrm{lb} / \mathrm{ft}^{3}, 1$ in. thick). Because the thermal conductivity of refractory fiber blankets is related to the density of the blanket, similar density test pieces were obtained by cutting the blanket into a number of $12 \times 12$ in. pieces. The samples to be tested were selected by picking pieces within $5 \mathrm{~g}$ of the same weight. The companion pieces for $\mathrm{x}$-ray and microscopy were cut $3 \times 2$ in. from the blanket near the same area as the large samples.

Two fibers, Fibermax and Saffil, were received in bulk form. Similar density samples of each fiber were prepared for the thermal treatments by dispersing $410 \mathrm{~g}$ of fiber and $8 \mathrm{~g}$ of cooked starch in 4 gal of water. The mixture was dewatered by free-draining in a $14 \times 14$ in. board former. The formed wet board was pressed to 1 in. thick and dried. The dried boards were trimmed to $12 \times 12$ in. for the thermal conductivity testing and the edge trim was saved for heat treatment for the $x$-ray and microscopic evaluations.

\subsection{Heat Treatment}

Each $12 \times 12$ in. fiber sample, along with a companion $3 \times 2$ in. piece, was placed in a preheated, electrically heated furnace. The furnace temperature was controlled at a set point temperanure of $2600^{\circ} \mathrm{F}$. Each sample set was placed in the furnace for one of the set times of $4 \mathrm{~h}, 24 \mathrm{~h}$, or $168 \mathrm{~h}$. One set of samples was retained with no heat treatment for as-received evaluations. The 4 and $24 \mathrm{~h}$ samples were heat treated before being tested for thermal and physical characteristics. After these samples and the as-received samples were evaluated, additional samples were heat treated at $168 \mathrm{~h}$ and evaluated. 


\subsection{Shrinkage at $2600^{\circ} \mathrm{F}$}

The physical dimensions of each test sample were measured before and after heat treatment at $2600^{\circ} \mathrm{F}$. The shrinkage of each fiber blanket was determined by comparing ihe before and after measurements. The shrinkage results are plotted in Figure 5.1, where the length and width shrinkages are averaged, and shown in Table 5.1. The major portion of the shrinkage occurred within the first four hours of heat treatment. The two higher temperature fibers, Fibermax and Saffil, exhibited the lowest extent of shrinkage, of $\sim 2 \%$. The three other fibers, Kaowool 2600 , Kaowool ZR, and Cerachrome exhibited more shrinkage, up to $12 \%$. The $12 \times 12$ in. heat treated test samples were retained for thermal conductivity testing. The $3 \times 2$ in. heat treated test samples were retained for $\mathrm{x}$-ray diffraction and electron microscopic evaluation.

Figure 5.1 Linear Shrinkage of Fiber Felts Heat Treated at $2600^{\circ} \mathrm{F}$

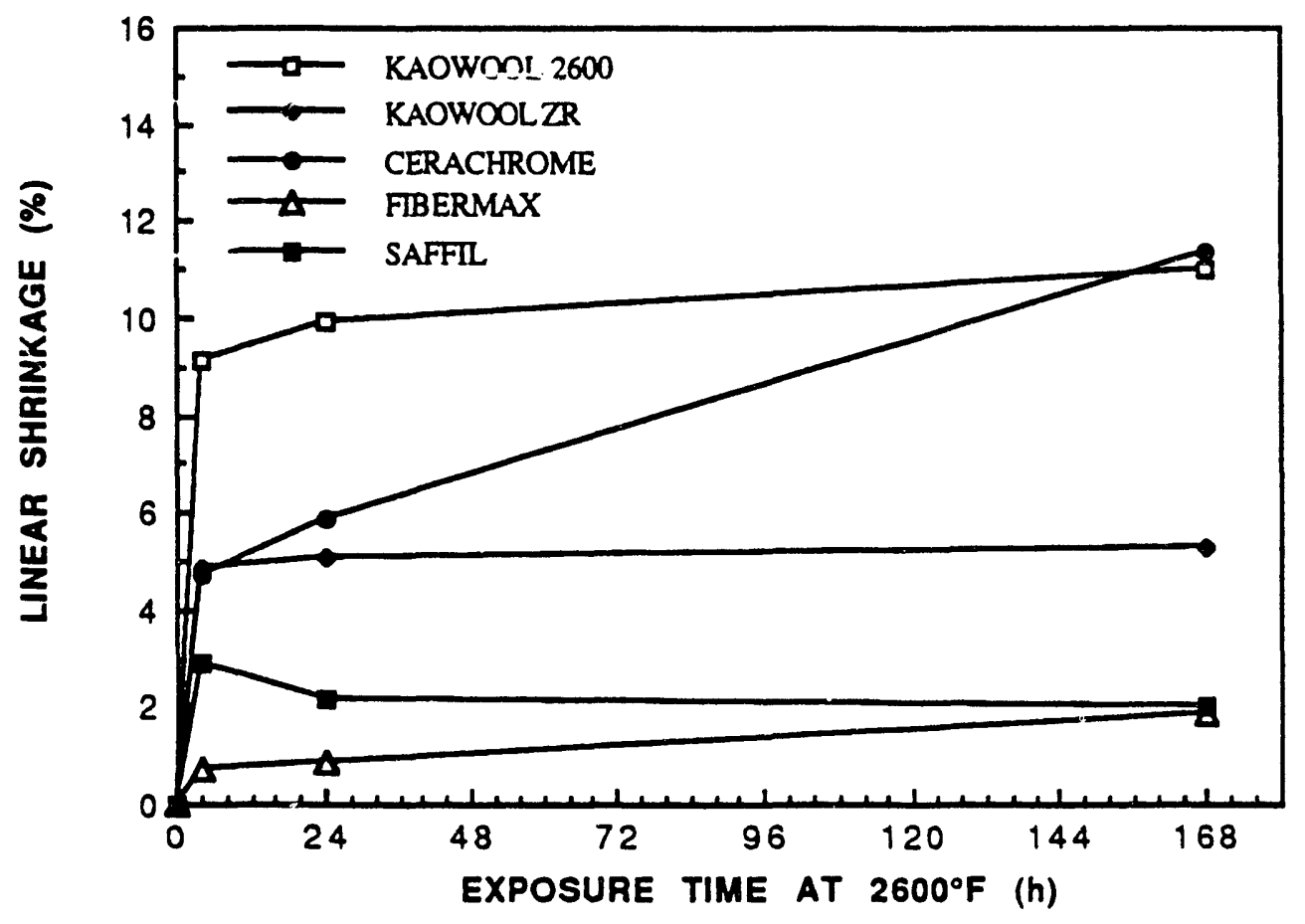




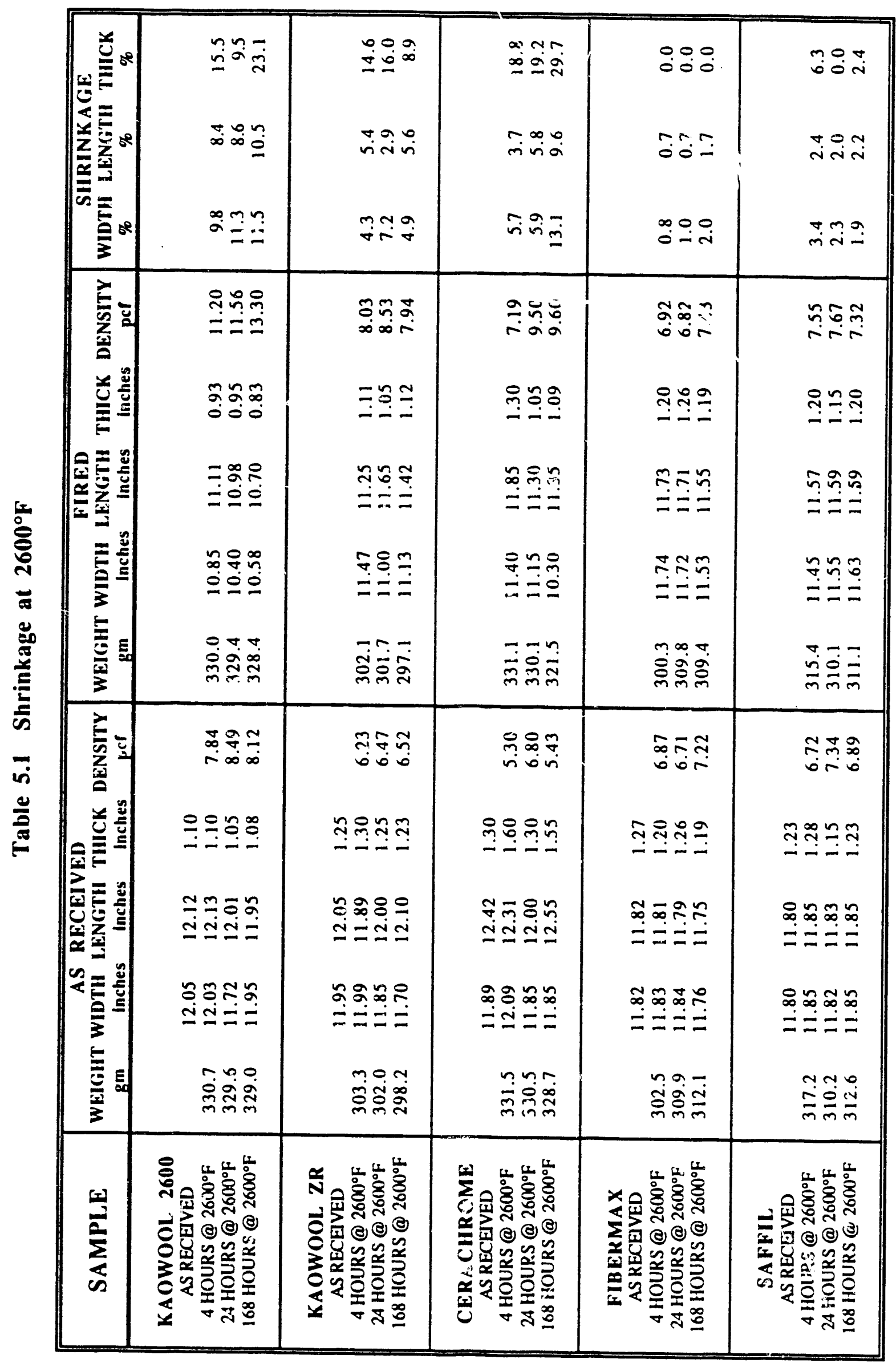




\subsection{Thermal Conductivity}

The apparent thermal conductivity of the heat treated samples and the as-received samples of each of the five fiber materials was measured at $1000^{\circ} \mathrm{F}$ mean on a High-Temperature Heat Flow Meter using the test method specified in ASTM C-518. The as-received, $4 \mathrm{~h}$, and $24 \mathrm{~h}$ heat treatment samples were tested at thicknesses such that the test densities (within each fiber type) were nearly the same. For example, the Kaowool 2600 samples were tested at $11.6 \mathrm{lb} / \mathrm{ft}^{3}$, while the Kaowool $\mathrm{ZR}$ samples were tested at $9.0 \mathrm{lb} / \mathrm{ft}^{3}$. Because the thermal conductivity of refractory fiber blankets changes with changes in density, the adjustment to equal sample density for the thermal conductivity testing allows the evaluation of the effect of heat treating of the fibers themselves rather than the effect of density increases because of shrinkage. The $7 \mathrm{~d}(168 \mathrm{~h})$ test samples were heat treated after all of the other samples were evaluated for shrinkage and thermal conductivity. Several of the $168 \mathrm{~h}$ samples could not be tested at the same density as the other pieces of the same fiber. The after heat treatment thickness of the $168 \mathrm{~h}$ pieces was such that the density was significantly higher than the previously tested pieces. For example, the thermal conductivity test on the Kaowool 2600 was performed at a test thickness of $0.72 \mathrm{in}$., a density of $15.3 \mathrm{lb} / \mathrm{ft}^{3}$. The as-fired thickness was $0.83 \mathrm{in}$., a density of $13.3 \mathrm{lb} / \mathrm{ft}^{3}$, the minimum density possible for the thermal conductivity test. The initially heat treated samples of Kaowool 2600 were tested at a density of $11.6 \mathrm{lb} / \mathrm{ft}^{3}$. Noting the exceptions of these anomolies, the results of the thermal conductivity testing at "equal" density are shown in Table 5.2 and plotted in Figure 5.2.

The apparent thermal conductivities of all of the heat treated samples were higher than the asreceived samples at the same test density. The increase in thermal conductivity ranged from $10 \%$ for the Fibermax to $35 \%$ for the Kaowool 2000 . The thermal conductivity test results were incorporated into the calculation of potential energy savings. 
Table 5.2 Apparent Thermal Conductivity at $1000^{\circ} \mathrm{F}$ Mean

\begin{tabular}{|c|c|c|c|c|c|c|c|}
\hline SAMPLE & $\begin{array}{c}\text { WIDTH } \\
\text { (in.) }\end{array}$ & $\begin{array}{l}\text { FIRED } \\
\text { LENGTH } \\
(\text { in. })\end{array}$ & $\begin{array}{c}\text { THICK } \\
\text { (In.) }\end{array}$ & $\begin{array}{c}\text { TEST } \\
\text { THICK } \\
(\text { In.) }\end{array}$ & $\begin{array}{l}\text { FIRED } \\
\text { WEIGHT } \\
(\mathrm{g})\end{array}$ & $\begin{array}{c}\text { TEST } \\
\text { DENSITY } \\
{\mathrm{Ib} / \mathrm{ft}^{3}}^{3}\end{array}$ & $\begin{array}{l}\text { APPARENT THER.MAL } \\
\text { CONDUCTIVITY } \\
\text { BTU.In./h- }-\mathrm{ft}^{2} \cdot{ }^{\circ} \mathrm{F}\end{array}$ \\
\hline $\begin{array}{c}\text { KAOWOOL } 2600 \\
\text { AS RECEIVED } \\
4 \mathrm{~h} @ 2600^{\circ} \mathrm{F} \\
24 \mathrm{~h} @ 2600^{\circ} \mathrm{F} \\
168 \mathrm{~h} @ 2600^{\circ} \mathrm{F}\end{array}$ & $\begin{array}{l}12.05 \\
10.85 \\
10.40 \\
10.58\end{array}$ & $\begin{array}{l}12.12 \\
11.11 \\
10.98 \\
10.70\end{array}$ & $\begin{array}{l}1.10 \\
0.93 \\
0.95 \\
0.83\end{array}$ & $\begin{array}{l}0.75 \\
0.90 \\
0.95 \\
0.72\end{array}$ & $\begin{array}{l}332.2 \\
330.0 \\
329.4 \\
328.4\end{array}$ & $\begin{array}{l}11.5 \\
11.6 \\
11.6 \\
15.3\end{array}$ & $\begin{array}{l}0.65 \\
0.84 \\
0.88 \\
0.68\end{array}$ \\
\hline $\begin{array}{c}\text { KAOWOOL ZR } \\
\text { AS RECEIVED } \\
4 \mathrm{~h} @ 2600^{\circ} \mathrm{F} \\
24 \mathrm{~h} @ 2600^{\circ} \mathrm{F} \\
168 \mathrm{~h} @ 2600^{\circ} \mathrm{F}\end{array}$ & $\begin{array}{l}11.95 \\
11.47 \\
11.00 \\
11.13\end{array}$ & $\begin{array}{l}12.05^{\circ} \\
11.25 \\
11.65 \\
11.42\end{array}$ & $\begin{array}{l}1.25 \\
1.11 \\
1.05 \\
1.12\end{array}$ & $\begin{array}{l}0.90 \\
1.00 \\
1.00 \\
1.00\end{array}$ & $\begin{array}{l}305.1 \\
302.1 \\
301.7 \\
297.1\end{array}$ & $\begin{array}{l}9.0 \\
8.9 \\
9.0 \\
8.9\end{array}$ & $\begin{array}{l}0.71 \\
0.83 \\
0.83 \\
0.77\end{array}$ \\
\hline $\begin{array}{c}\text { CERACHROME } \\
\text { AS RECEIVED } \\
4 \mathrm{~h} @ 2600^{\circ} \mathrm{F} \\
24 \mathrm{~h} @ 2600^{\circ} \mathrm{F} \\
168 \mathrm{~h} @ 2600^{\circ} \mathrm{F}\end{array}$ & $\begin{array}{l}11.89 \\
11.40 \\
11.15 \\
10.30\end{array}$ & $\begin{array}{l}12.42 \\
11.85 \\
11.30 \\
11.35\end{array}$ & $\begin{array}{l}1.30 \\
1.30 \\
1.05 \\
1.09\end{array}$ & $\begin{array}{l}0.90 \\
1.00 \\
1.05 \\
1.09\end{array}$ & $\begin{array}{l}333.5 \\
331.1 \\
330.1 \\
321.5\end{array}$ & $\begin{array}{l}9.6 \\
9.3 \\
9.5 \\
9.6\end{array}$ & $\begin{array}{l}0.71 \\
0.78 \\
0.83 \\
0.82\end{array}$ \\
\hline $\begin{array}{c}\text { FIBER.MAX } \\
\text { AS RECEIVED } \\
4 \mathrm{~h} @ 2600^{\circ} \mathrm{F} \\
24 \mathrm{~h} @ 2600^{\circ} \mathrm{F} \\
168 \mathrm{~h} @ 2600^{\circ} \mathrm{F}\end{array}$ & $\begin{array}{l}11.82 \\
11.74 \\
11.72 \\
11.53\end{array}$ & $\begin{array}{l}11.82 \\
11.73 \\
11.71 \\
11.55\end{array}$ & $\begin{array}{l}1.27 \\
1.20 \\
1.26 \\
1.19\end{array}$ & $\begin{array}{l}1.27 \\
1.20 \\
1.26 \\
1.19\end{array}$ & $\begin{array}{l}309.2 \\
300.3 \\
309.8 \\
309.4\end{array}$ & $\begin{array}{l}6.6 \\
6.9 \\
6.8 \\
7.4\end{array}$ & $\begin{array}{l}0.71 \\
0.78 \\
0.79 \\
0.78\end{array}$ \\
\hline $\begin{array}{c}\text { SAFFIL } \\
\text { AS RECEIVED } \\
4 \mathrm{~h} @ 2600^{\circ} \mathrm{F} \\
24 \mathrm{~h} @ 2600^{\circ} \mathrm{F} \\
168 \mathrm{~h} @ 2600^{\circ} \mathrm{F}\end{array}$ & $\begin{array}{l}11.80 \\
11.45 \\
11.55 \\
11.63\end{array}$ & $\begin{array}{l}11.80 \\
11.57 \\
11.59 \\
11.59\end{array}$ & $\begin{array}{l}1.23 \\
1.20 \\
1.15 \\
1.20\end{array}$ & $\begin{array}{l}1.23 \\
1.20 \\
1.15 \\
1.20\end{array}$ & $\begin{array}{l}316.4 \\
315.4 \\
310.1 \\
311.1\end{array}$ & $\begin{array}{l}7.0 \\
7.6 \\
7.7 \\
7.3\end{array}$ & $\begin{array}{l}0.69 \\
0.79 \\
0.77 \\
0.79\end{array}$ \\
\hline
\end{tabular}


Figure 5.2 Thermal Conductivity of Fiber Felts Heat Treated at $2600^{\circ} \mathrm{F}$

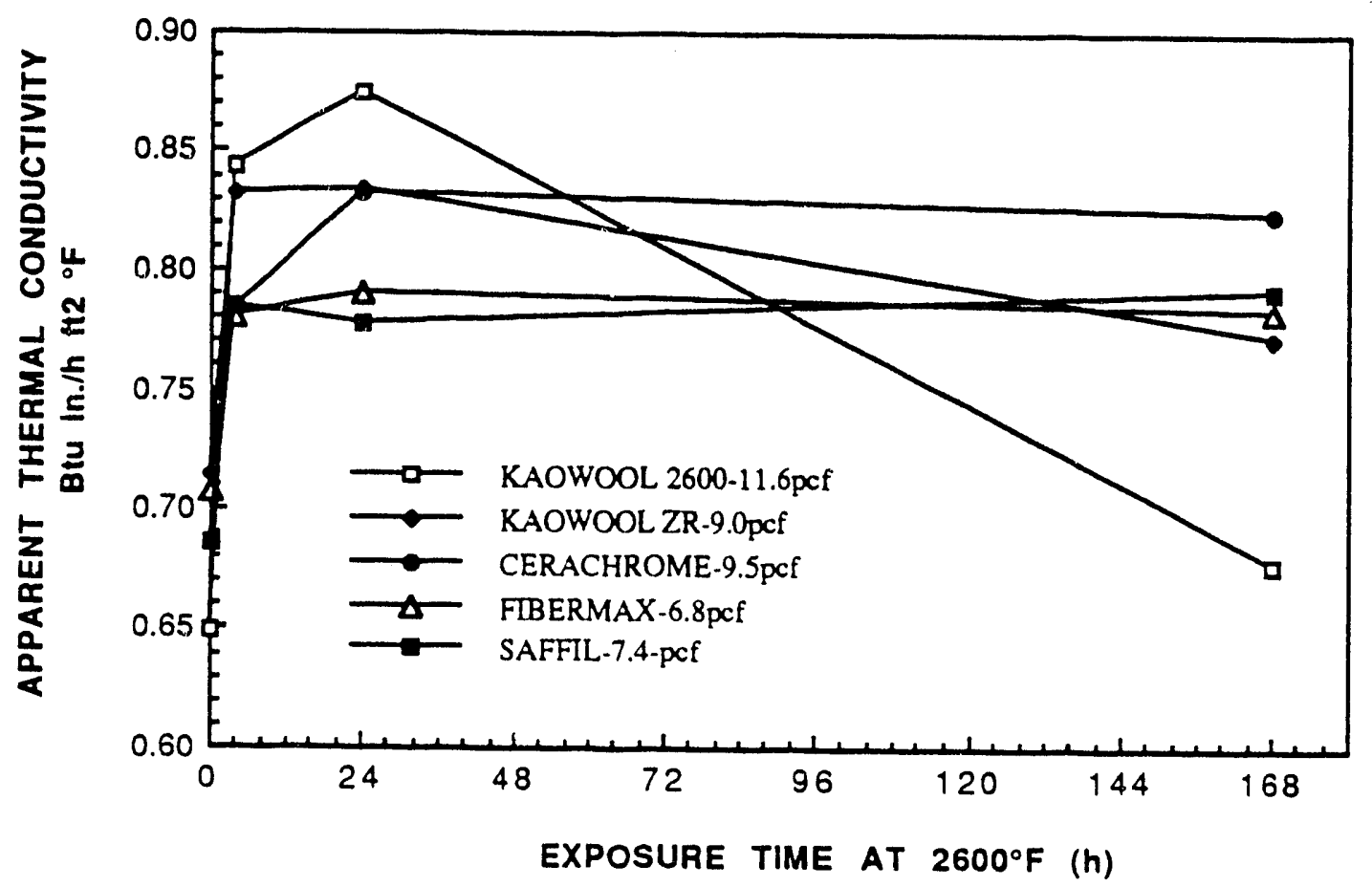

\subsection{Devitrification Studies}

All fibers tested exhibited shrinkage and changes in thermal conductivity. These property changes resulted from microstructural changes in the fibers. Devitrification was the microstructural change for the initially vitreous fibers; phase transformations and grain growth were the microstructural changes for the initially crystalline fibers. The experimental studies to characterize the timetemperature microstructural evolution for the fibers tests are summarized in this section.

The $3 \times 2$ in. samples heat treated at $2600^{\circ} \mathrm{F}$ for 4,24 , and $168 \mathrm{~h}(7 \mathrm{~d})$ were used to bracket heating times and temperatures for a detailed devitrification study. Analyses of the phases present before and after heating at $2600^{\circ} \mathrm{F}$ for $168 \mathrm{~h}$ are summarized in Table 5.3. Typical $\mathrm{x}$-ray diffraction patterns are included in Figure 5.3 for Kaowool ZR, showing the vitreous as-received diffuse pattern and the progressive development of the crystalline phases at $2600^{\circ} \mathrm{F}$ with increasing heat treatment times of 4, 24, and $7 \mathrm{~d}(168 \mathrm{~h})$. X-ray diffraction patterns for all five fibers are included in Appendix A.2. Typical Scanning Electron Microscopy (SEM) views of the developing crystal 
phases in the Kaowool ZR are shown in Figure 5.4. SEM views of all five fibers are included in Appendix A.3.

Table 5.3 Devitrification Products in the Five Selected Fibers Fully Devitrified and As-Received

\begin{tabular}{||l|l|l||}
\hline FIBER & AS-RECEIVED & DEVITRIFIED \\
\hline Kaowool 2600 & Amorphous & $\begin{array}{l}\text { Mullite } \\
\text { Cristobalite }\end{array}$ \\
\hline Kaowool ZR & Amorphous & $\begin{array}{l}\text { Mullite } \\
\text { Cristobalite } \\
\text { t-Zirconia } \\
\text { m-Zirconia } \\
\text { Zircon }\end{array}$ \\
\hline Cerachrome & & $\begin{array}{l}\text { Mullite } \\
\text { Cristobalite }\end{array}$ \\
\hline Saffil & Amorphous & $\begin{array}{l}\text { Corundum } \\
\text { Mullite }\end{array}$ \\
\hline Fibermax & delta-Alumina & Mullite \\
\hline
\end{tabular}

The only difference in the results between the 4 and $24 \mathrm{~h}$ heat treatments for all fibers is in the phases present in the Kaowool ZR. Zircon appears only after the $2600^{\circ} \mathrm{F}$ heat treatment for $168 \mathrm{~h}$. Also, significant shrinkage and changes in thermal conductivity occurred in all samples following the $4 \mathrm{~h}$ heat treatment at $2600^{\circ} \mathrm{F}$. The time and temperature condition of the fiber for the onset of devitrification became the subject of a more detailed investigation.

Samples of the three vitreous fibers; Kaowool 2600, Kaowool ZR, and Cerachrome, were heat treated at $900^{\circ} \mathrm{C}\left(1652^{\circ} \mathrm{F}\right)$ for $3 \mathrm{~h}$ and at $1000^{\circ} \mathrm{C}\left(1832^{\circ} \mathrm{F}\right)$ for $2 \mathrm{~h}$ to determine the onset of devitrification. For both the 900 and $1000^{\circ} \mathrm{C}$ heat treatments each sample weight was $\sim 0.5 \mathrm{~g}$. The samples were cut from the 1 in. thick blankets. The samples were delaminated and stretched into a loose layer of fiber. The samples were placed on a thin layer of the original blanket for the prevention of contamination before being placed inside the furnace at room temperature. The furnace used for the heat-treatment was a Fisher Scientific Isotemp Programmable Furnace, Model 495A. Four fumace parameters can be programmed, namely (a) the heat-up rate, $R_{1}$, (b) the holding time, $t$, (c) the holding temperature, $T$, and (d) the cool-down rate, $R_{2}$. The settings for these parameters were:

\begin{tabular}{ccc} 
Parameter & Set 1 & Set 2 \\
\hline$R_{1}$ & $30^{\circ} \mathrm{C} / \min$ & $30^{\circ} \mathrm{C} / \mathrm{min}$ \\
$t$ & $3 \mathrm{~h}$ & $2 \mathrm{~h}$ \\
$\mathrm{~T}$ & $900^{\circ} \mathrm{C}$ & $1000^{\circ} \mathrm{C}$ \\
$\mathrm{R}_{2}$ & $30^{\circ} \mathrm{C} / \mathrm{min}$ & $30^{\circ} \mathrm{C} / \mathrm{min}$
\end{tabular}


Figure 5.3 X-Ray Diffraction Patterns for Kaowool ZR at Various Heat Treatment Times at $2600^{\circ} \mathrm{F}$

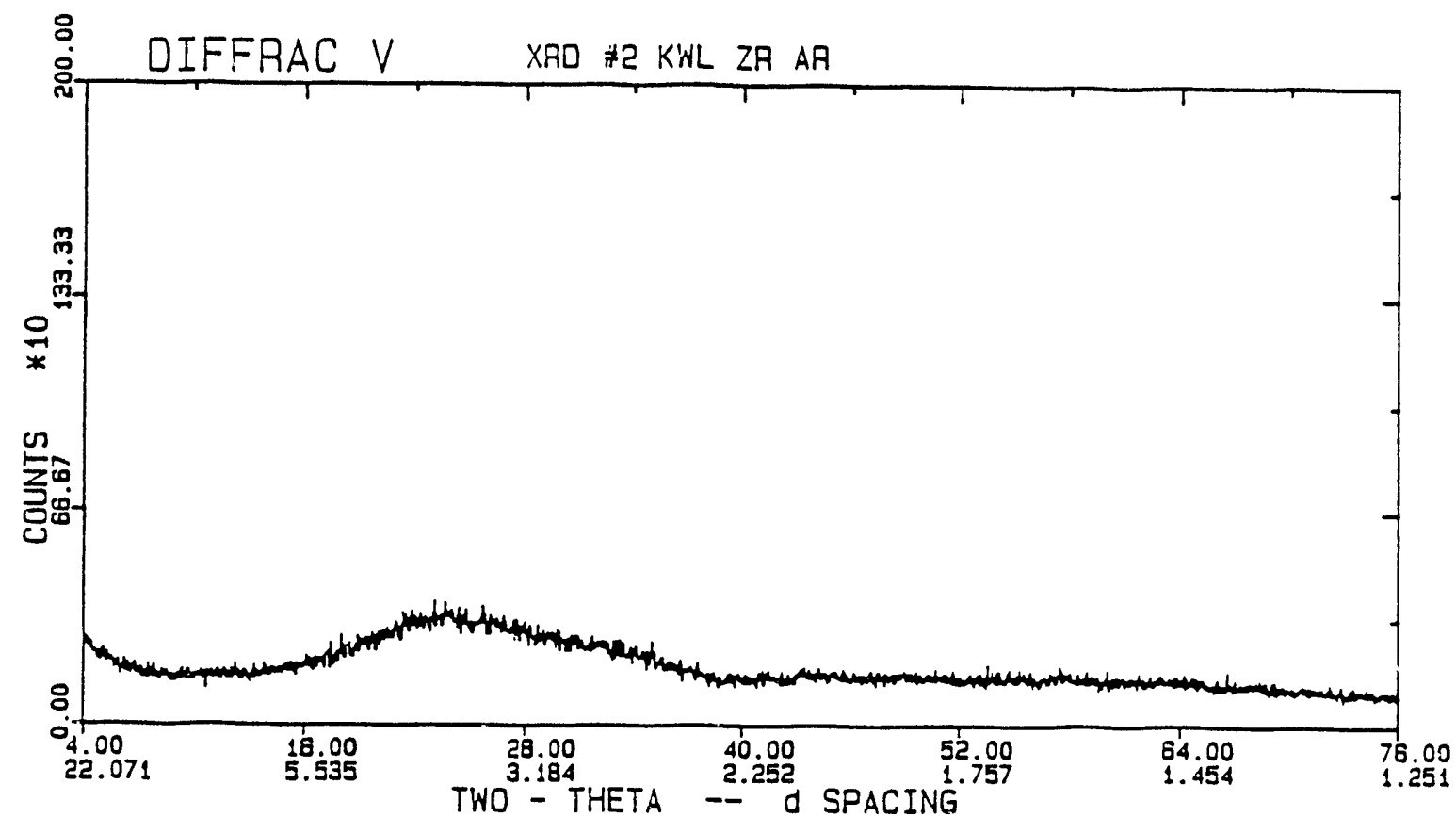

KAOWOOL ZR - AS RECEIVED

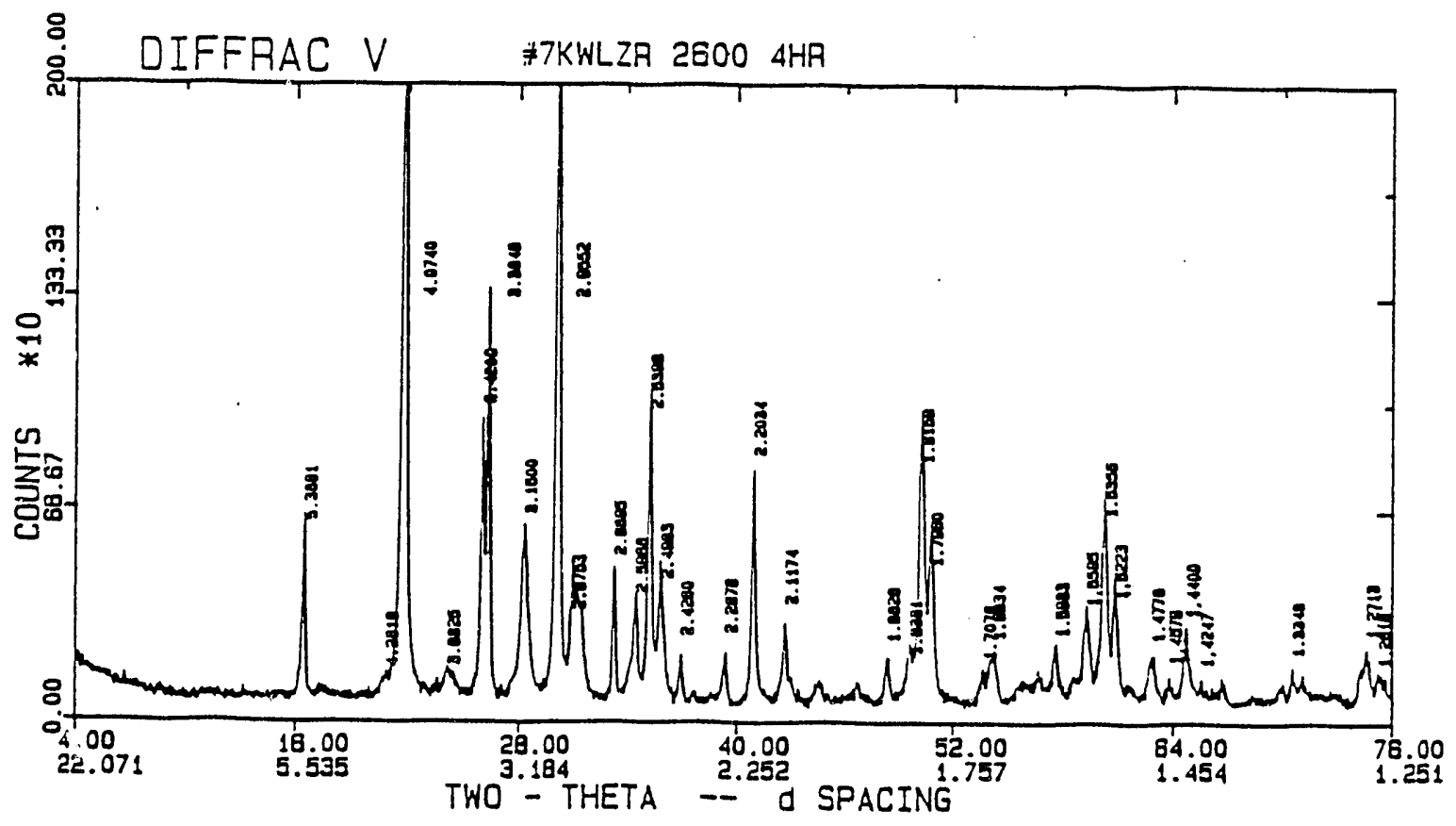

KAOWOOL ZR - AFTER 4 HOURS@ $2600^{\circ} \mathrm{F}$ 
Figure 5.3 X-Ray Diffraction Patterns for Kaowool ZR at Various Heat Treatment Times at $2600^{\circ} \mathrm{F}$ (Continued)

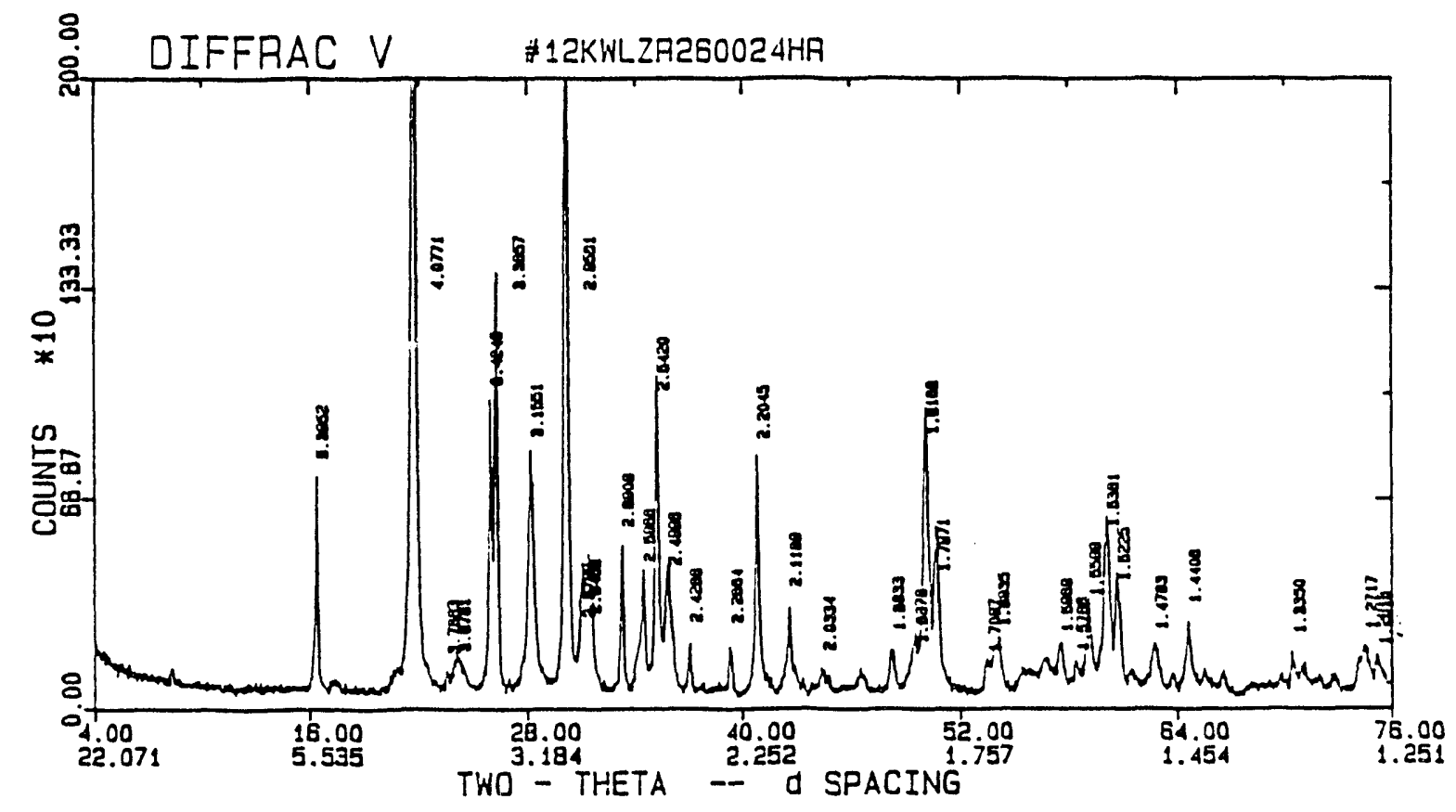

KAOWOOL ZR - AFTER 24 HOURS@ $2600^{\circ} \mathrm{F}$

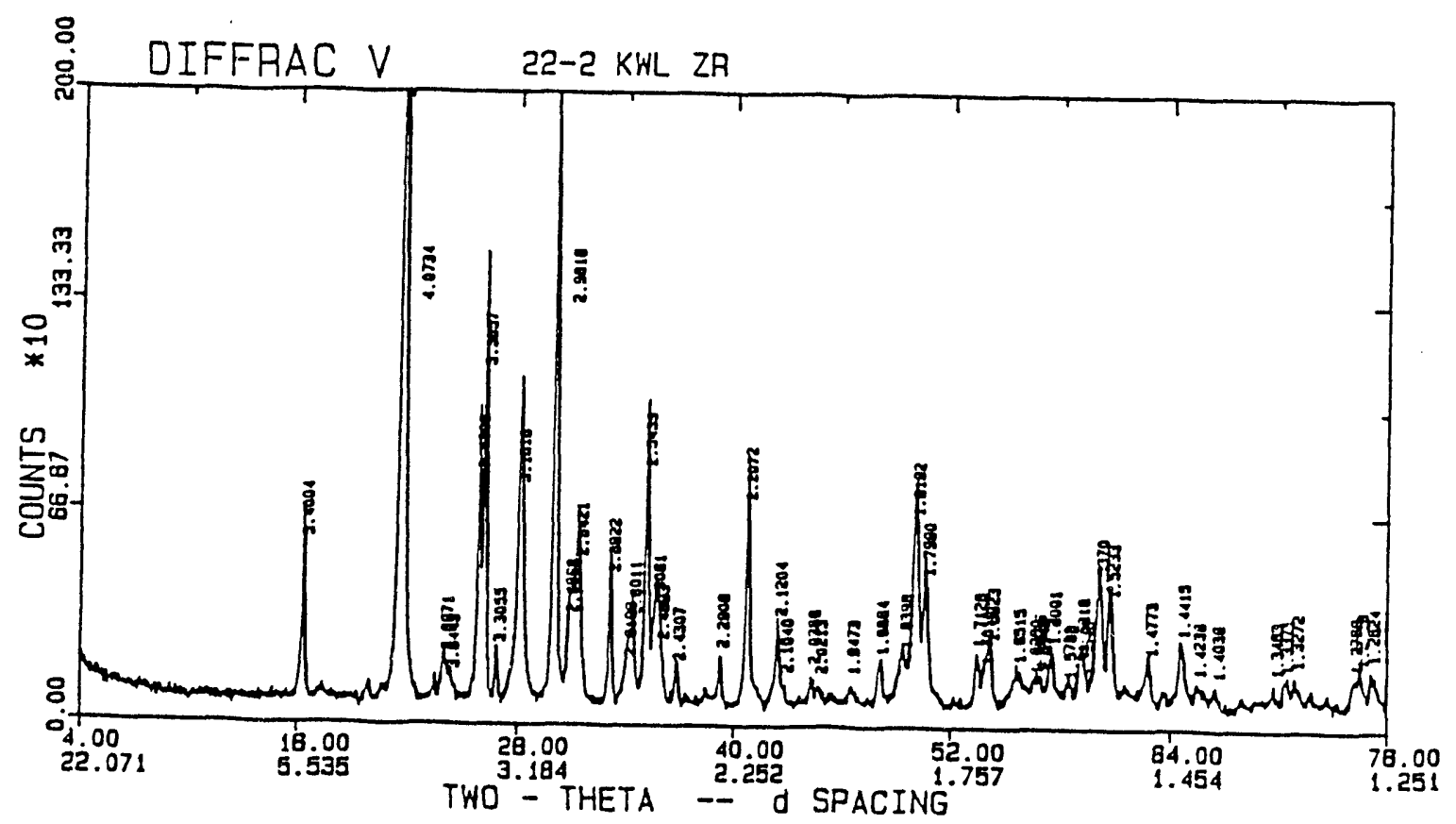

KAOWOOL ZR - AFTER 168 HOURS@ 2600F 
Figure 5.4 SEM Views of Kaowool ZR at Various Heat Treatment Times at $2600^{\circ} \mathrm{F}$
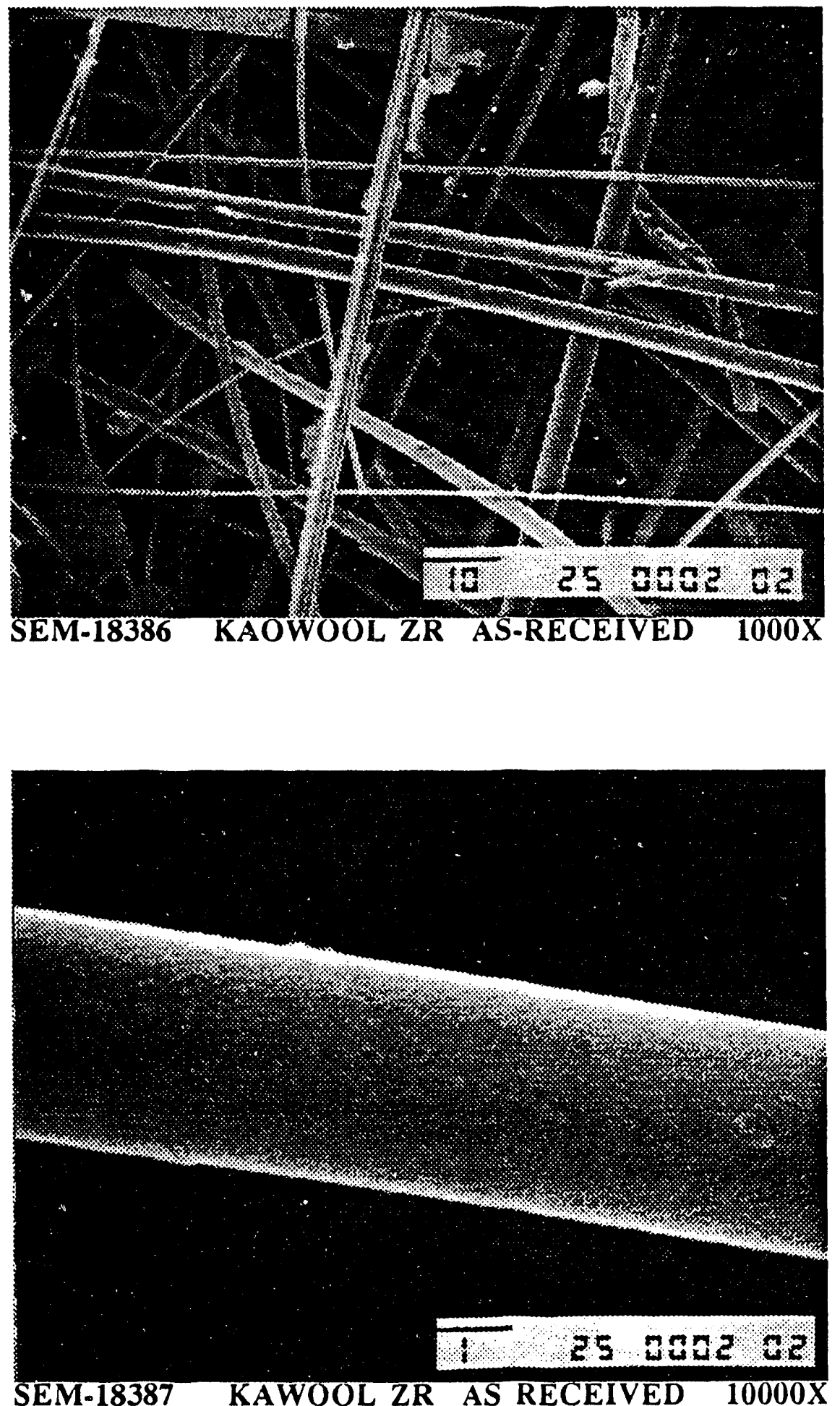
Figure 5.4 SEM Views of Kaowool ZR at Various Heat Treatment Times at $2600^{\circ} \mathrm{F}$ (Continued)
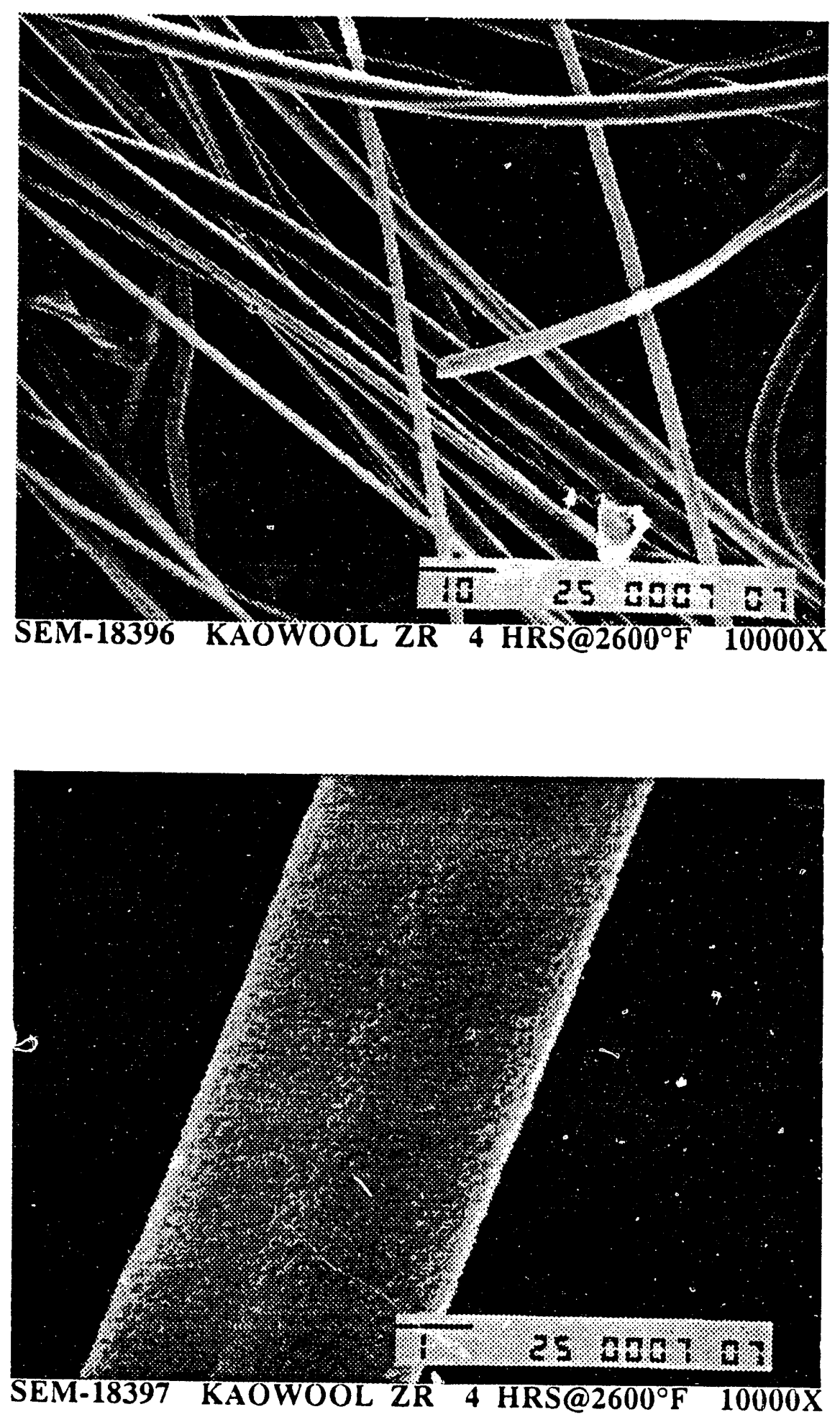
Figure 5.4 SEM Views of Kaowool ZR at Various Heat Treatment Times at $2600^{\circ} \mathrm{F}$ (Continued)
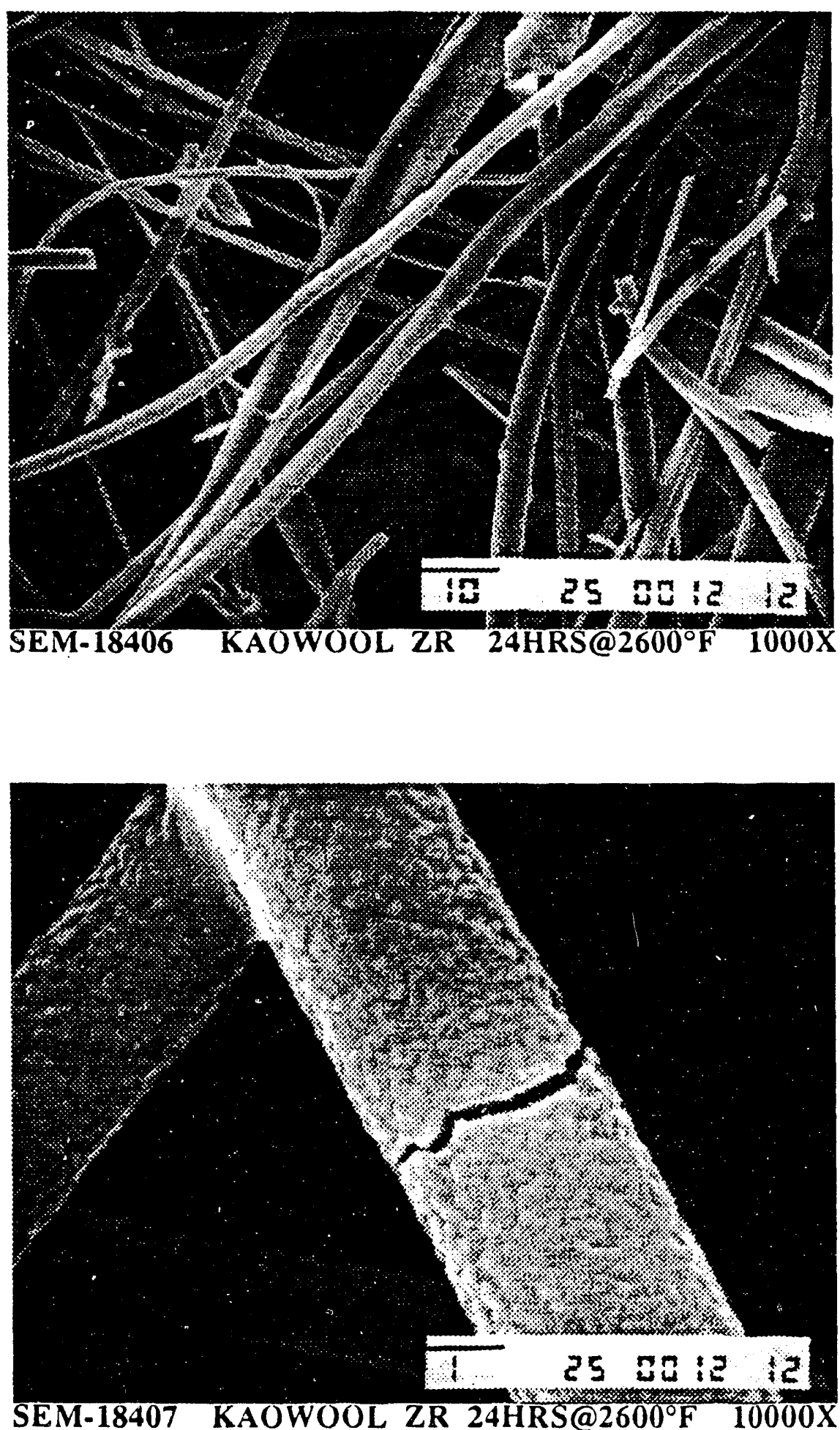
Figure 5.4 SEM Views of Kaowool $\mathrm{ZR}$ at Various Heat Treatment Times at $2600^{\circ} \mathrm{F}$ (Continued)
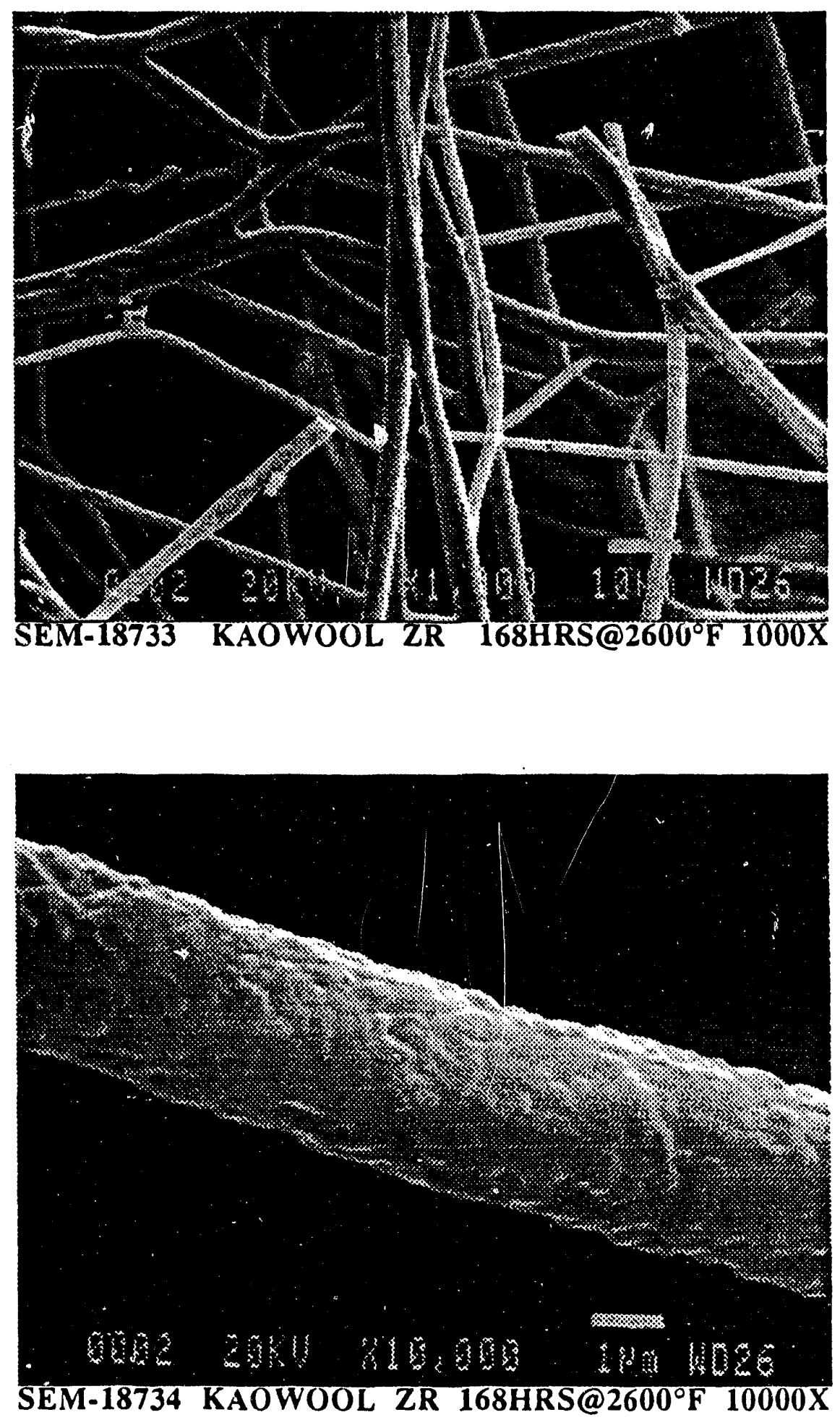
The fiber samples were inserted into the furnace at room temperature. In Set 1, the sample was removed when the furnace temperature reading was dropped to $450^{\circ} \mathrm{C}$, while for Set 2 it was removed at $200^{\circ} \mathrm{C}$. The Set 1 and the Set 2 samples are referred to as the $900^{\circ} \mathrm{C}$ and the $1000^{\circ} \mathrm{C}$ samples, respectively.

All three fibers remained amorphous (vitreous) after heating to $900^{\circ} \mathrm{C}\left(1652^{\circ} \mathrm{F}\right)$ for 3 hours. Devitrification was observed in all three samples after heating to $1000^{\circ} \mathrm{C}\left(1832^{\circ} \mathrm{F}\right)$ for $2 \mathrm{~h}$. Heating times and temperatures for a detailed devitrification study were based on these results. The heating times and temperatures selected for the detailed devitrification study were temperatures of 1800 through $2600^{\circ} \mathrm{F}$ in increments of $200^{\circ} \mathrm{F}$ for times of $15,30,45,60 \mathrm{~s}$ and 10,20 , and $30 \mathrm{~min}$, as shown in Table 5.4

Table 5.4 Heating Times and Temperatures for Detailed Devitrification Study

\begin{tabular}{|c|c|c|c|c|c|c|c|}
\hline${ }^{\circ}$ Time $)$ & 15 s & 30 s & 45 s & 60 s & 10 min & 20 min & 30 min \\
\hline 1800 & $\mathrm{x}$ & $\mathrm{x}$ & $\mathrm{x}$ & $\mathrm{x}$ & $\mathrm{x}$ & $\mathrm{x}$ & $\mathrm{x}$ \\
\hline 2000 & $\mathrm{x}$ & $\mathrm{x}$ & $\mathrm{x}$ & $\mathrm{x}$ & $\mathrm{x}$ & $\mathrm{x}$ & $\mathrm{x}$ \\
\hline 2200 & $\mathrm{x}$ & $\mathrm{x}$ & $\mathrm{x}$ & $\mathrm{x}$ & $\mathrm{x}$ & $\mathrm{x}$ & $\mathrm{x}$ \\
\hline 2400 & $\mathrm{x}$ & $\mathrm{x}$ & $\mathrm{x}$ & $\mathrm{x}$ & $\mathrm{x}$ & $\mathrm{x}$ & $\mathrm{x}$ \\
\hline 2600 & $\mathrm{x}$ & $\mathrm{x}$ & $\mathrm{x}$ & $\mathrm{x}$ & $\mathrm{x}$ & $\mathrm{x}$ & $\mathrm{x}$ \\
\hline
\end{tabular}

The furnace used was an electric indirect resistance furnace, Deltech, Inc., Model DT-31-RS-OS MODE-EMS. The construction is that of a cylindrical body, open at the bottom to accept the hearth. The hearth can be raised and lowered with an electronic control unit that controls the overall heating process. The fiber samples were of two standard sizes for each of the three amorphous fibers, corresponding to the short and the long durations of heat-treatment. Short duration here means the time of heat-treatment is not more than $1 \mathrm{~min}$, i.e., the $15,30,45$, and the $60 \mathrm{~s}$ samples. Long duration refers to the longer trtatment times of 10,20 , and $30 \mathrm{~min}$. The sizes for the two sets of treatment are:

Shor Duration

$2.5 \mathrm{~cm} \times 7.5 \mathrm{~cm} \times 1 / 4 \mathrm{in}$.
Long Duration

$2.5 \mathrm{~cm} \times 7.5 \mathrm{~cm} \times 1 / 3 \mathrm{in}$.

In addition, the short duration samples were loosened before being placed inside the furnace so as to reduce the effect of insulation of the interior portion of the fiber by the outer layer. The timetemperature heat-treatment tests for all fibers were as shown in Table 5.4, except for the short duration Kaowool 2600 samples at $2400^{\circ} \mathrm{F}$, which were not obtained because of a malfunctioning 
furnace. The samples were inserted into and then removed after the specified time from the hot furnace set at the specified temperature. The short duration samples were inserted into the furnace individually, i.e., one sample of each fiber at a time. The long duration fibers were inserted three samples each time, one each of Kaowool 2600, Kaowool ZR, and Cerachrome. All samples were set on pcrous zirconia refractory plates, which were heated along with the fiber.

The procedure for heat treating the samples was as follows:

1. Set fumace temperature at desired set point and allow to stabilize

2. Lower the hearth

3. Using long handle tongs, place the zirconia sample holding plate onto the hearth

4. Raise the hearth up into the heated furnace

5. Lower the hearth at the desired time

6. Remove the zirconia plate with the sample to an adjacent stationary hearth

7. Return the empty furnace hearth to the furnace

8. Remove the sample from the zirconia plate for cooling to room temperature.

The time of heat-treatment entered in Table 5.4 is the time of Step 5 above. The samples cool to room temperature in a matter of seconds after being removed (Step 8 ) from the hot zirconia plate.

The results of the time-temperature devitrification studies are summarized in Tables 5.5 through 5.7. The crystalline phases identified by $x$-ray diffraction are abbreviated in these tables as:

Mullite $=\mathrm{M}$
Cristobalite $=\mathrm{C}$
$\mathrm{t}$-Zirconia $=\mathrm{Z}$
$\mathrm{m}$-Zirconia $=\mathrm{mZ}$

Table 5.5 Crystalline Phases in the Devitrification of Kaowool 2600

\begin{tabular}{||c|c|c|c|c|c|c|c|}
\hline \multirow{2}{*}{$\operatorname{TEMP}\left({ }^{\circ} \mathrm{F}\right)$} & \multicolumn{7}{|c|}{ TIME } \\
\cline { 2 - 8 } & $15 \mathrm{~s}$ & $30 \mathrm{~s}$ & $45 \mathrm{~s}$ & $60 \mathrm{~s}$ & $10 \mathrm{~min}$ & $20 \mathrm{~min}$ & $30 \mathrm{~min}$ \\
\hline 2600 & $\mathrm{M}$ & $\mathrm{M}$ & $\mathrm{M}$ & $\mathrm{M}$ & $\mathrm{M}$ & $\mathrm{M}$ & $\mathrm{M}, \mathrm{C}$ \\
\hline 2400 & $\mathrm{M}$ & $\mathrm{M}$ & $\mathrm{M}$ & $\mathrm{M}$ & $\mathrm{M}$ & $\mathrm{M}$ & $\mathrm{M}$ \\
\hline 2200 & $\mathrm{M}$ & $\mathrm{M}$ & $\mathrm{M}$ & $\mathrm{M}$ & $\mathrm{M}$ & $\mathrm{M}$ & $\mathrm{M}$ \\
\hline 2000 & nil & $\mathrm{M}$ & $\mathrm{M}$ & $\mathrm{M}$ & $\mathrm{M}$ & $\mathrm{M}$ & $\mathrm{M}$ \\
\hline 1800 & nil & nil & nil & nil & $\mathrm{M}$ & $\mathrm{M}$ & $\mathrm{M}$ \\
\hline
\end{tabular}


Table 5.6 Crystalline Phases in the Devitrification of Kaowool ZR

\begin{tabular}{|c|c|c|c|c|c|c|c|}
\hline \multirow[b]{2}{*}{$\operatorname{TEMP}\left({ }^{\circ} \mathrm{F}\right)$} & \multicolumn{7}{|c|}{ TIME } \\
\hline & $15 \mathrm{~s}$ & $30 \mathrm{~s}$ & $45 \mathrm{~s}$ & $60 \mathrm{~s}$ & $10 \mathrm{~min}$ & $20 \mathrm{~min}$ & $30 \mathrm{~min}$ \\
\hline 2600 & $\overline{t Z, M}$ & $\overline{\square Z, M}$ & $\overline{Z, M}$ & $\overline{\mathrm{Z}, \mathrm{M}}$ & $\underset{\mathrm{mZ}}{\mathrm{Z}, \mathrm{M}}$ & $\begin{array}{c}\mathrm{Z}, \mathrm{M} \\
\mathrm{mZ}\end{array}$ & $\begin{array}{l}\mathrm{tZ,M}, \mathrm{M} \\
\mathrm{mZ}, \mathrm{C}\end{array}$ \\
\hline 2400 & $\mathrm{Z}, \mathrm{M}$ & $\overline{Z, M}$ & $\overline{Z, M}$ & $\overline{t Z, M}$ & $\mathrm{ZZ,M}$ & $\mathrm{Z}, \mathrm{M}$ & $\mathrm{ZZ}, \mathrm{M}$ \\
\hline 2200 & $\underline{Z, M}$ & $\underline{Z, M}$ & $\overline{Z, M}$ & $\overline{\mathrm{Z}, \mathrm{M}}$ & $\mathrm{Z}, \mathrm{M}$ & $\mathrm{Z}, \mathrm{M}$ & $\mathrm{Z}, \mathrm{M}$ \\
\hline 2000 & nil & nil & nil & nil & $Z, M$ & $\bar{Z}, \mathrm{M}$ & $\overline{Z, M}$ \\
\hline 1800 & nil & nil & nil & nil & nil & $\bar{Z}$ & $Z$ \\
\hline
\end{tabular}

Table 5.7 Crystalline Phases in the Devitrification of Cerachrome

\begin{tabular}{||c|c|c|c|c|c|c|c|}
\hline \multirow{2}{*}{ TEMP $\left({ }^{\circ} \mathrm{F}\right)$} & \multicolumn{7}{|c|}{ TIME } \\
\cline { 2 - 8 } & $15 \mathrm{~s}$ & $30 \mathrm{~s}$ & $45 \mathrm{~s}$ & $60 \mathrm{~s}$ & $10 \mathrm{~min}$ & $20 \mathrm{~min}$ & $30 \mathrm{~min}$ \\
\hline 2600 & $\mathrm{M}$ & $\mathrm{M}$ & $\mathrm{M}$ & $\mathrm{M}$ & $\mathrm{M}, \mathrm{C}$ & $\mathrm{M}, \mathrm{C}$ & $\mathrm{M}, \mathrm{C}$ \\
\hline 2400 & $\mathrm{M}$ & $\mathrm{M}$ & $\mathrm{M}$ & $\mathrm{M}$ & $\mathrm{M}$ & $\mathrm{M}, \mathrm{C}$ & $\mathrm{M}, \mathrm{C}$ \\
\hline 2200 & $\mathrm{M}$ & $\mathrm{M}$ & $\mathrm{M}$ & $\mathrm{M}$ & $\mathrm{M}$ & $\mathrm{M}$ & $\mathrm{M}$ \\
\hline 2000 & $\mathrm{M}$ & $\mathrm{M}$ & $\mathrm{M}$ & $\mathrm{M}$ & $\mathrm{M}$ & $\mathrm{M}$ & $\mathrm{M}$ \\
\hline 1800 & $\mathrm{M}$ & $\mathrm{M}$ & $\mathrm{M}$ & $\mathrm{M}$ & $\mathrm{M}$ & $\mathrm{M}$ & $\mathrm{M}$ \\
\hline
\end{tabular}

The phases present after heat treatment were determined by powder $x$-ray diffraction. The amount of residual glassy phase present was determined by analysis of the $x$-ray diffraction patterns. The residual glass present after heat-treatment for the three vitreous fibers, as devitrification proceeds, is summarized in Figures 5.5 through 5.7.

\subsection{Significance of the Devitrification Studies}

The results of the $4 \mathrm{~h}$ heat treatment at $2600^{\circ} \mathrm{F}$ show that all three vitreous fibers were devitrified at the end of the heating. The results of the detailed devitrification study show that devitrification begins at $1800^{\circ} \mathrm{F}$ in $<15 \mathrm{~s}$ for Cerachrome, in $<10 \mathrm{~min}$ for Kaowool 2600, and in $<20 \mathrm{~min}$ for Kaowool ZR. For these three vitreous refractory insulating fibers, the microstructural changes that result in the loss of insulating properties occur the first time the fibers are brought to operating temperatures above $1800^{\circ} \mathrm{F}$. 
Figure 5.5 Amorphous Residual During Devitrification of Kaowool 2600 Wt\%

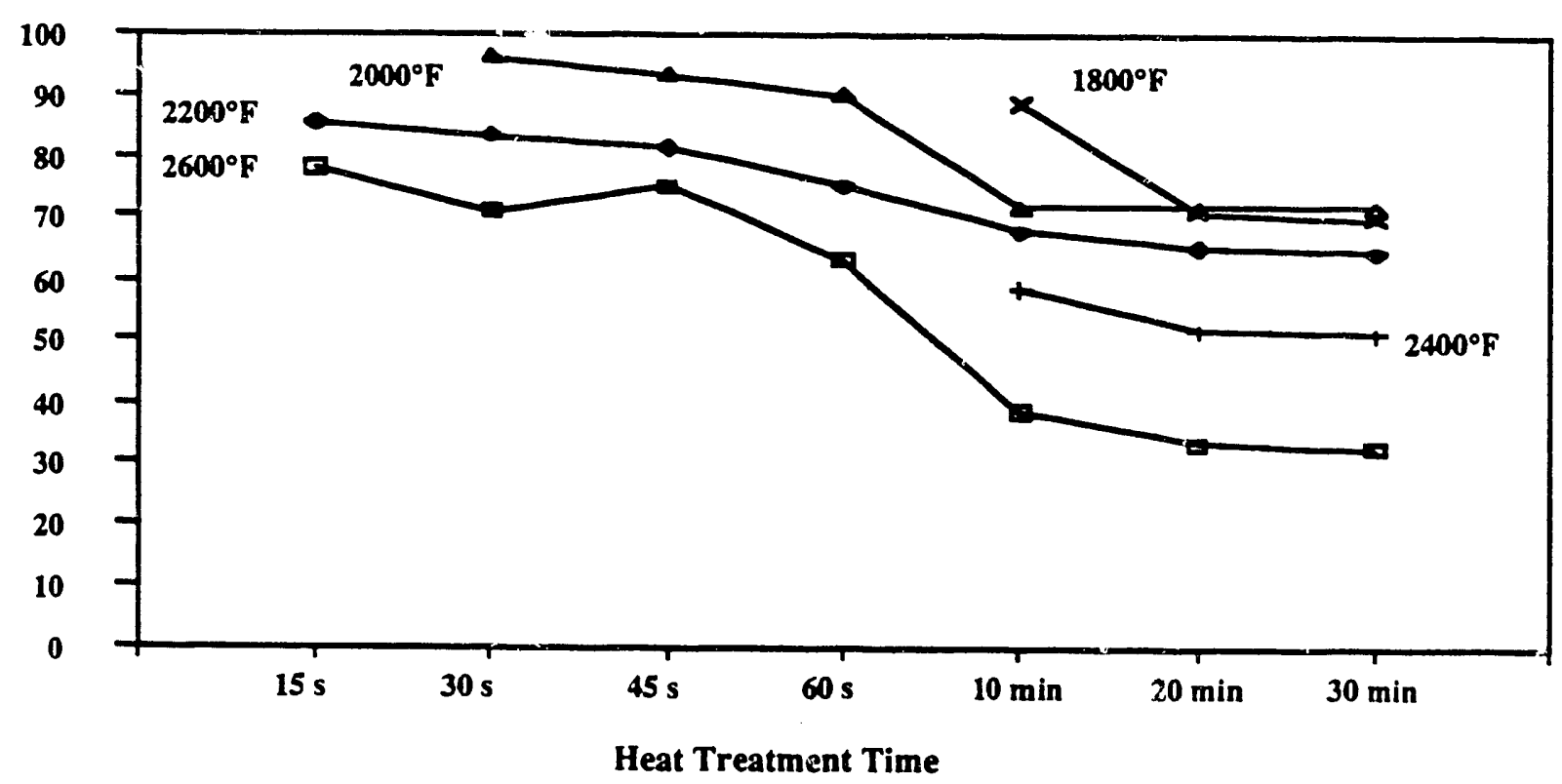

Figure 5.6 Amorphous Residual During Devitrification of Kaowool ZR

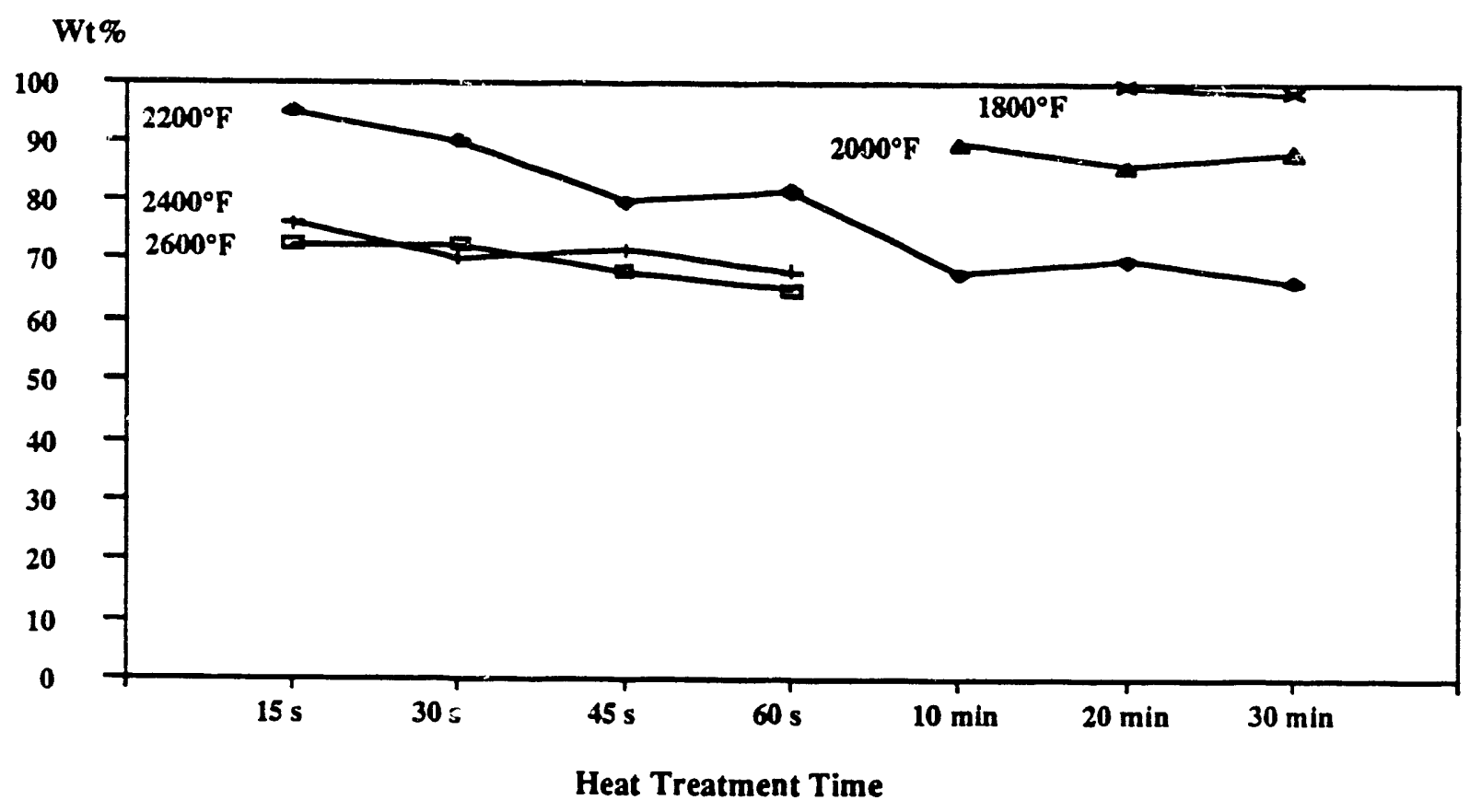


Figure 5.7 Amorphous Residual During Devitrification of Cerachrome Wt\%

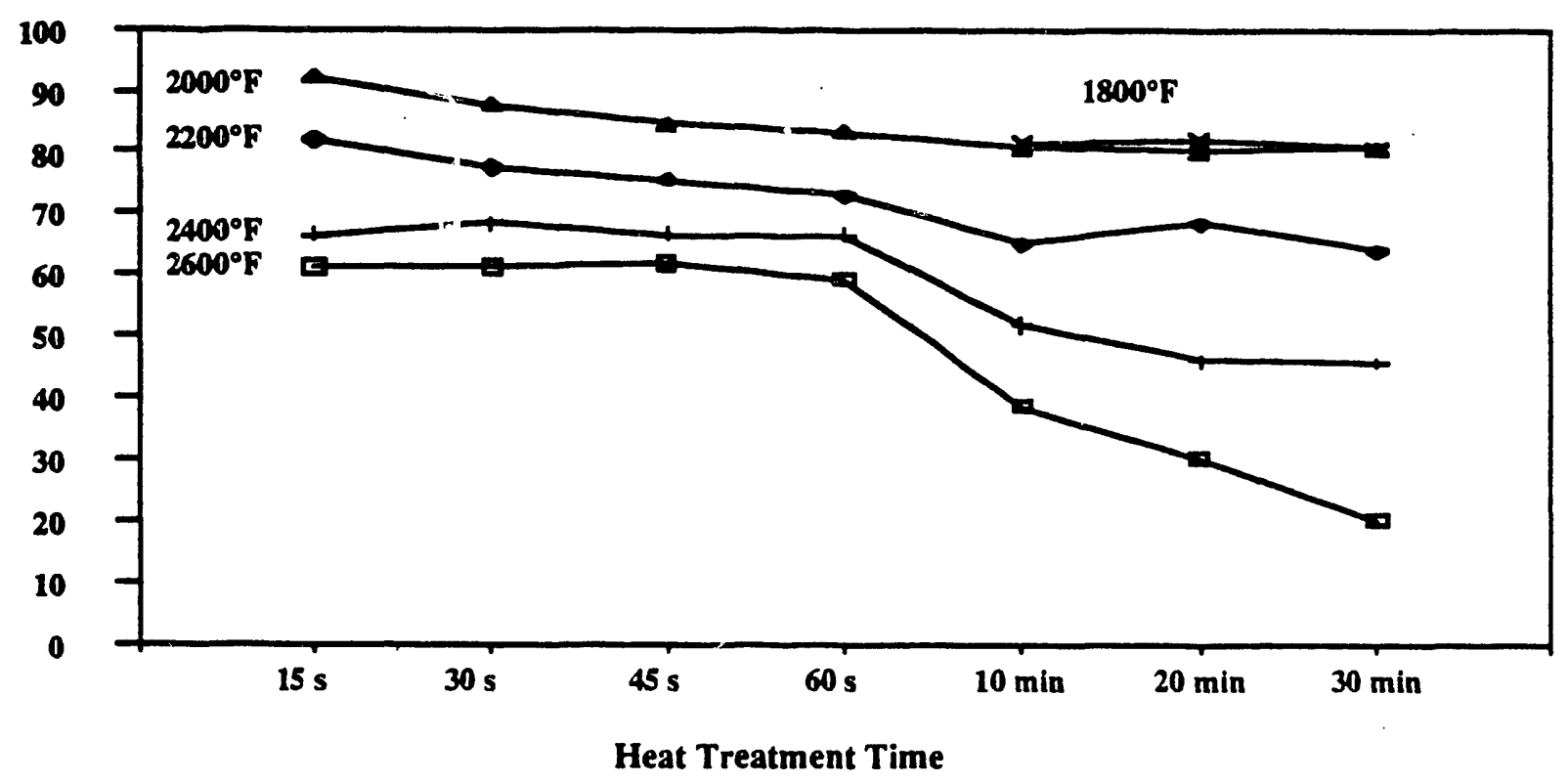




\section{ENERGY SAVINGS ANALYSIS}

\subsection{Selection of Furnaces for Modeling}

There are two types of high temperature $\left(500\right.$ to $\left.1700^{\circ} \mathrm{C}\right)$ heating processes in the manufacturing industries. These are the batch and continuous duty heating processes. Batch furnaces have two basic geometries, cylindrical and rectangular box. Whereas the continuous duty furnaces occur in the rotary hearth, or toroidal, and the rectangular tunnel geometries.

Because the capabilities of both computer programs used in this study were limited to modeling two-dimensional geometries, the only batch furnace numerically modeled was the cylindrical or axisymmetric furnace, with the axis of symmetry parallel to the gravitational vector. Bell or pit furnaces are frequently designed with a cylindrical geometry in this orientation (Koch, 1987). A schematic of this type of furnace is shown in Figure 6.1.

In addition to the cylindrical furnace, three continuous duty furnaces such as the walking beam, rotary hearth, and tunnel kiln were modeled and schematics are provided for these furnaces in Figures 6.2, 6.3, and 6.4. The physical dimensions of the rotary hearth and tunnel kiln were those of furnaces currently operating at local brick and steel manufacturers, respectively. Tours of both facilities were beneficial in the pursuit of acquiring dimensional and working energy consumption data on these furnaces (Arner, 1989, Stumpff, 1989 and Moore and Walker, 1989). The dimensions of the walking beam were obtained from the literature (Braun, 1982).

\subsection{Cylindrical and Box Batch Furnaces}

The cylindrical batch furnace modeled in this study was similar to a coil steel annealing furnace (Jaluria, 1984). The interior boundary conditions for the modeled furnaces differed slightly from each other. The cylindrical batch furnace and the continuous duty walking beam furnaces were the first to be modeled and rather complicated procedures were utilized to approximate the radiative heat transfer from the flame and hot gases to the inner wall (Blokh, 1988 and Cai, 1990). In addition, the convective heat transfer coefficient for the inner cylindrical furnace wall was determined from standard external flow heat transfer correlations (Incropera and DeWitt, 1990). The gas velocity was assumed to be $10 \mathrm{~m} / \mathrm{s}$ (Jaluria, 1984). As shown in Figure 61 , the walls were modeled as composite layers of refractory fiber insulation with successively lower bulk densities from the inside and moving outward. The properties of Cerachrome were used in this model. 
Because three-dimensional computer programs were not available for this study, an alternate analysis was performed comparing the results of the axisymmetric batch furnace and a rectangular box furnace. Conduction shape factors (Incropera and DeWitt, 1990) were used to approximate the steady state heat loss through a box furnace. The basic assumption made in utilizing this technique is that the inside and outside furnace wall temperatures are known and uniform. The horizontal box interior dimensions were assumed to be square and the area was assumed to be equal to the area of the axisymmetric case modeled by computer. This is believed to be a reasonable assumption because both furnaces could be used to heat the same size product. A comparison of these batch furmace geometries is provided in Subsection 6.7.

Figure 6.1 Cylindrical Furnace Model

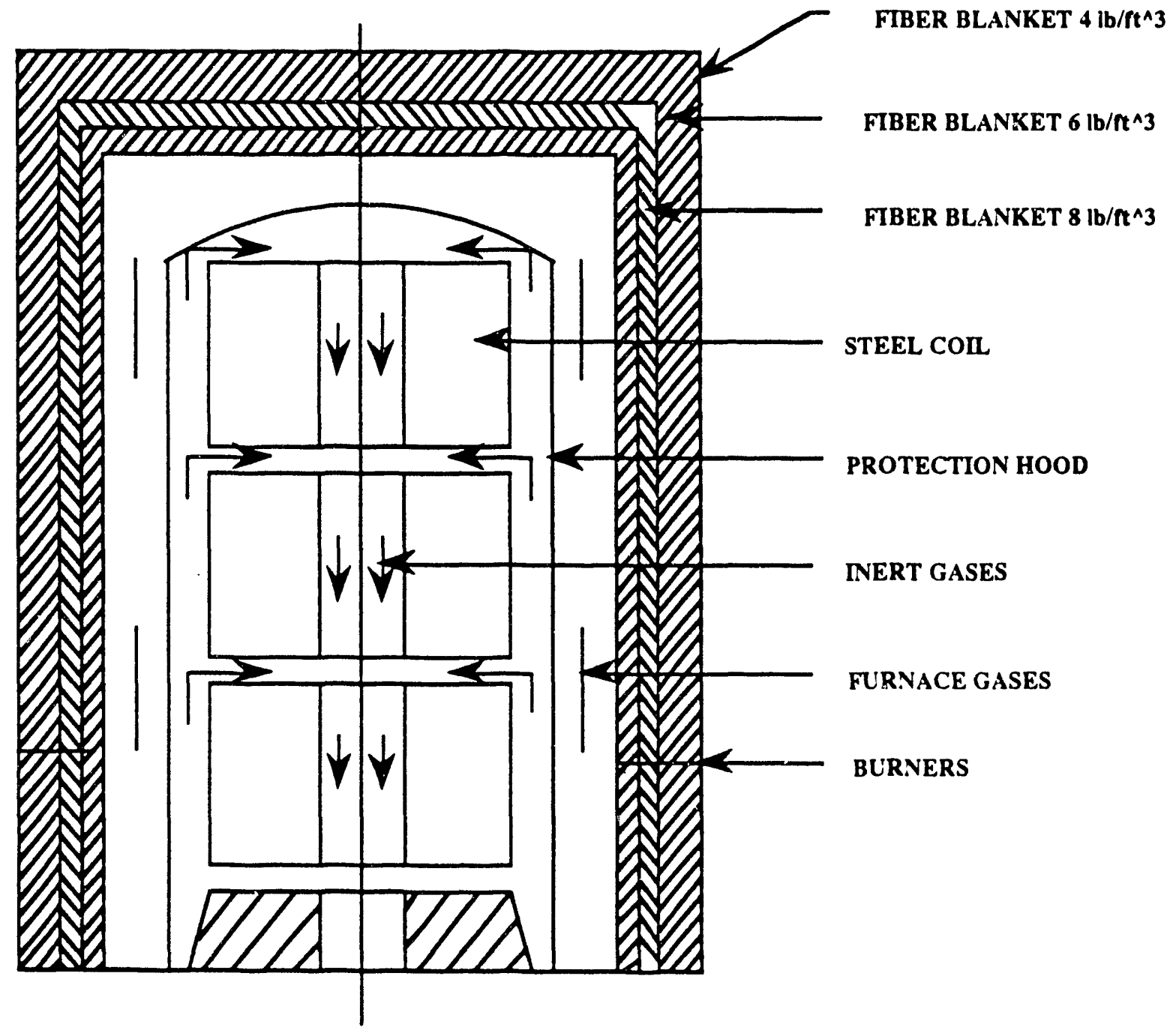


Figure 6.2 Typical Walking Beam Furnace
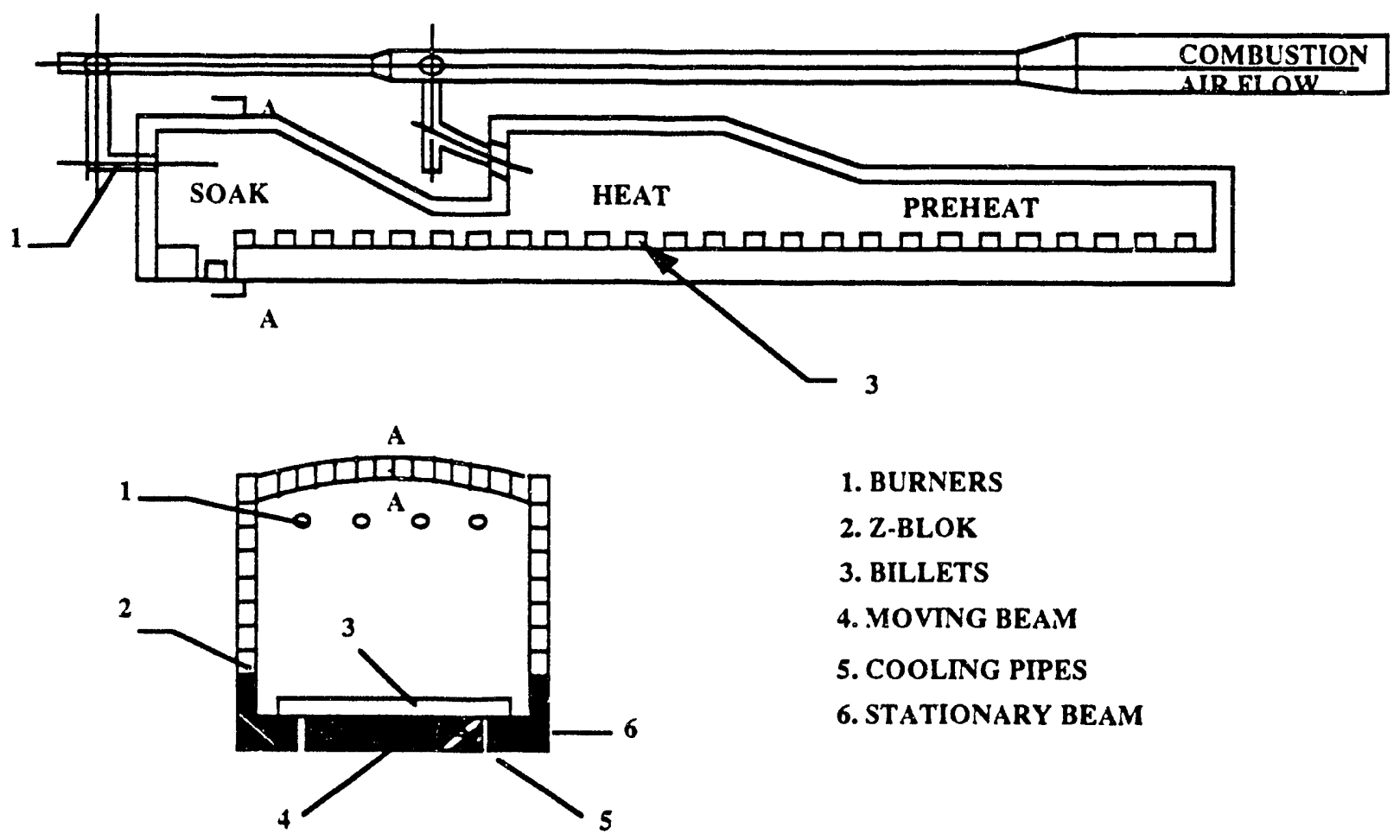

1. BURNERS

2. Z-BLOK

3. BILLETS

4. MOVTNG BEAM

5. COOLING PIPES

6. STATIONARY BEAM 
Figure 6.3 Typical Rotary Hearth Furnace
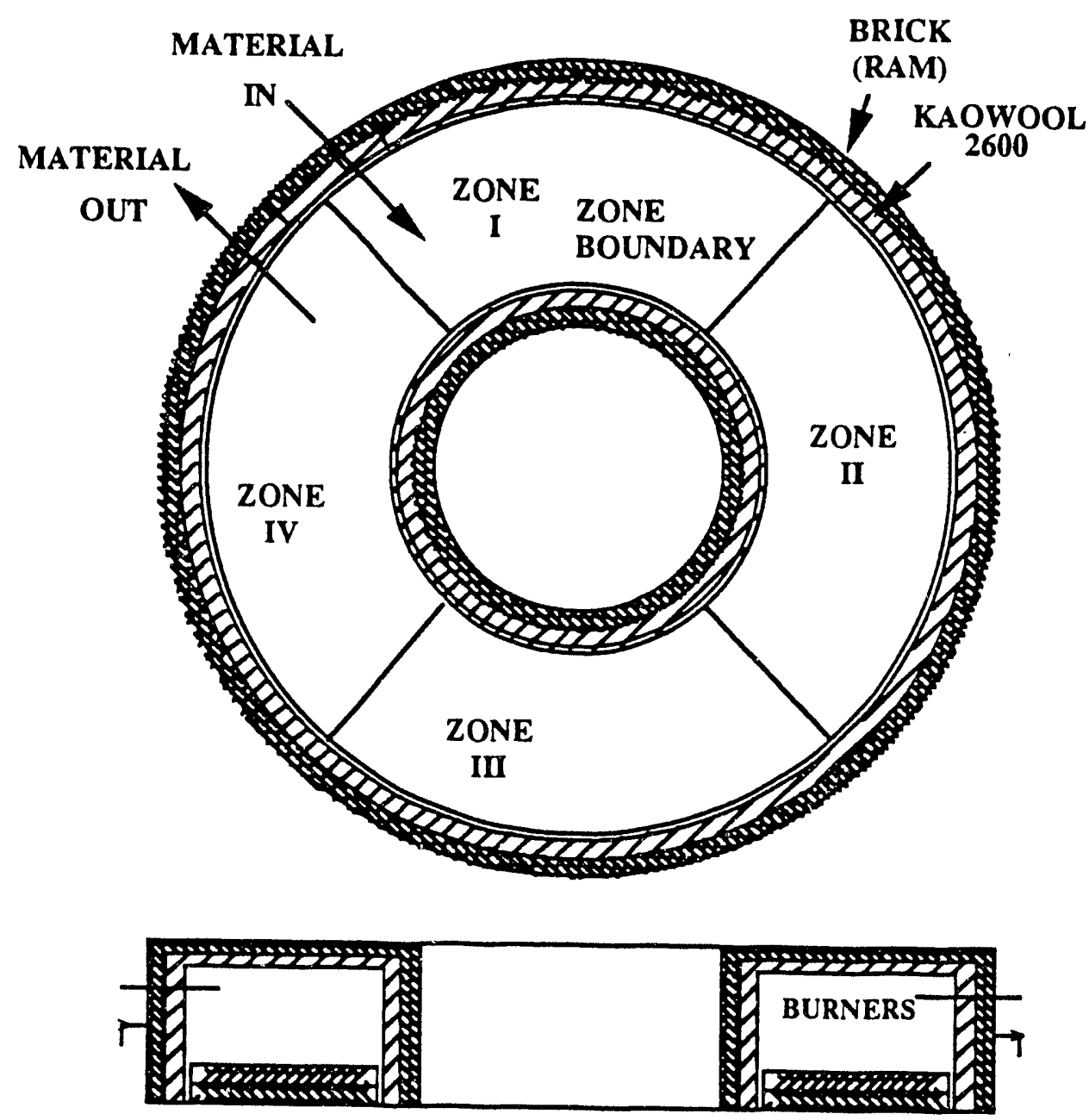


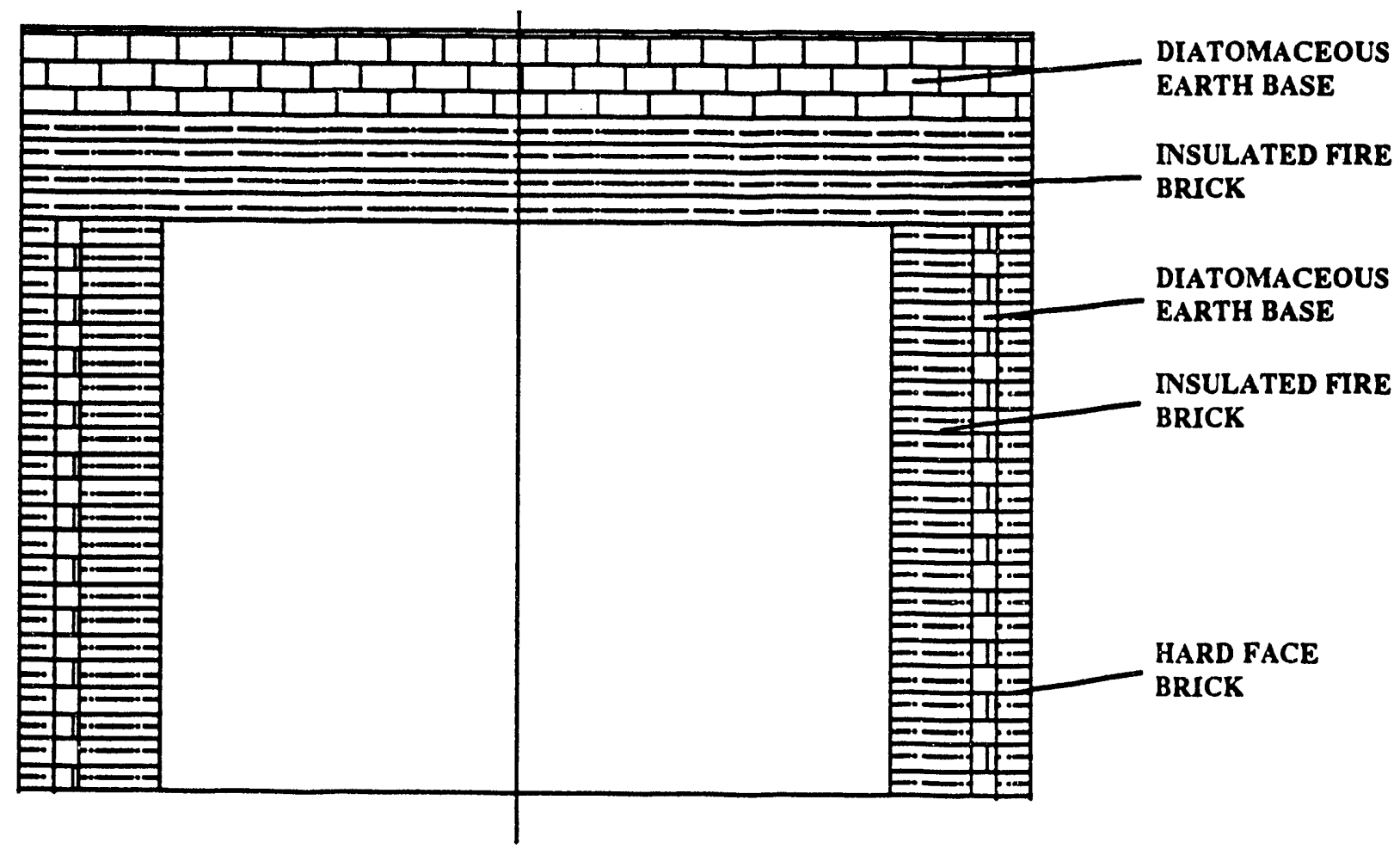

\subsection{Walking Beam, Rotary Hearth, and Tunnel Kiln Continuous Duty Furnaces}

The continuous duty furnaces were divided into different zones for modeling purposes. This approach is similar to the methods used to control furnace operation. In the industrial fumaces that were observed in operation (Moore and Walker, 1989, Stumpff, 1989 and Amer, 1989), each zone had a bank of burners that were controlled by temperature set points for that particular zone. Fuel was added to the burners in each zone until the set point temperature was reached. As heat losses occur in the zone, the zone temperature drops, resulting in a control signal for the burners to cycle $\mathrm{ON}$, until a tolerance on the temperature set point was exceeded, then back off again, thereby maintaining a nearly constant zone temperature.

The walking beam furnace was modeled using the thermal properties of fibers whose working temperatures coincide with appropriate industrial zonal temperatures. Table 6.1 provides the operating and fiber working temperature used in each zone of a typical walking beam furnace. 
Table 6.1 Operating Conditions for the Walking Beam Furnace in Three Zones

\begin{tabular}{|l|c|c|c|}
\hline \multirow{2}{*}{ ZONE } & \multicolumn{2}{|c|}{ OPERATING TEMPERATURE } & \multirow{2}{*}{ FIBER TYPE } \\
\cline { 2 - 4 } & $9 \mathrm{~F}$ & \multicolumn{1}{c}{$\mathrm{C}$} & SAFFIL \\
\hline Soak & 2350 & 1288 & FIBERMAX \\
\hline Heat & 1850 & 1010 & KAOWOOL 2600 \\
\hline Preheat & 1400 & 760 & \\
\hline
\end{tabular}

The inner wall boundary conditions for the walking beam furnace were flame and gas radiation and forced convection. The flame and gas temperatures were taken to be the temperature set point for that particular zone. Each zone was also assumed to have a large blower providing well mixed preheated air over the product. Assumed blower capacities were similar to those used in industry (Moore and Walker 1989). A zero-order model was used to approximate the convective velocity from the blower volumetric flow rates. The convective coefficients were then determined from standard forced convective heat transfer correlations.

Inner wall temperatures for the rotary hearth and tunnel kiln were assumed to be constant and uniform over the entire zone. As in the walking beam furnace, actual temperature set points for local industrial furnaces were used (Moore and Walker, 1989 and Stumpff, 1989). The boundary conditions for the cylindrical and walking beam furnaces are described by Cai, (1990). Four zones were modeled in the rotary hearth and three zones were modeled in the tunnel kiln, as shown in Table 6.2. All of the furnaces were modeled using convective and radiative boundary conditions at the outer wall surface.

\section{Table 6.2. Temperature Set Point for Industrial Furnace Zones}

\begin{tabular}{|l|c|c|c|c|}
\hline \multirow{2}{*}{ FURNACE TYPE } & \multicolumn{4}{|c|}{ Temperature Set Points $\left({ }^{\circ} \mathrm{C}\right)$} \\
\cline { 2 - 5 } & Zone 1 & Zone 2 & Zone 3 & Zone 4 \\
\hline Rotary Hearth & 1038 & 1149 & 1204 & 1232 \\
\hline Tunnel Kiln & 982 & 1071 & 1177 & \\
\hline
\end{tabular}

\subsection{Selection of the Computer Programs}

Two computer codes previously developed by the Department of Energy were used to model heat losses through the walls of industrial furnaces. The code names are Determination of Temperature, DOT (INTERA, 1982) and TOPAZ2D (Shapiro, 1986). The DOT code was chosen because it could be run on an International Business Machines (IBM) compatible personal computer, which allows the use of the DOT program in a typical industrial setting. It was desirable to develop the 
capability of taking the program (loaded in a lap top PC) into an industrial environment to quickly analyze a furnace wall and storage heat losses to prove the potential energy savings when an improved refractory fiber is used over existing fiber or refractory brick.

The running time for the DOT program is acceptable on the PC, primarily because the nonlinear boundary conditions associated with the radiation component of heat transfer are linearized with a simplified noniterative technique. However, this simplification, although resulting in higher program efficiencies, can result in substantial inaccuracies in the heat loss calculation. Therefore, the TOPAZ2D code was chosen as a secondary model because of its added sophistication to verify the accuracy of the DOT code results. However, it must be run on a much faster main frame or mini computer. The DOT code provided the most reliable results when the radiation boundary condition was avoided at the inside or hot furnace surfaces. Computer runs of the DOT code that included convective and radiative boundary conditions at the outer surface yielded acceptable agreement with identical conditions run in the TOPAZ2D code. The only exception to this is in the outer boundary element immediately adjacent to the axis of symmetry of the cylindrical furnace model. However, this aberration did not significantly affect the energy calculation results. Although there are these concerns about inaccuracies of the DOT code, heeding the warnings described above, the results from both computer codes compare well with several analytical solutions (Cai, 1990) and with each other when the inside surface boundary condition is a known and uniform temperature. Figures 6.5 and 6.6 provide a comparison of runs with identical conditions performed on both the DOT and TOPAZ2D codes.

Both programs utilize the finite element technique and can be used to solve two-dimensional, axisymmetric, or cartesian transient heat conduction problems with radiation and convection or known temperature boundary conditions. Also, both programs are capable of modeling thermal systems that involve thermophysical property variations with temperature. The rather weak nonlinearities associated with temperature dependent properties do not compromise the accuracy of either program. However, the strong nonlinearities introduced by the radiation boundary conditions can have a significant effect on the results of the DOT code (particularly when the temperatures are high, as for common furnace operating temperatures) and near lines of symmetry such as near the centerline of the axisymmetric geometries. In general, both programs have been used extensively in this study and in other science and engineering projects (INTERA, 1982 and Shapiro, 1986). Therefore, the level of confidence in the codes (with knowledge of the above mentioned limitations) remains high. 
Figure 6.5 Comparison of DOT and TOPAZ Codes, Cold-Side

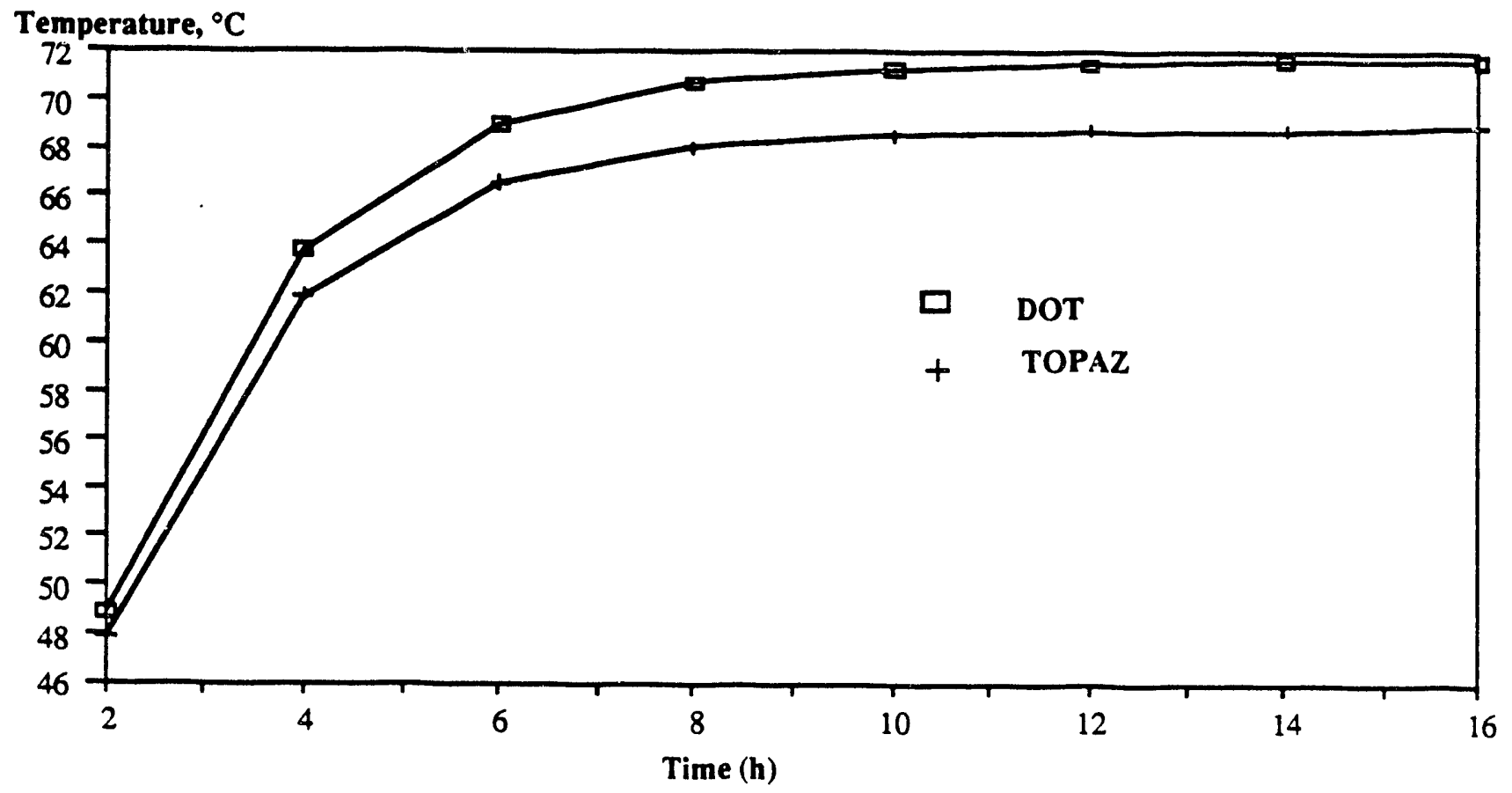

Figure 6.6 Comparison of DOT and TOPAZ Codes, Wall Mid-Plane

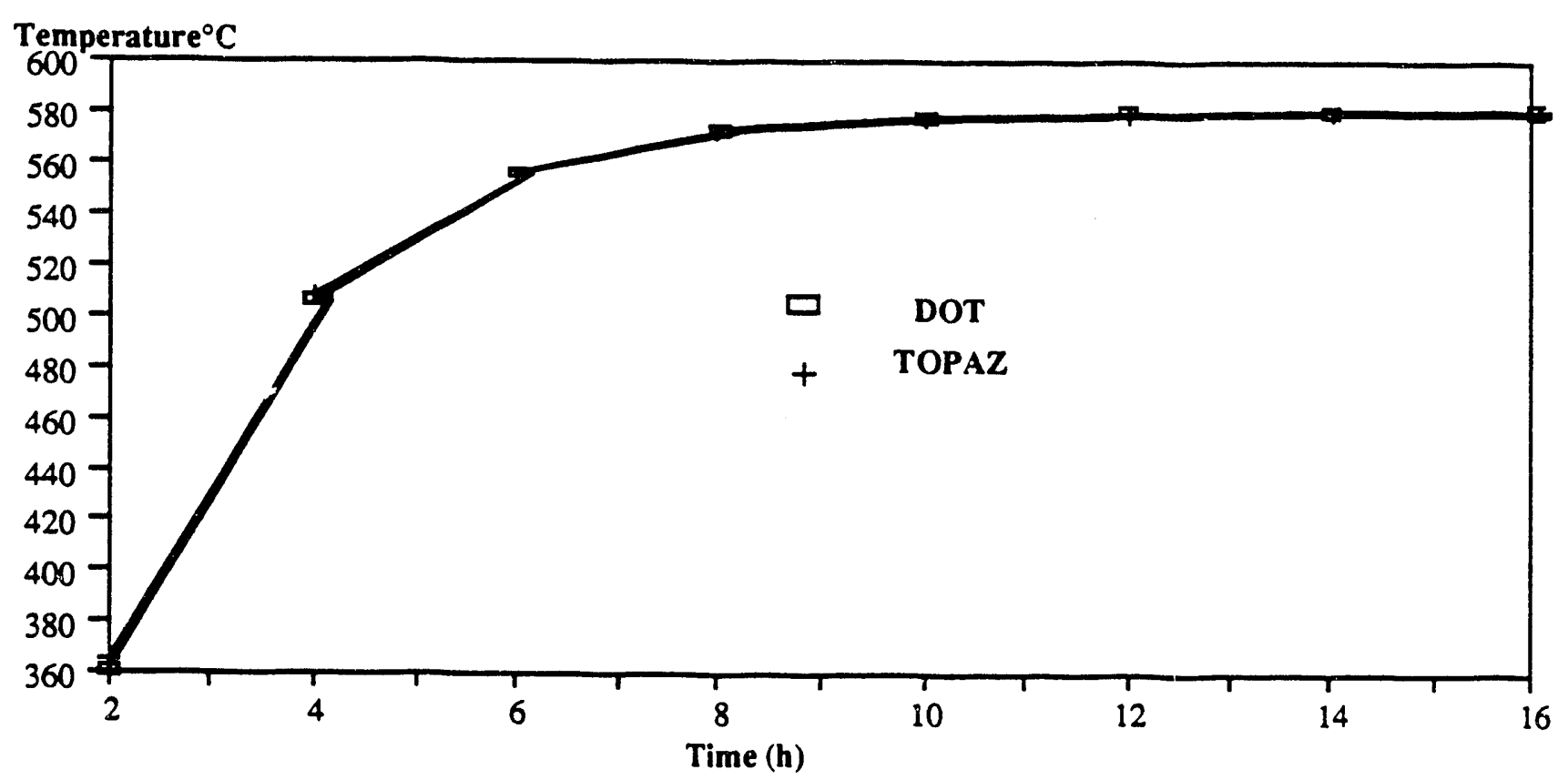




\subsection{Modification of the Computer Codes}

The DOT and TOPAZ2D codes were written to calculate the temperature distribution of the thermal system of interest. However, the DOT code did not have the capabilities of calculating the steady state wall heat losses or the transient wall energy storage. Modifications of the code were made to account for these heat losses and storage factors.

Steady state wall losses were determined by summing the radiation and convection heat losses for each boundary element at the ourer wall surface. These outer wall losses were determined with knowledge of the steady state outer surface temperature and the convective and radiative heat transfer coefficients. Convective coefficients were determined with standard empirical free convection heat transfer correlations. The radiative heat transfer coefficient is a function of the outer wall surface emissivity and the temperatures of the outer wall surface and surroundings (Incropera and DeWitt, 1990). With the exception of the inner outside wall of the toroidal rotary hearth furnace, the geometrical configuration factor from the outer furnace wall to the surroundings was taken to be 1 . Differential configuration factors were used for the radiation boundary conditions on the inner outside wall of the rotary hearth because that wall could see itself, thereby resulting in a reduction in radiative losses caused by the relatively high inner toroid outer wall temperatures.

The energy storage calculation was performed for each element in the domain. The difference between the element final and initial temperatures was multiplied by the bulk density and the temperature dependent specific heat of the refractory fiber wall. After steady state was reached, the energy storage for each element was summed to yield the total energy required to heat the furnace wall from standard ambient temperature to the furnace operating temperature.

\subsection{Fiber Properties Used in the Modeling}

As indicated in Section 5., the thermal conductivity and shrinkage of the refractory fibers chosen for this study were measured both in the as-received state and after heat treatment. The as-received fiber thermal physical properties are designated as "enhanced" and the properties of the fibers after heat treatment are designated as existing. The properties of an enhanced fiber therefore represent the desired thermal physical properties of an improved fiber that remains amorphous after heat treatment. The energy losses for each furnace using both enhanced and existing fibers are compared in the next section. The difference in the calculated energy losses represents the potential energy savings when an improved fiber is used over an existing, commercially available fiber. 


\subsection{Modeling Results}

The results from the modeling activities are tabulated in Table 2.2. Table 2.2 provides a comparison of the calculated steady state heat losses for the furnaces chosen for analysis in this study. Each furnace was modeled with various fibers in place. The cylindrical furnace was modeled using the properties for the three bulk densities of Cerachrome. The Walking beam insulating materials are listed in Table 6.1. Thermal properties of Kaowool 2600 were used to model the inner lining of the rotary hearth furnace and tunnel kiln. The comparison shows that there is the potential for substantial energy savings when an improved fiber is used over those that are currently commercially available. The steady-state results indicate that, for the furnaces modeled, 11 to $19 \%$ of the heat transferred through the wall can be saved when using an enhanced fiber over an existing fiber. These percentages will be used in Section 7 to determine the annual potential energy savings for the primary metal reheat, ferrous metal heat treating, and ceramic heating processes in the United States.

Because it was impossible to model a rectangular (box) batch furnace numerically in this study, a simplified comparison between a box and cylindrical furnace was employed. The steady state wall heat losses for the cylindrical furnace were determined with known and uniform temperature boundary conditions inside and out of $\mathrm{T}_{\text {in }}=1000^{\circ} \mathrm{C}$ and $\mathrm{T}_{\text {out }}=100^{\circ} \mathrm{C}$. The physical dimensions were the same as shown in Figure 6.1. For this configuration, the steady state wall heat losses were $14.8 \mathrm{~kW}$. A technique involving conduction shape factors (Incropera and DeWitt, 1990) was used to determine the steady state losses from a rectangular furnace with the same horizontal crosssectional area, height, and insulation thickness. The wall loss for this box furnace was $14.1 \mathrm{~kW}$. With the rough approximations made, it is reasonable to assume that the percent of wall heat losses from the cylindrical furnaces are similar to those of rectangular furnaces with the same internal volume.

The storage losses determined from the transient analysis of the cylindrical furnace, insulated with enhanced and existing fibers, are compared in Table 6.3. Note that the difference in the storage losses when the enhanced and existing fibers are used is small, averaging $4 \%$. Nonetheless, it was interesting to find that there was a difference in heat storage between the furnaces using the enhanced and existing fiber. Because the mass of the enhanced and existing fibers was the same, the small difference in heat storage is caused by the differences in the calculated temperature distributions and the corresponding effect on the temperature dependent specific heat for the two cases. According to Koch, (1987) nearly $80 \%$ of the furnaces used in the ferrous metal heat treating industries, $\sim 1 / 3$ of the energy consumption sector under consideration in this study, are batch furnaces. Therefore, a $4 \%$ reduction in each cycle of the batch furnaces in these industries 
could yield a significant energy savings. The uncertainties that remain regarding the number of batch furnace cycles per year and lower temperature limit between cycles will require further study.

Table 6.3 Energy Losses Through in: Enhanced and Existing Fiber Wall in the Cylindrical Furnace

\begin{tabular}{||l|c|c|c|c||}
\hline \multicolumn{1}{|c|}{ MATERIAL } & CODE & $\begin{array}{c}\text { Wall Heat Losses } \\
\left(10^{3} \mathrm{Btu} / \mathrm{h}\right)\end{array}$ & $\begin{array}{c}\text { Heat Storage } \\
\left(10^{3} \mathrm{Btu} / \mathrm{h}\right)\end{array}$ & $\begin{array}{c}\text { Total energy } \\
\left(10^{3} \mathrm{Btu} / \mathrm{h}\right)\end{array}$ \\
\hline Enhanced Fiber & DOT & 137.75 & 66.21 & 204.00 \\
\hline Existing Fiber & DOT & 153.82 & 72.38 & 226.24 \\
\hline Energy Saving Rate (\%) & 10.4 & 8.5 & \\
\hline & TOPAZ & 130.53 & 55.83 & 186.42 \\
\hline Enhanced Fiber & TOPAZ & 145.43 & 56.14 & 201.55 \\
\hline Existing Fiber & 10.3 & 0.5 & \\
\hline Energy Saving Rate (\%) & &
\end{tabular}

\subsection{Energy Savings Calculation}

Recall that these are the energy consumption estimates (McDermott and Chapman, 1988) for specific processes in the primary metals reheat, ferrous metal heat treating, and ceramic heating industries (See Table 2.1). These were the process areas that the authors felt were the most appropriate for refractory fiber usage. The energy consumption is divided into two categories, electrically heated furnaces and gas or other fossil fuel. The electrical energy consumption column of Table 2.1 was summed and divided by 0.34 , which represents the efficiency of converting another conventional fuel into electricity. This figure was added to the sum of the furnaces burning fossil fuels, resulting in 0.7035 quad of energy consumed in the industries chosen for this detailed analysis.

A literature survey was performed in an attempt to estimate the fraction of energy losses associated with the furnace wall. Wall heat losses can account for 5 to $38 \%$ of the total energy input. Table 6.4 lists a number of batch and continuous furnaces previously analyzed (Budacki, 1983, Casana and Stabile, 1983, Hollander and IJmuiden, 1983, Molloy, 1985, Viskanta and Menguc, 1987, and Vance, 1985). An average wall heat loss of 10 to $20 \%$ was assumed to be a conservative estimate for the furnaces considered in this study. 
Table 6.4 Reported Wall Heat Losses for Typical Industrial Furnaces

\begin{tabular}{||l|c|l||}
\hline \multicolumn{1}{|c|}{ FURNACE } & $\begin{array}{c}\text { WALL LOSSES } \\
(\%)\end{array}$ & $\begin{array}{c}\text { REFERENCES } \\
\text { (author) }\end{array}$ \\
\hline Soaking Pit & 10 & Hollander \\
\hline Pusher Slab Reheating & 13 to 20 & Vance \\
\hline Radiant Tube Heat Treat & 22 to 38 & Industrial Heating \\
\hline Flashheat & 9 & Molloy \\
\hline Roller Hearth Reheating & 5 to 10 & Budacki \\
\hline Continuous Walking Beam Hardening & 9 to 11 & Casana \\
\hline Continuous Walking Beam Tempering & 16 & Casana \\
\hline Preheat & 14 & Molloy \\
\hline Typical Industrial & 14 & Viskanta \\
\hline
\end{tabular}

The modeling results, Subsection 6.7 , indicate that 11 to $19 \%$ of the wall losses could be saved when using an enhanced over an existing refractory fiber. Combining the percent wall losses (Table 6.4) of the total furnace input energy and the percent savings when an enhanced fiber is used over existing fiber, yields 1.1 to $3.8 \%$ energy savings when an enhanced refractory fiber is used over a commercially available fiber. The resultant potential annual savings ranges from 0.0077 to 0.0267 quad.

Although only the Metals and Ceramics industries were specifically targeted for application of an improved refractory fiber, the Chemicals and Allied Products and Petroleum and Coal Products industries consume many times more energy. According to a report by the Energy Information Administration (1988), Chemicals and Allied Products consumed 3.567 quad annually and Petroleum and Coal Products consumed 5.123 quad annually. Possible applications, at temperatures exceeding $1500^{\circ} \mathrm{C}$, of enhanced refractory fiber in the Chemical and Allied Products industries include:

1. Heater and reformer linings

2. Pigtail insulation

3. Reformer header insulation

4. Lining of hot gas ducts

5. Weld insulation.

In the Petroleum and Coal Products industries, Fineproofing at $1300^{\circ} \mathrm{C}$ (one process) was identified as having potential for use of refractory fiber. However, a less than exhaustive search was performed in these industries, primarily because it was felt unnecessary to meet the required criteria of 0.01 quad annual energy savings. In addition, there are numerous processes, in the glass and aluminum industries, that are also potentially appropriate for use of refractory fiber 
materials. Therefore, a much more detailed analysis will be required in these industries to identify the specific processes where refractory fiber usage is feasible.

A rough estimate of the energy savings potential in the chemical and petroleum industries can be made if it is assuri ed that $50 \%$ of the energy consumed in these industries is associated with high temperature, nonreducing processes. As before, if $10 \%$ of the energy input to these processes is lost through the furnace walls and $10 \%$ of this energy can be saved through the use of an improved refractory fiber, then an additional 0.044 quad of energy could be saved annually in the chemical and petroleum industries.

During visits to local refractory and steel manufacturers, it was found that workers would use fiber to fill between cracks that develop between refractory brick and around furnace door jambs.

Modeling the heat loss savings for this application was not performed. However, improved fiber properties could also result in substantial energy savings for this type of application. 


\section{TECHNOLOGY SUMMARY}

The objectives of this first research phase have been to assess the current technology and use patterns of existing refractory fibers, to establish a data base on currently used refractory fibers, and to develop an estimate of the potentially attainable energy savings as a result of developing enhanced insulating property and service lifetime fibers.

The current use patterns of refractory fibers span a wide range of industries and high temperature furnaces within those industries. The majority of high temperature fiber applications are in furnaces operating between 2000 and $2600^{\circ} \mathrm{F}$. The fibers used in furnaces opera $\mathrm{ig}$ within this range provide attractive thermal resistance and low thermal storage at reasonable cost. Higher temperature applications require significantly more expensive materials. The applications and analyses of the observed savings through the use of existing refractory fibers has been documented in the literature as included in the technology data base included in this report.

A series of heat treatment studies performed for this phase of the program has shown that the refractory fibers as initially manufactured have attractive thermal conductivities for high temperature applications but the fibers go through rapid devitrification and subsequent crystal growth upon high temperature exposure. Exposure of the as-manufactured fibers to furnace temperatures well below the service temperatures of the fibers causes significant thermal conductivity and microstructural changes. This results in higher heat losses through the furnace walls and shortened service lifetime because of increased brittleness of the fibers.

Development of improved fibers (maintaining the favorable characteristics of the existing asmanufactured fibers) could save between 1 and $4 \%$ of the energy consumed in high temperature furnaces using refractory fibers. This savings is on the order of 0.01 to 0.03 quad Btu/y. These savings have been calculated based on models comparing furnaces insulated with existing fibers that degrade and furnaces insulated with the to be developed fiber(s) of this program.

The devitrification studies performed for this phase indicate that the rate of crystalline phase development is quite rapid but possibly can be limited or suppressed sufficiently so that the fibers can retain the favorable characteristics of the vitreous as-manufactured fibers. Combining the proper refractory oxide phase compositions with properly controlled fiberization processes could result in new improved high temperature fibers. 


\section{REFERENCES}

Arner, Wayne, Personal Communication, Coors Ceramics Company, Golden, CO, August 1989.

Blokh, A.G., Heat Transfer in Steam Boiler Furnaces, Hemisphere Publishing Corp., 1988.

Budacki, J.E., "Roller Hearth Furnace with High Velocity Jet Burners Saves Fuel in Reheating Plate Uniformly", Industrial Heating, no. 12, December 1983, pp. 30-32.

Cai, Yifang, "Numerical Modeling of Heat Transfer in a Furnace Wall at High Temperature with Convection and Radiation Boundary Conditions", M.S. Thesis in Applied Mechanics, T-3979, Colorado School of Mines, December 1990.

Casana, A. and Stabile, V., "Continuous Walking Beam Furnace Facility -- Design Aspects and Operating Data for Heat Treating Cylinders," Industrial Heating, no. 10, October 1983, pp. 42-43.

Christiansen, Russell, Personal Communication, Geneva Steel, Salt Lake City, UT, 1989.

Courrier, B., Gleitzer, G., Poirson, G., and Sevillaud, L., "Etude de la Recristallisation de Fibres Refractaires", Rev. Int. hautes Temper. Refract. Fr., 19, pp. 9-17, 1982.

Energy Information Administration (EIA), "Manufacturing Energy Consumption Survey: Consumption of Energy, 1985", Department of Energy Report, DOE/EIA-0512(85), November 1988.

Ganz, R. and Kronert, W., "Crystallisation Behavior of High Temperature Ceramic Fibers of the $\mathrm{Al}_{2} \mathrm{O}_{3}-\mathrm{SiO}_{2}$ System", Interceram, NR.2, 1982 pp. 136-144.

Gaodu, A.N., Pitak, N.V., Vol'fson, R.E., and Drizheruk, M.E., "Crystallization in Heated Aluminosilicate Fibers", Izv. Akad Nuak SSSR, Neorg. Mat., 13, (12), 1977 pp. 2265-2268.

Hollander, F., IJmuiden, H., "Reheating Processes and Modifications to Rolling Mill Operations for Energy Savings", Iron and Steel Engineer, June 1983, pp. 55-62.

Incropera, F.P. and DeWitt, D.P., Fundamentals of Heat and Mass Transfer, Wiley, 3rd Edition, 1990.

INTERA, "DOT - A Nonlinear Heat Transfer Code for Analysis of Two-dimensional Planar and Axisymmetric Representations of Structures", INTERA Environmental Consultants Inc., Report OMWL/E512-02900/CD-16, 1982.

Jacobs, Stan, Personal Communication, ALCOA Aluminum, Pittsburg, PA, 1990.

Kerfer, J.R., "Ceramic Fiber Insulation Furnace Research Program", GRI - 86/0202, 1986.

Koch, G.S., McDermott, H. and Klareich, F.H., "Competitive Position of Natural Gas: Ferrous Metal Heat Treating and Atmosphere Generation Applications", Report to the Gas Research Institute, GRI-87/0001, by Hagler, Bailly \& Co., October 1987.

Lippert, Jim, Personal Communication, Kaiser Aluminum, Pleasanton, CA, 1990.

Lo, P., "Devitrification and Recrystallization Processes in Ceramic Refractory Fibers" M.S. Thesis, CSM Thesis Number T-4004, Colorado School of Mines, Golden, CO (1991). 
McDermott, H. and Chapman, M.A., "U.S. Industrial Process Heating Energy Consumption 1985", Report to the Gas Research Institute, GRI-88/0051, by Hagler, Bailly \& Co., February 1988.

Molloy, T.J., "Developments in the Use of Ceramic Fiber to Achieve Energy Reduction in Steel Re-heating Furnace", SEAISI Quarterly, no. 7, July 1985, pp. 14-26.

Moore, Winston and Walker, Walter, Personal Communication, CF\&I Steel Company, Pueblo, CO, 1989.

Riley, Burt and Ellers, Tom, Personal Communication, CF\&I Steel Company, Pueblo, CO, 1990

Schulle, W., Ruppelt, R., and Toppler, B., "Beeinflussung des thermischen Verhaltens feuerfester aluminiumsilikatischer Fasern durch $\mathrm{Cr}_{2} \mathrm{O}_{3}$-Zugabe", Silikattechnik, 37, Heft 11, 1986 pp. 377 379.

Shapiro, A.B., "TOPAZ2D - A Two-dimensional Finite Element Code for Heat Transfer Analysis, Electrostatic and Magnetostatic Prcblems", University of California, Lawrence Livermore National Laboratory, Report UCID-20824.

Sterahan, Dennis, Personal Communication, Reynolds Aluminum, VA, 1990.

Stumpff, Milton, Personal Communication, Robinson Brick Company, Denver, CO, 1989.

Thring, M.W., The Science of Flames and Furnaces, New York: John Wiley and Sons Inc., 1952.

Vance, M.W., "Development of a Non-welded Skid-pipe Insulation for Steel Plant Reheat Furnaces", Industrial Heating, April 1985, pp. 22-26.

Viskanta, R. and Menguc, M.P., "Radiation Heat Transfer in Combustion Systems," Progress in Energy Combustion Science, 13, 1987, pp. 97-160.

Wargo, Thomas, Personal Communication, Salem Furnace Company, Pittsburg, PA, 1990. 


\section{APPENDIX A.1 \\ REFRACTORY INSULATING FIBER DATA BASE}

A. 1.1 


\section{APPENDIX A.1 Refractory Insulating Fiber Data Base}

\section{CATEGORY CODES}

$\begin{array}{ll}\text { ES-C } & \text { Energy Savings: Cases } \\ \text { ES-F } & \text { Energy Savings: Fiber } \\ \text { ES-I } & \text { Energy Savings: Insulation } \\ \text { ES-T } & \text { Energy Savings: Trade } \\ \text { ES } & \text { Energy Savings: Other } \\ \text { F-C } & \text { Furnace: Construction } \\ \text { F-O } & \text { Furnace: Operation } \\ \text { F-S } & \text { Furnace: Simulation } \\ \text { F } & \text { Furnace: Other } \\ \text { RF-P } & \text { Refractory Fiber: Products } \\ \text { RF-E } & \text { Refractory Fiber: Experiment } \\ \text { RF } & \text { Refractory Fiber: Other } \\ \text { AOB } & \text { Any Other Business }\end{array}$

ID

1

AUTHOR Molloy T J

TITLE

Developments in the use of Ceramic Fibre to Achieve Energy Reduction in Steel Re-heating Furnaces

CITATION SEAISI Quarterly v 14 n 3 Jul 1985 p 14-26

CATEGORY ES-C

REMARK This paper is a classic reference for the Manville-CSM Project.

ID 2

AUTHOR Anon.

TITLE

Efficiency of Forge Fumace in Canada Increased with Refractory Fiber and Recuperation

CITATION Industrial Heating v 52 n 4 Apr 1985 p 55

CATEGORY ES-C

REMARK Fiber + Recuperation $=53 \%$ fuel savings $=15 \%$ from fiber and $38 \%$ from recuperator

ID 3

AUTHOR Tye R P

TITLE Improved Energy Recovery: Upgrading Thermal Insulation Performance of Industrial Processes

CITATION Chemical Engineering Progress v 81 n 2 Feb 1985 p 30-34

CATEGORY ES-F

REMARK

ID 4

AUTHOR Kyne W P

TITLE Refractory Fiber as an Insulation in the Forge Industry

CITATION Industrial Heating v 51 n 7 Jul 1984 p 31-33

CATEGORY ES-C

REMARK 


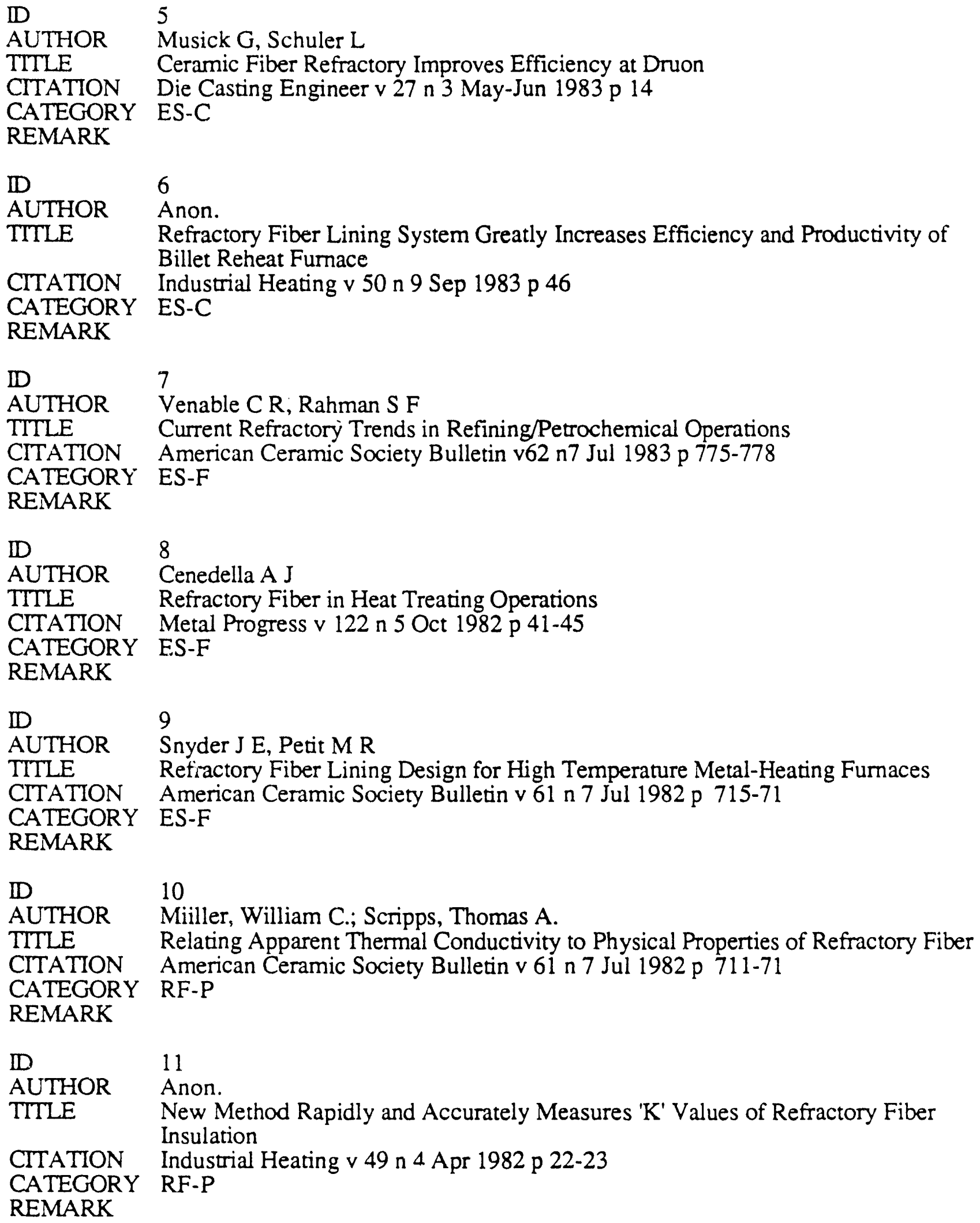




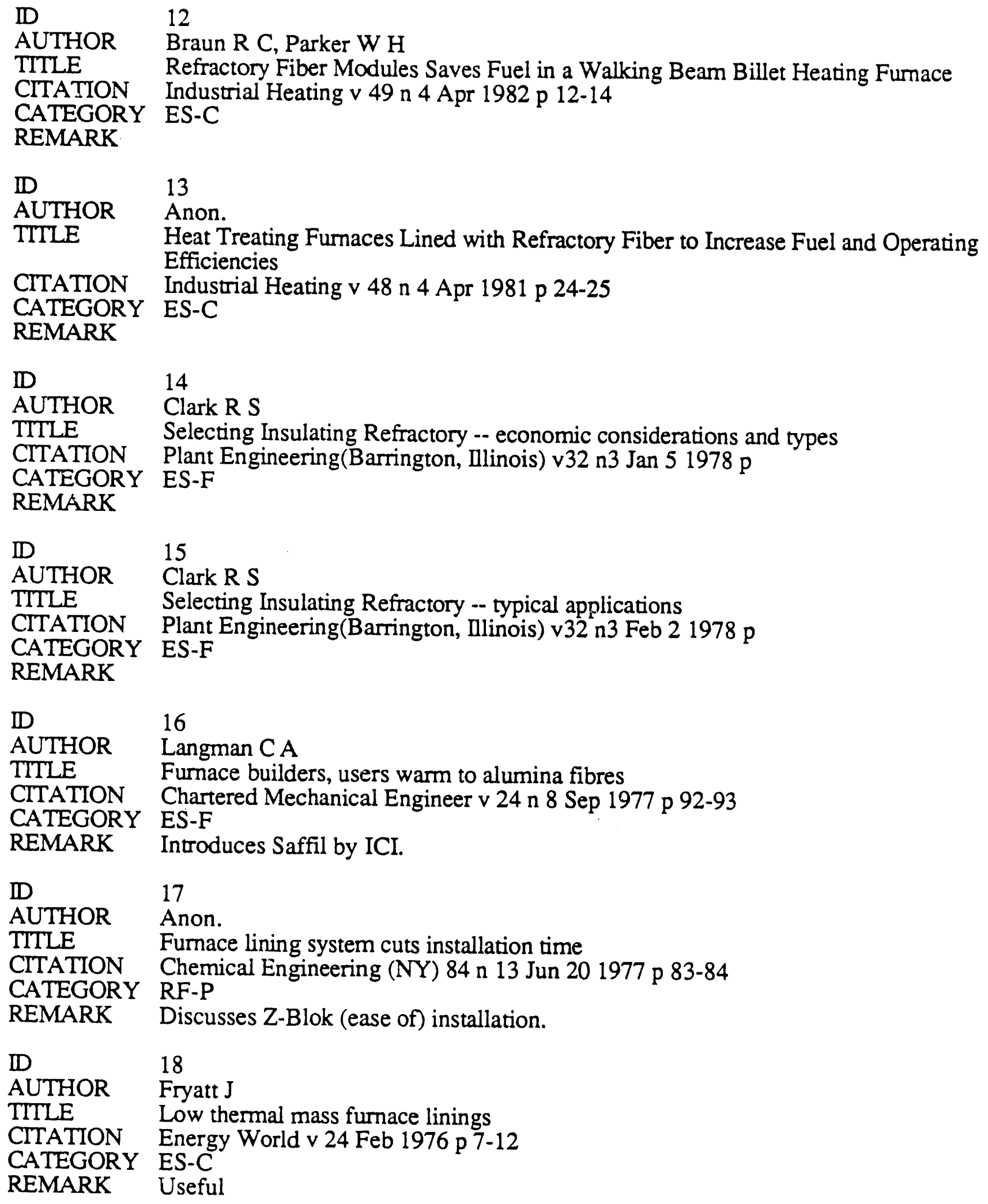




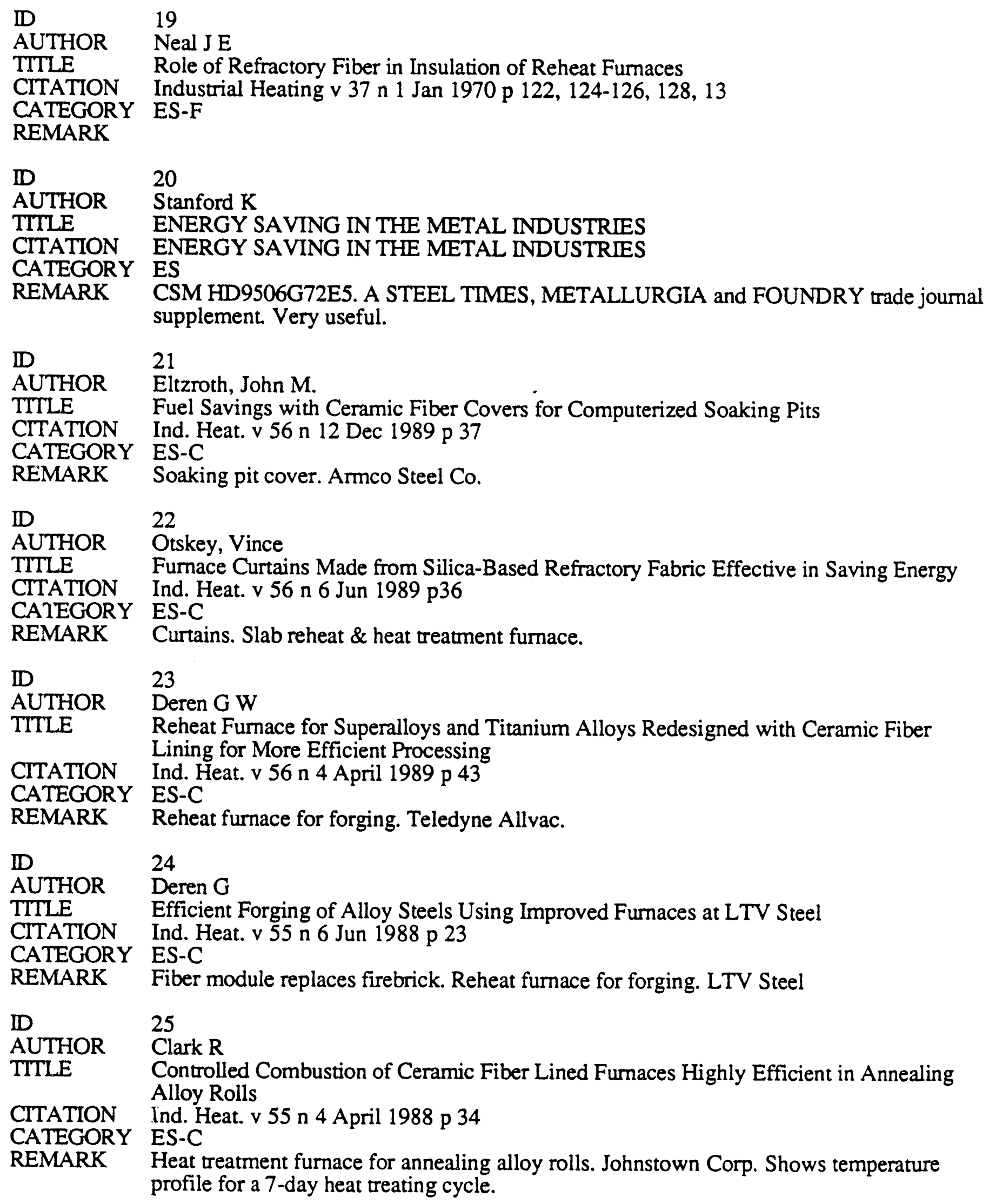




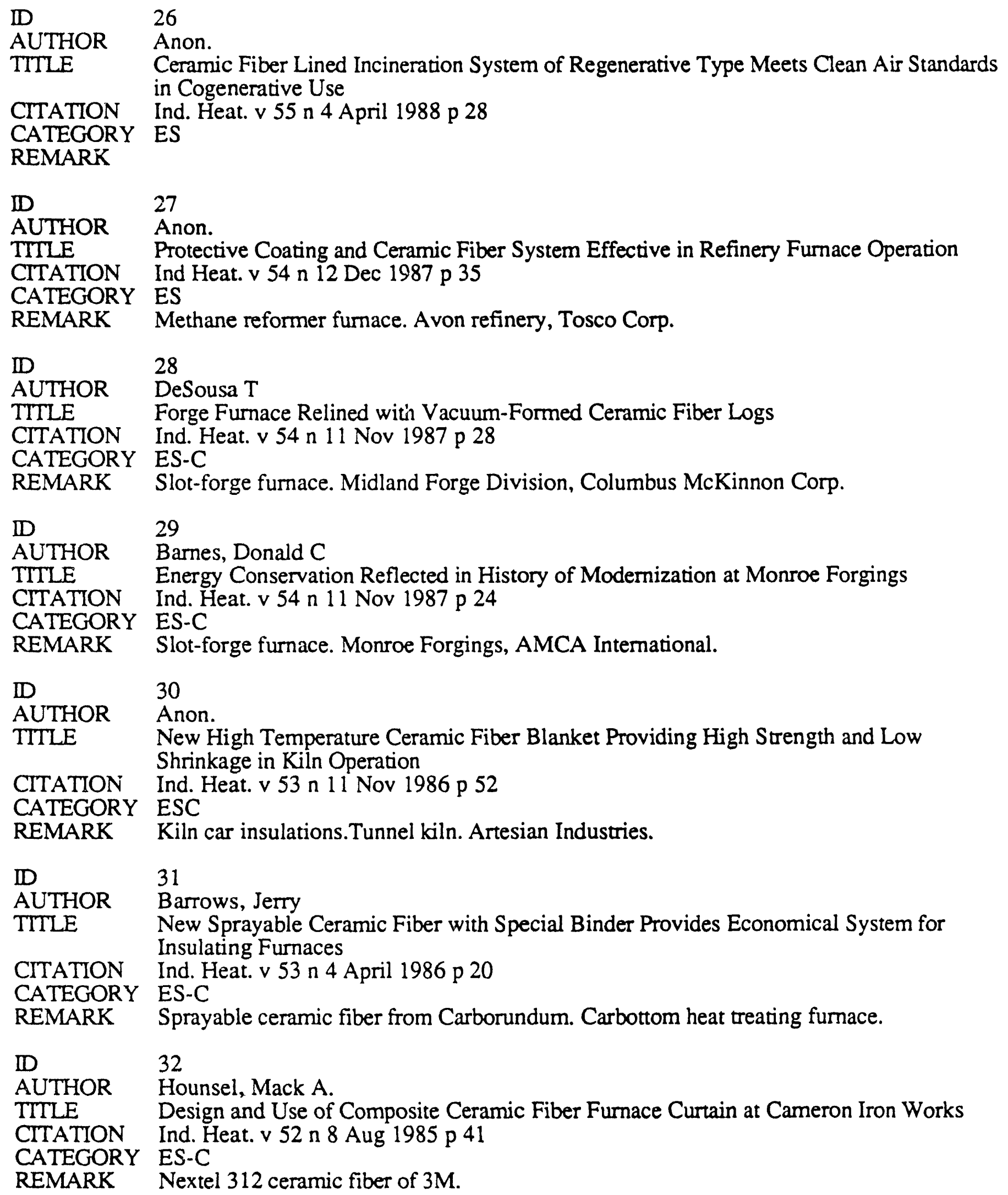




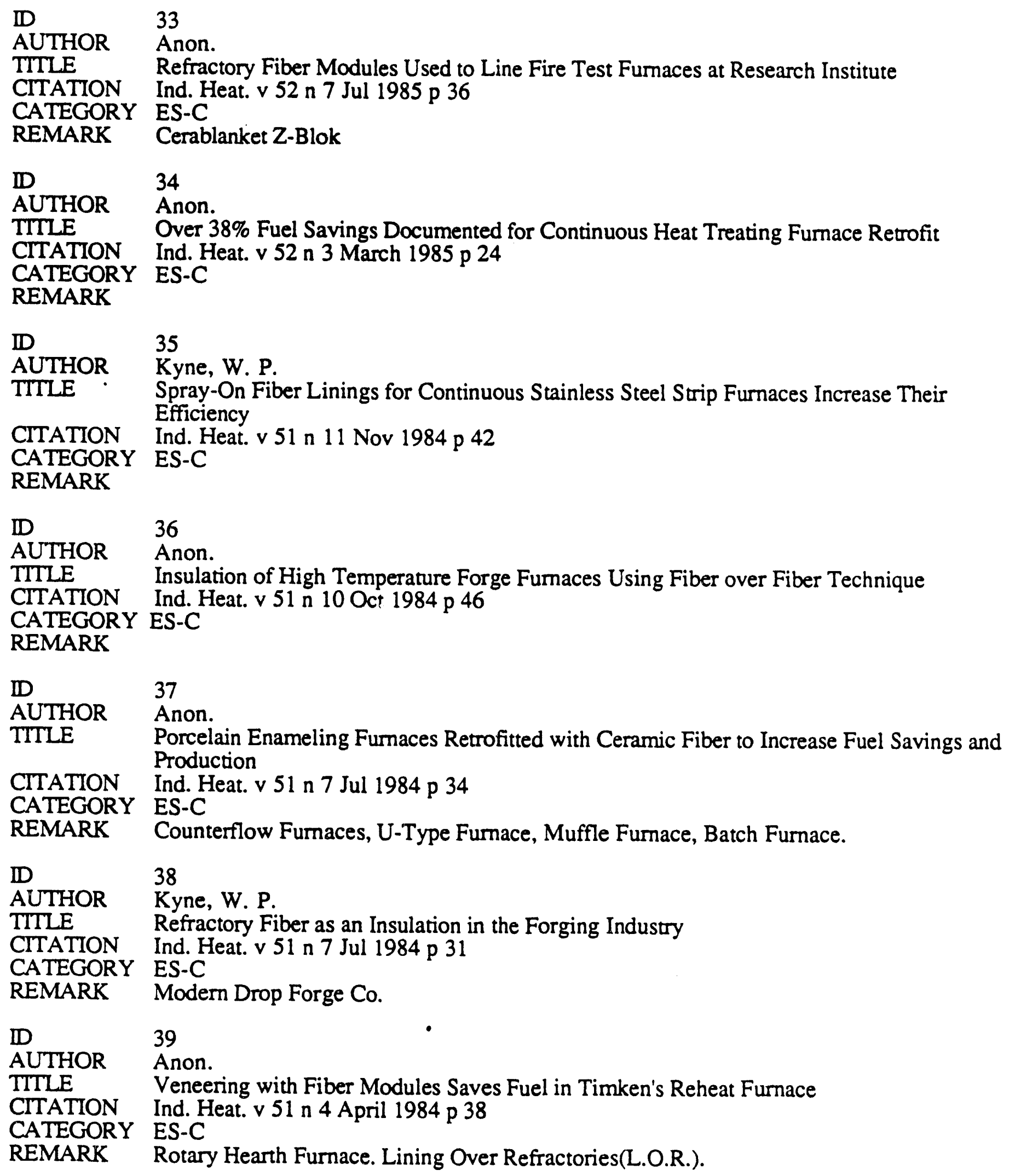




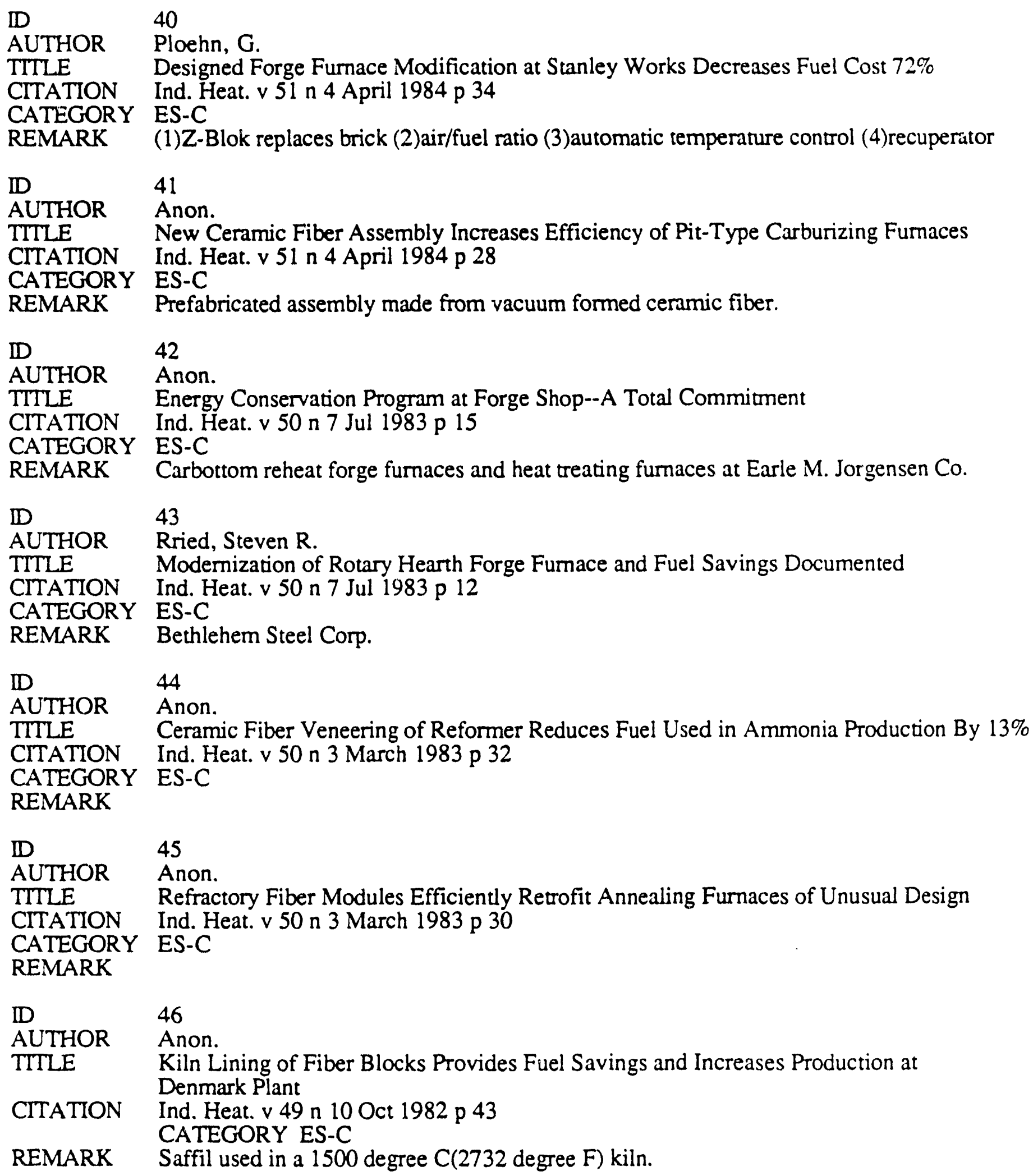




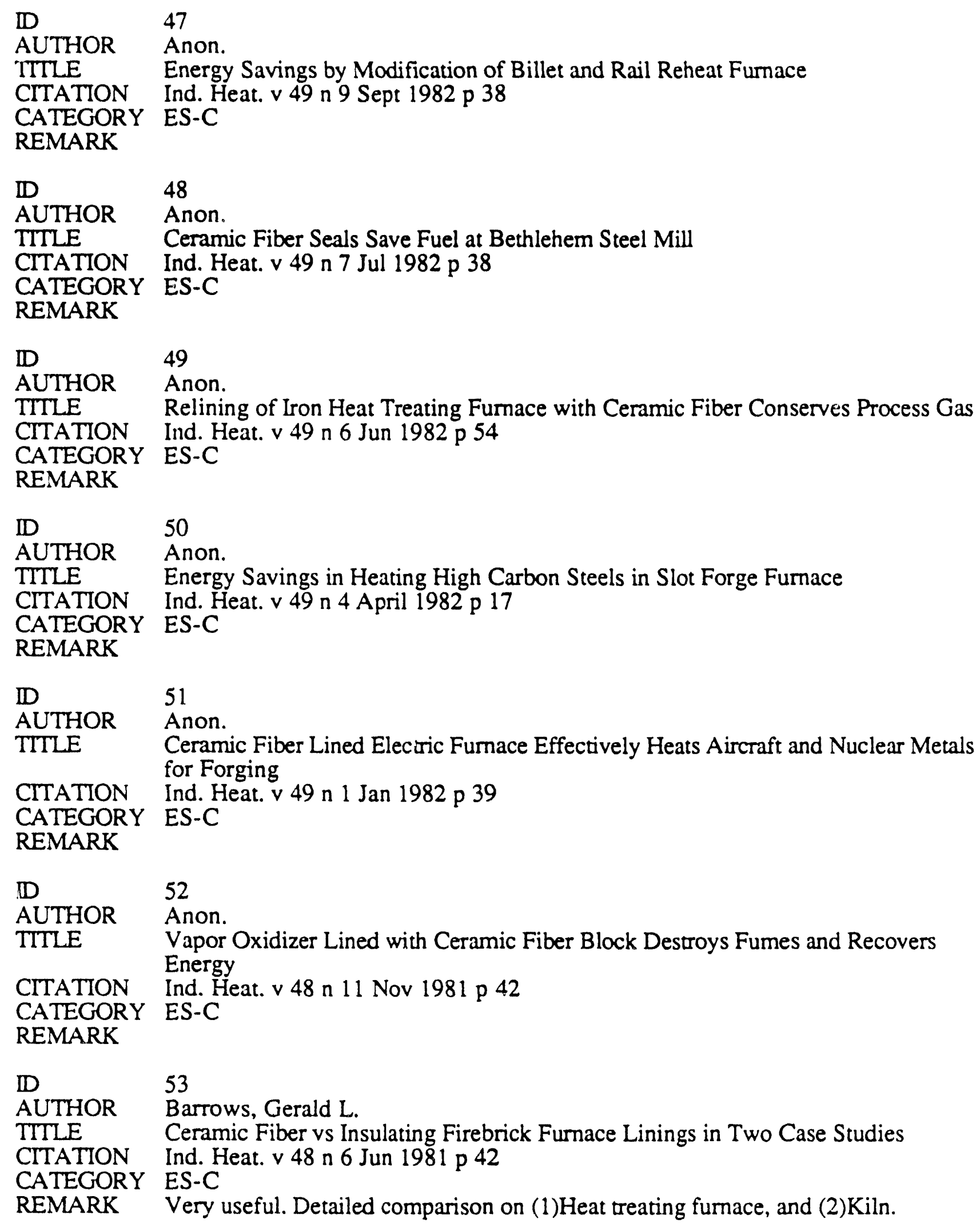




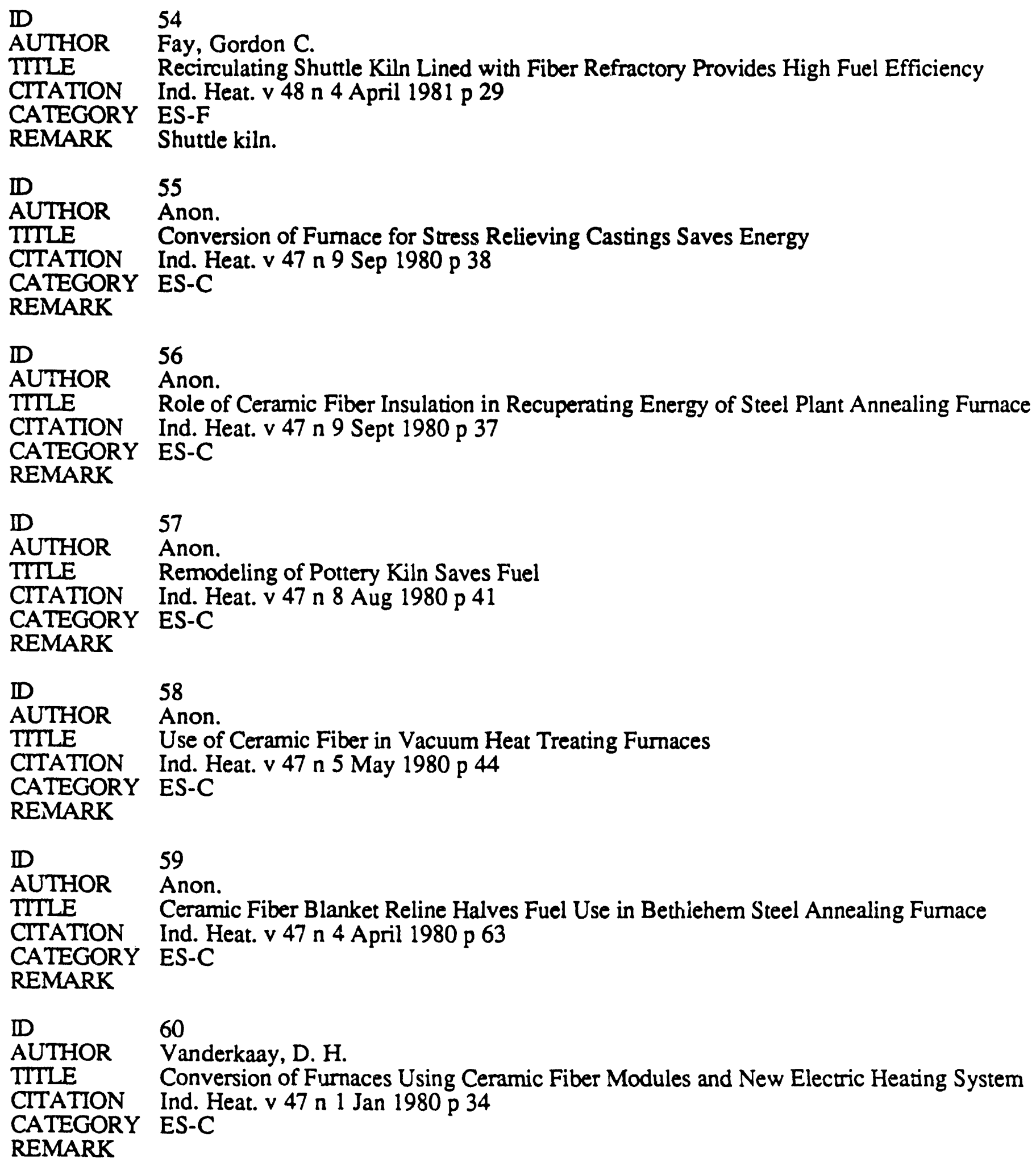




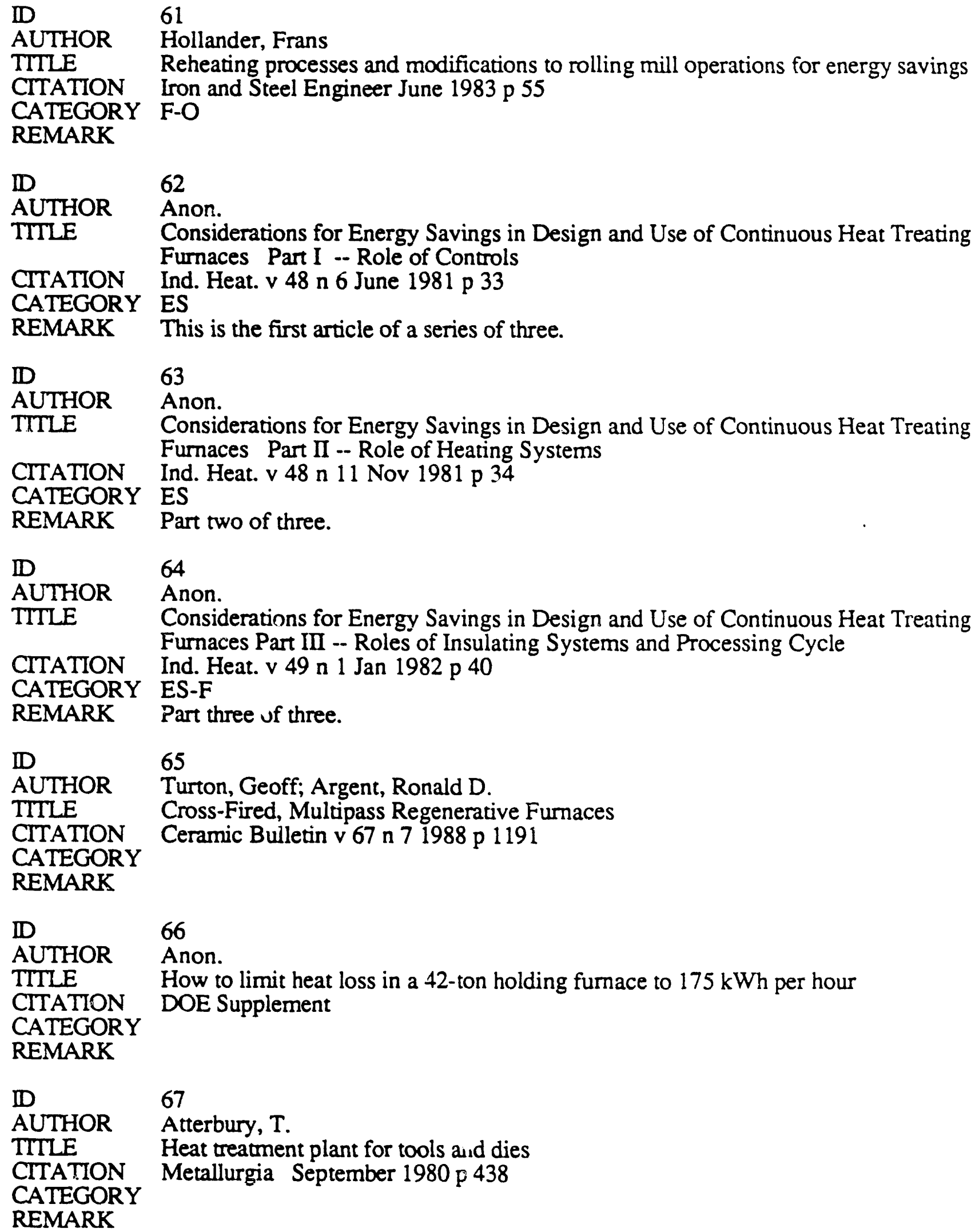




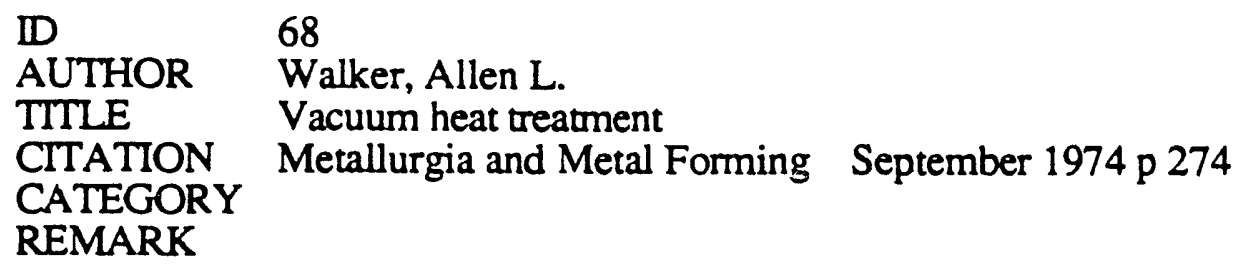

ID 69

AUTHOR Fukushima, Takeo

TITLE Recent Technological Progress in High Speed Continuous Annealing

CITATION Transactions ISIJ v 251985 p 278

CATEGORY

REMARK

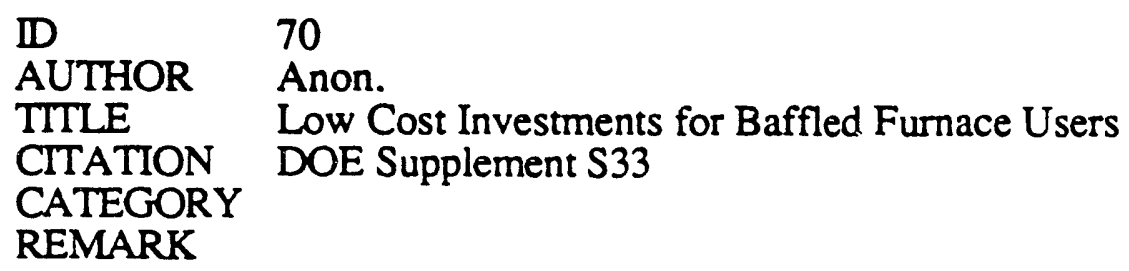

ID $\quad 72$

AUTHOR Sakano, Yoshiro; Takahashi, Hiroshi

TITLE Outlook for the Refractories Industry in Japan

CITATION Ceramic Bulletin v 67 n 71988 p 1164

CATEGORY ES

REMARK

ID 73

AUTHOR Anon.

TITLE Effectiveness of Coating Refractories for Energy Savings

CITATION Ind. Heat. v 49 n 4 April 1982 p 10

CATEGORY

REMARK

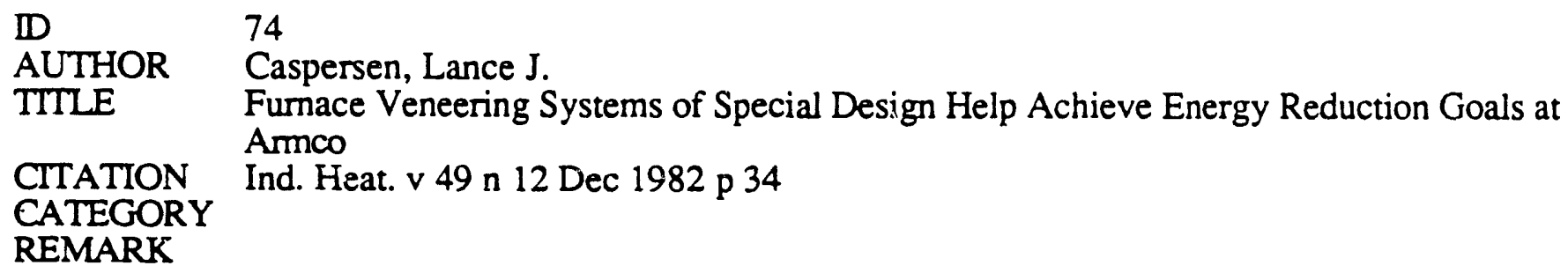


ID 75

AUTHOR Anon.

TITLE Veneering of Hugh Rotary Reheat Furnace Saves Fuel

CITATTON Ind. Heat. $v 51$ n 7 July 1984 p 32

CATEGORY

REMARK

ID 76

AUTHOR Vance, $M$. W.

TITLE Development of a Non-Welded Skid-Pipe Insulation for Steel Plant Reheat Furnaces

CITATION Ind. Heat. v 52 n 4 April 1985 p 22

CATEGORY

REMARK

ID 77

AUTHOR Ciliberto, Tony

TITLE Design and Installation of Layered Ceramic Fiber Modules for Furnace Efficiency

CITATION Ind. Heat. v $48 \mathrm{n} 4$ April 1981 p 20

CATEGORY

REMARK

ID 78

AUTHOR West, John

TITLE Retrofitting Forge Shop Furnaces for Energy Conservation

CITATION Ind. Heat. v 49 n 7 July 1982 p 26

CATEGORY

REMARK

ID 79

AUTHOR Lasday, Stanley B.

TTTLE Exemplification of Energy Savings in Heat Treating

CITATION Ind. Heat. v 47 n 8 Aug 1980

CATEGORY

REMARK

ID 80

AUTHOR Hamling, Philip

TITLE $\quad 1700 \mathrm{C}$ Rapid Cycle Furnace Insulation Design Part I - Ceramic Fiter Properties

CITATION Ind. Heat. v 55 n 4 April 1988 p 30

CATEGORY ES-F

REMARK Useful. Part one of a series of two.

ID 81

AUTHOR Hamling, Philip

TTTLE $\quad 1700 \mathrm{C}$ Rapid Cycle Fumace Insulation Design Part II - Chamber Design CITATION

CATEGORY

REMARK 


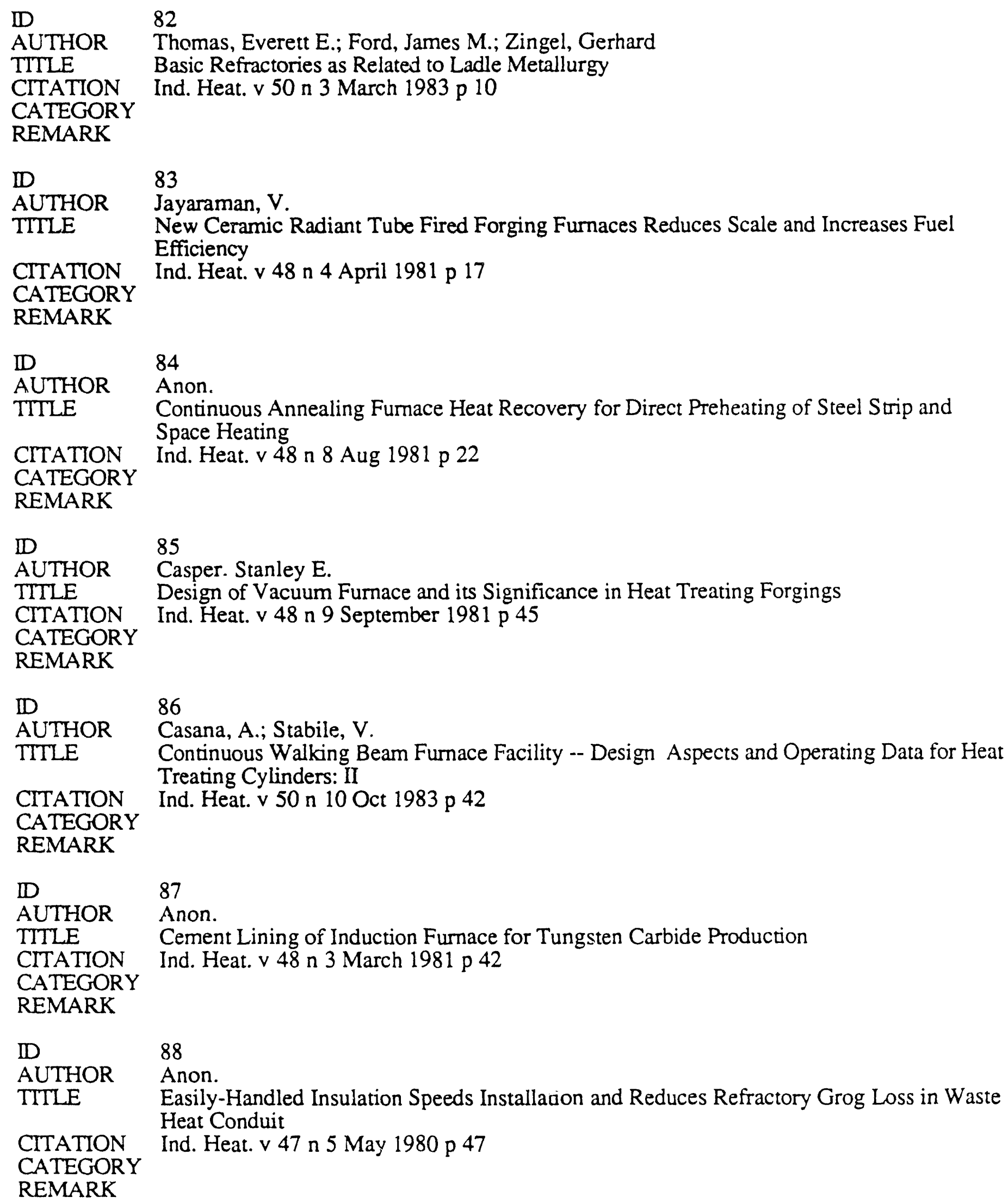




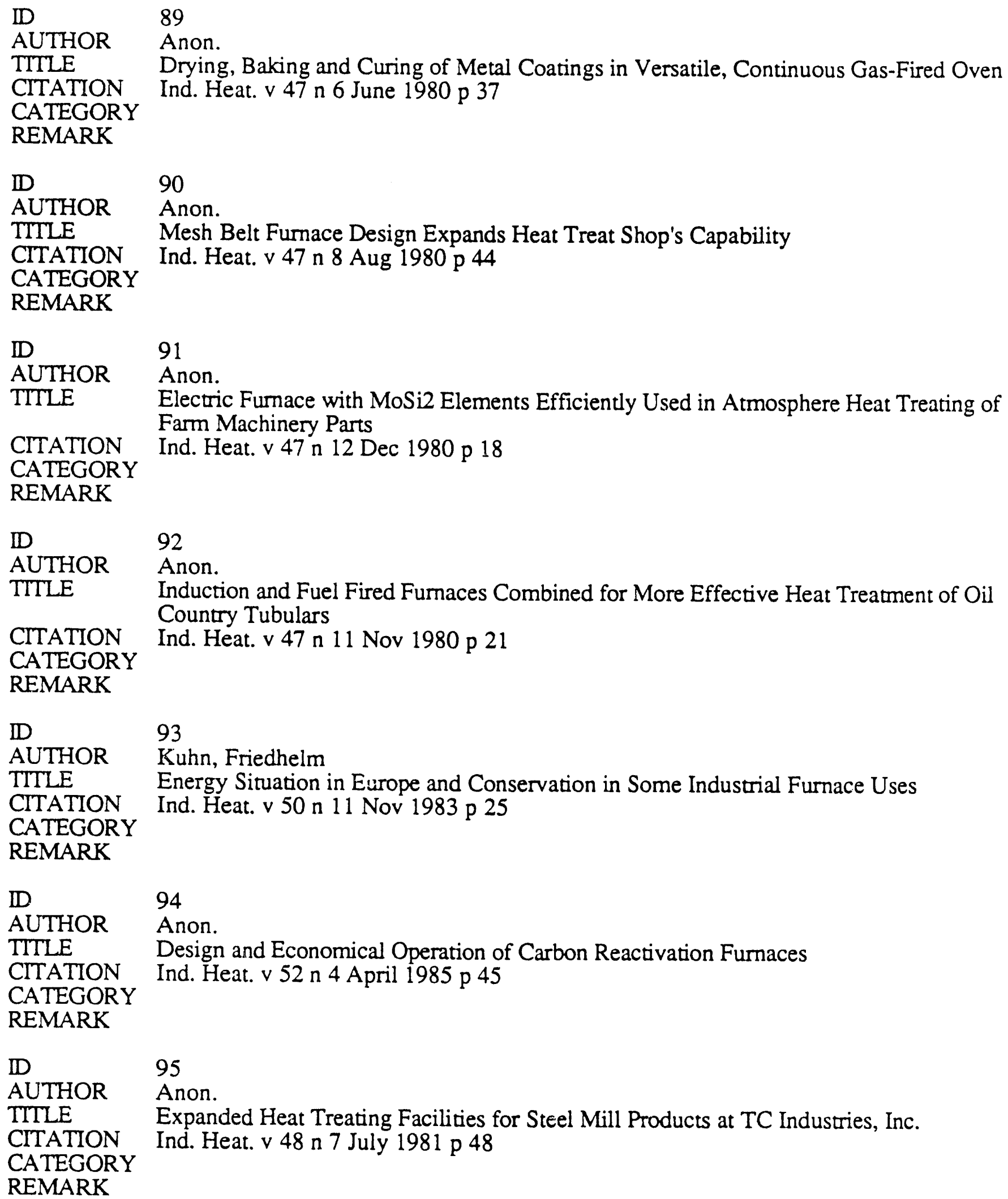




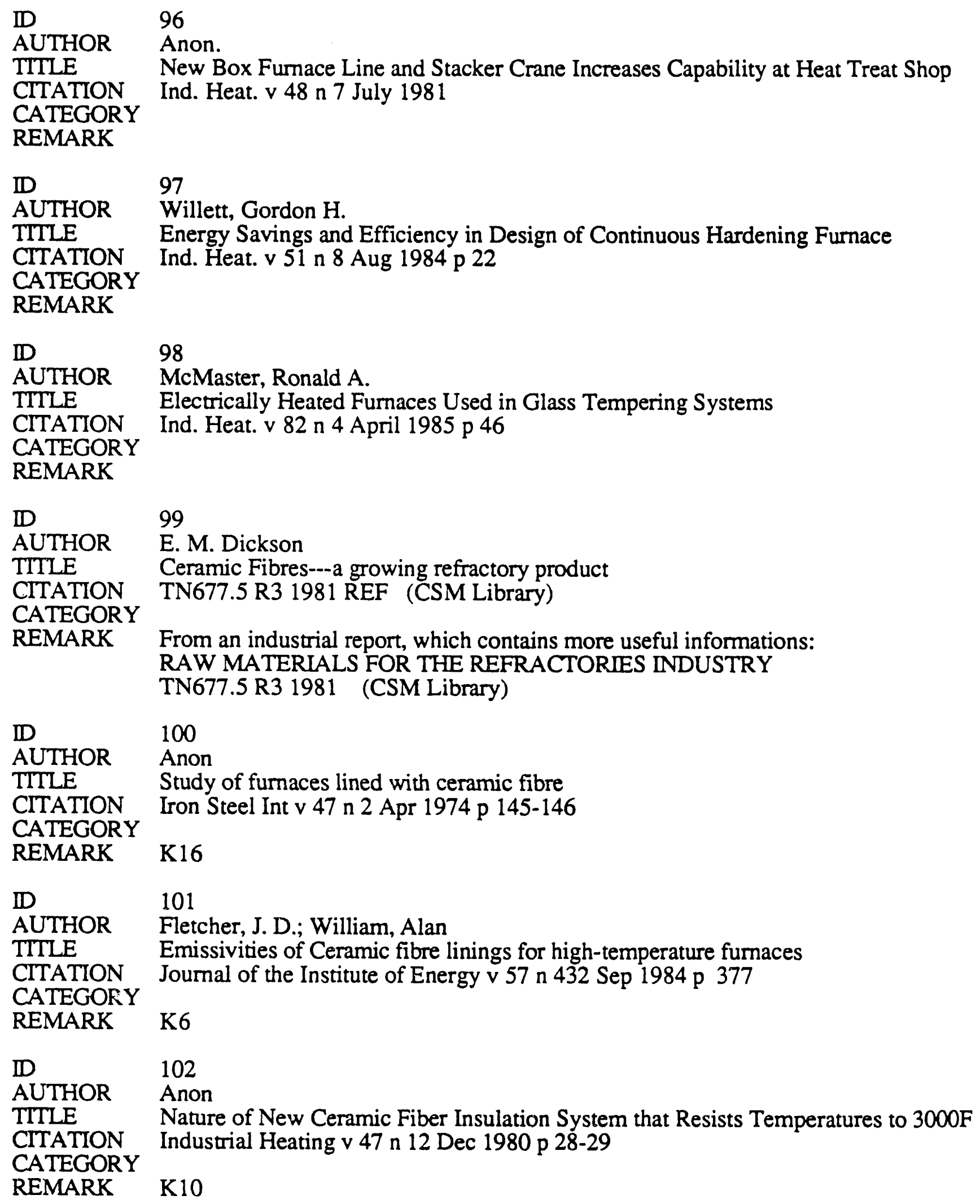




\begin{tabular}{|c|c|}
\hline $\begin{array}{l}\text { D } \\
\text { AUTHOR } \\
\text { TTTLE } \\
\text { CITATION } \\
\text { CATEGORY } \\
\text { REMARK }\end{array}$ & $\begin{array}{l}103 \\
\text { Anon } \\
\text { Installation and Economy of Ceramic Fiber Roofs for Forge Furnaces } \\
\text { Industrial Heating v } 43 \text { n } 4 \text { Apr } 1976 \text { p 33-34, 36-37 } \\
\text { K12 }\end{array}$ \\
\hline $\begin{array}{l}\text { D } \\
\text { AUTHOR } \\
\text { TITLE } \\
\text { CITATION } \\
\text { CATEGORY } \\
\text { REMARK }\end{array}$ & $\begin{array}{l}104 \\
\text { Anon } \\
\text { High Temperature Ceramic Fiber Effective in Insulating Wire Uses } \\
\text { Industrial Heating v } 49 \mathrm{n} 4 \text { April } 1982 \text { p } 24 \\
\text { IH1 }\end{array}$ \\
\hline $\begin{array}{l}\text { ID } \\
\text { AUTHOR } \\
\text { TITLE }\end{array}$ & $\begin{array}{l}105 \\
\text { Copes, Jane Snell; Smith, Robert G. } \\
\text { Microstructural Characterization of Thermally-Aged Siconex Oxide Fiber/SiC Composite } \\
\text { Materials } \\
\text { Ceram. Eng. Sci. Proc. } 8[7-8] \text { o. } 976(1987)\end{array}$ \\
\hline $\begin{array}{l}\text { CATEGORY } \\
\text { REMARK }\end{array}$ & $\begin{array}{l}\text { Ceram. Eng. Sci. Proc., } 8[7-8] \text { p. } 976(1987) \\
\text { N12 Materials Science }\end{array}$ \\
\hline $\begin{array}{l}\text { ID } \\
\text { AUTHOR } \\
\text { TITLE } \\
\text { CITATION } \\
\text { CATEGORY } \\
\text { REMARK }\end{array}$ & $\begin{array}{l}106 \\
\text { D. D. Johnson, A. R. Holtz, M. F. Grether } \\
\text { Properties of Nextel } 480 \text { Ceramic Fibers } \\
\text { Ceram. Eng. Sci. Proc., 8[7-8] pp. 744-754 (1987) } \\
\text { N13 Materials Science }\end{array}$ \\
\hline $\begin{array}{l}\text { ID } \\
\text { AUTHOR } \\
\text { TITLE } \\
\text { CITATION } \\
\text { CATEGORY } \\
\text { REMARK }\end{array}$ & $\begin{array}{l}107 \\
\text { Harold G. Sowman } \\
\text { A New Era in Ceramic Fibers via Sol-Gel Technology } \\
\text { Ceramic Bulletin, Vol 67, No. 12, } 1988 \\
\text { N4 S5 Materials Science }\end{array}$ \\
\hline $\begin{array}{l}\text { ID } \\
\text { AUTHOR } \\
\text { TITLE } \\
\text { CITATION } \\
\text { CATEGORY } \\
\text { REMARK }\end{array}$ & $\begin{array}{l}108 \\
\text { M. H. Stacey } \\
\text { Developments in Continuous Alumina-Based Fibres } \\
\text { Br. Ceram. Trans. J., 87, 168-172, 1988 } \\
\text { N5 S6 Materials Science }\end{array}$ \\
\hline $\begin{array}{l}\text { D } \\
\text { AUTHOR } \\
\text { TITLE } \\
\text { CITATION } \\
\text { CATEGORY } \\
\text { REMARK }\end{array}$ & $\begin{array}{l}109 \\
\text { S. Karlsson, R. Lundberg, R. Carlsson } \\
\text { Thermal and Environmental Effects on Ceramic Fibers } \\
\text { J. de Physique Colloque C1 suppl v } 47 \text { n2 Fem } 1986 \text { p 587-591 }\end{array}$ \\
\hline
\end{tabular}




\begin{tabular}{|c|c|}
\hline $\begin{array}{l}\text { D } \\
\text { AUTHOR } \\
\text { TITLE } \\
\text { CITATION } \\
\text { CATEGORY } \\
\text { REMARK }\end{array}$ & $\begin{array}{l}110 \\
\text { Anon } \\
\text { Why a high alumina fibre lining can be money well spent } \\
\text { Iron and Steel International v } 53 \mathrm{n} 2 \mathrm{Apr} 1980 \mathrm{p} 105-106\end{array}$ \\
\hline $\begin{array}{l}\text { D } \\
\text { AUTHOR } \\
\text { TITLE } \\
\text { CITATION } \\
\text { CATEGORY } \\
\text { REMARK }\end{array}$ & $\begin{array}{l}111 \\
\text { T. Kokubo, Y. Teranishi, T. Maski, S. Sakka } \\
\text { Formation of Zirconia fobres on unidirectional freezing of a gel } \\
\text { Journal of Materials Science } 23 \text { (1988) 1126-1130 } \\
\text { Z15 Materials Science }\end{array}$ \\
\hline $\begin{array}{l}\text { DD } \\
\text { AUTHOR } \\
\text { TITLE } \\
\text { CITATION } \\
\text { CATEGORY } \\
\text { REMARK }\end{array}$ & $\begin{array}{l}112 \\
\text { Sivananda S. Jada } \\
\text { Surface properties of gel-derived zirconia fibres } \\
\text { Journal of Materials Science Letters } 6 \text { (1987) 1368-1370 } \\
\text { Z17 Materials Science }\end{array}$ \\
\hline $\begin{array}{l}\text { ID } \\
\text { AUTHOR } \\
\text { TITLE } \\
\text { CITATION } \\
\text { CATEGORY } \\
\text { REMARK }\end{array}$ & $\begin{array}{l}113 \\
\text { James C. Romine } \\
\text { New High-Temperature Ceramic Fiber } \\
\text { Ceram. Eng. Sci. Proc., } 8[7-8] \text { pp. } 755-765 \text { (1987) } \\
\text { Z30 Materials Science }\end{array}$ \\
\hline $\begin{array}{l}\text { ID } \\
\text { AUTHOR } \\
\text { TITLE } \\
\text { CITATION } \\
\text { CATEGORY } \\
\text { REMARK }\end{array}$ & $\begin{array}{l}114 \\
\text { David B. Marshall, F. F. Lange, Peter D. Morgan } \\
\text { High-Strength Zirconia Fibers } \\
\text { J. Am. Ceram. Soc. v } 70 \text { n } 8 \text { Aug } 1987 \text { p C187-C188 } \\
\text { Z32 Materials Science }\end{array}$ \\
\hline $\begin{array}{l}\text { ID } \\
\text { AUTHOR } \\
\text { TTTLE }\end{array}$ & $\begin{array}{l}115 \\
\text { L. K. Matthews, R. Viskanta, F. P. Incropera } \\
\text { Development of Methods for Determining Thermophysical and Radiative Properties of } \\
\text { High-temperature Fibrous Materials }\end{array}$ \\
\hline $\begin{array}{l}\text { CITATION } \\
\text { CATEGORY } \\
\text { REMARK }\end{array}$ & $\begin{array}{l}\text { Int. J. Heat Mass Transfer. v } 27 \text { n } 4 \text { p } 487-495,1984 \\
\text { Z79 }\end{array}$ \\
\hline $\begin{array}{l}\text { ID } \\
\text { AUTHOR } \\
\text { TITLE } \\
\text { CITATION } \\
\text { CATEGORY } \\
\text { REMARK }\end{array}$ & $\begin{array}{l}116 \\
\text { J. D. Birchall } \\
\text { The Preparation and Properties of Polycrystalline Aluminium Oxide Fibres } \\
\text { Proc. Br. Ceram. Soc., 33(Fabr. Sci. 3), 51-62 }\end{array}$ \\
\hline
\end{tabular}




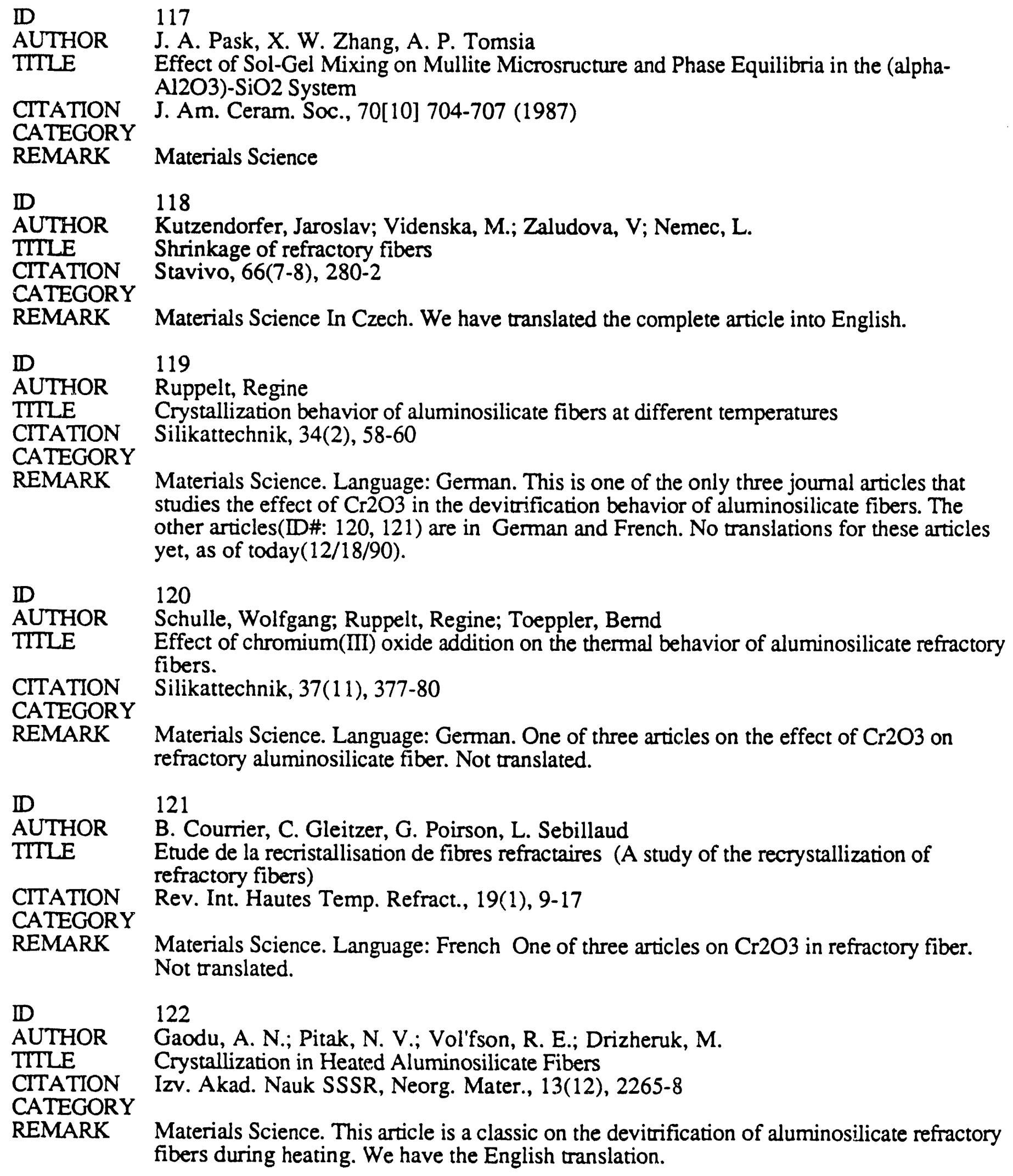




\begin{tabular}{|c|c|}
\hline $\begin{array}{l}\text { D } \\
\text { AUTHOR } \\
\text { TITLE } \\
\text { CITATION } \\
\text { CATEGORY }\end{array}$ & $\begin{array}{l}123 \\
\text { S. M. Ohlberg, D. W. Strickler } \\
\text { Determination of Percent Crystallinity of Partly Devitrified Glass by X-Ray Diffraction } \\
\text { J. Am. Ceram. Soc., } 45 \text { [4] 170-71 (1962) }\end{array}$ \\
\hline REMARK & $\begin{array}{l}\text { Materials Science. \% crystallinity of partly devitrified glass }=100\left(\mathrm{I}-\mathrm{I}^{\prime}\right) /(\mathrm{I}-\mathrm{I} ") \text { Applicable } \\
\text { when the normalized amorphous profile is unchanged. }\end{array}$ \\
\hline $\begin{array}{l}\text { D } \\
\text { AUTHOR } \\
\text { TITLE }\end{array}$ & $\begin{array}{l}124 \\
\text { C. Mai, H. Satha, G. Thollet, G. Vigier } \\
\text { SAXS, WAXD and TEM of the Early Stages of Crystallization in TiO2-ZrO2-MgO-Li2O- } \\
\text { A12O3-SiO2 Glass }\end{array}$ \\
\hline $\begin{array}{l}\text { CITATION } \\
\text { CATEGORY }\end{array}$ & Journal of Non-Crystalline Solids 108 (1989) 201-206 \\
\hline REMARK & Materials Science. SAXS and TEM on glass. \\
\hline $\begin{array}{l}\text { D } \\
\text { AUTHOR } \\
\text { TITLE } \\
\text { CITATION } \\
\text { CATEGORY }\end{array}$ & $\begin{array}{l}125 \\
\text { P. Pernice, A. Aronne, A. Costantini, A. Marotta } \\
\text { Crystal Nucleation and Growth in an LiNaSiO3 Glass } \\
\text { Thermochimica Acta, } 159 \text { (1990) 299-304 }\end{array}$ \\
\hline REMARK & Materials Science \\
\hline $\begin{array}{l}\text { DD } \\
\text { AUTHOR } \\
\text { TTTLE } \\
\text { CITATION } \\
\text { CATEGORY }\end{array}$ & $\begin{array}{l}126 \\
\text { Guy E. Rindone } \\
\text { Further Studies of the Crystallization of a Lithium Silicate Glass } \\
\text { J. Am. Ceram. Soc. v } 45 \mathrm{n} 1 \text { Jan p } 7-12 \text { (1962) }\end{array}$ \\
\hline REMARK & Materials Science \\
\hline $\begin{array}{l}\text { D } \\
\text { AUTHOR } \\
\text { TITLE } \\
\text { CTTATION } \\
\text { CATEGOR' }\end{array}$ & $\begin{array}{l}127 \\
\text { Charles L. Booth, Guy E. Rindone } \\
\text { Surface Nucleation and Crystal Orientation in Lithium Silicate Glass Fibers } \\
\text { J. Am. Ceram. Soc. v } 47 \text { n } 1 \text { Jan p 25-29 (1964) }\end{array}$ \\
\hline REMARK & Materials Science \\
\hline $\begin{array}{l}\text { D } \\
\text { AUTHOR } \\
\text { TITLE } \\
\text { CITATION } \\
\text { CATEGORY }\end{array}$ & $\begin{array}{l}128 \\
\text { Biao Yuan, Quan-Qing Chen, Min-Quan Wang } \\
\text { Crystallization and properties of Li-Al-B-Ti-silicate system glass-ceramic fibres } \\
\text { J. Materials Science } 24 \text { (1989) 4488-4494 }\end{array}$ \\
\hline REMARK & $\begin{array}{l}\text { Materials Science. Glass-ceramic fibres are studied with DTA, XRD, TEM, and SEM. } \\
\text { Sizes of microstructure and surface microcracks are examined. }\end{array}$ \\
\hline $\begin{array}{l}\text { D } \\
\text { AUTHOR } \\
\text { TITLE }\end{array}$ & $\begin{array}{l}129 \\
\text { Zou, Xuelu; Yamane, Masayuki; Li, Jiazhi; Wang, Chengyu } \\
\text { Effect of Phase Separation on Nucleation and Growth of Magnesium-Aluminium-Titanate } \\
\text { Crystals in MgO-Al2O3-SiO2-TiO2 Glass }\end{array}$ \\
\hline $\begin{array}{l}\text { CITATION } \\
\text { CATEGORY } \\
\text { REMARK }\end{array}$ & J. Non-Crystalline Solids $112(1989)$ 268-271 \\
\hline
\end{tabular}




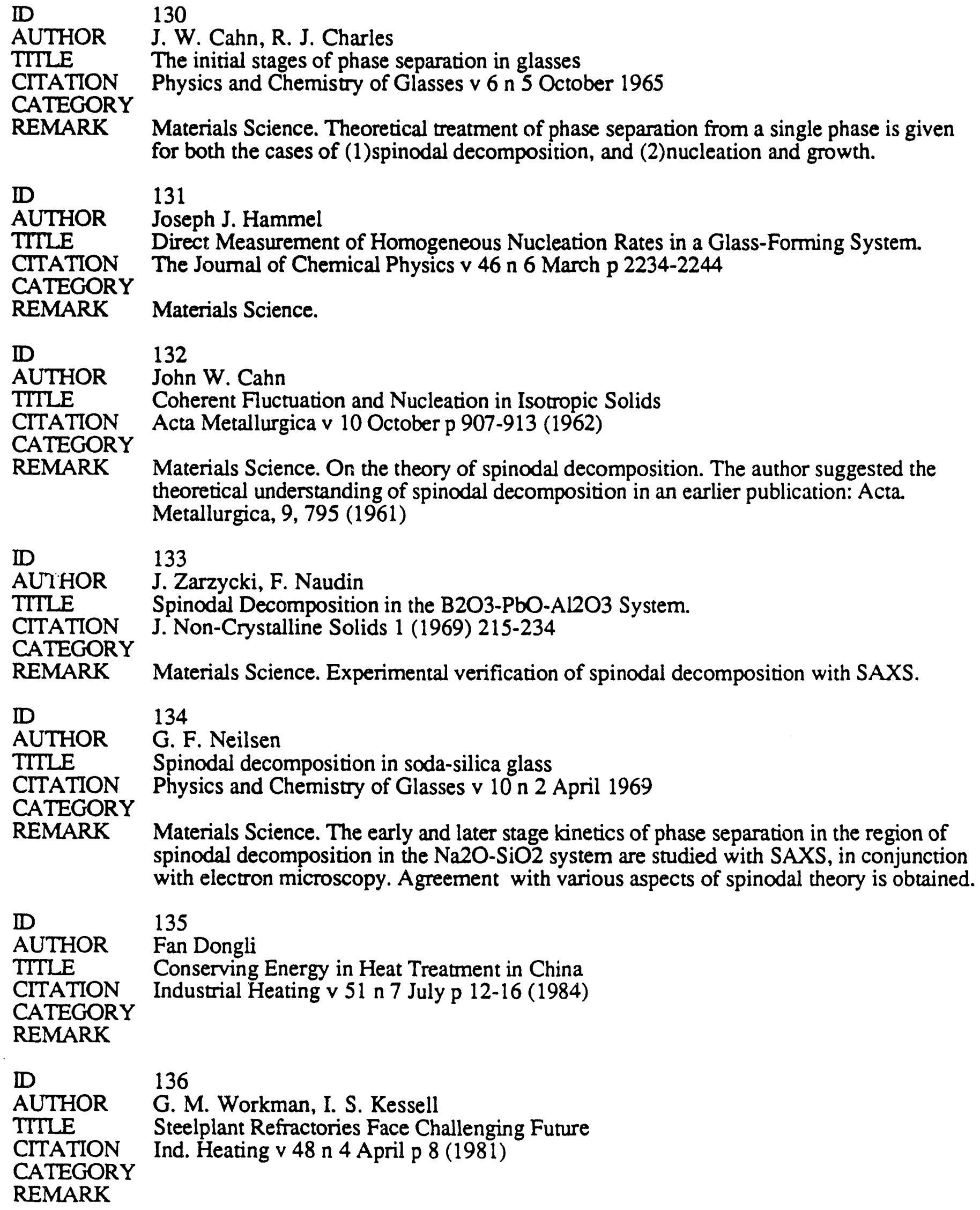




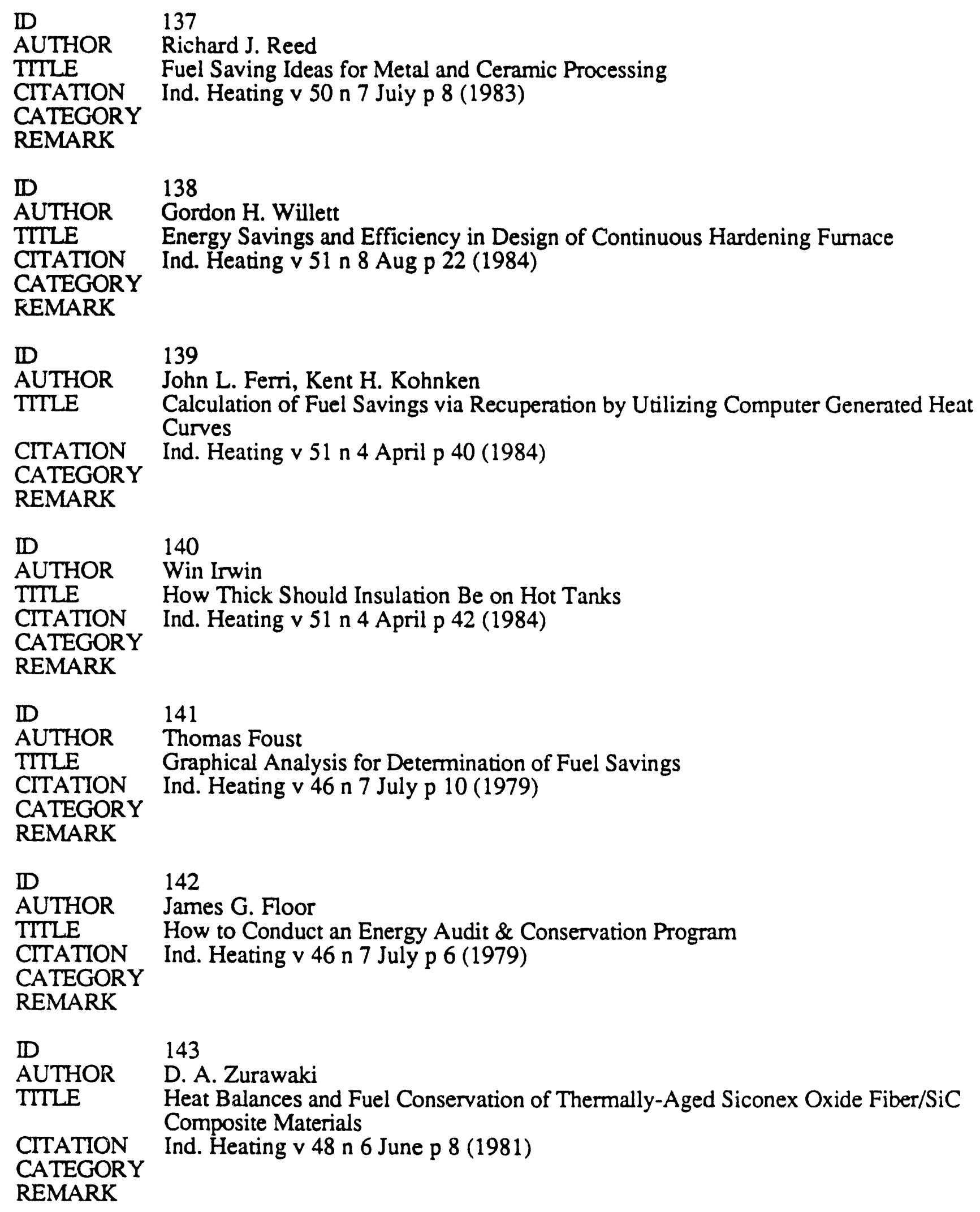




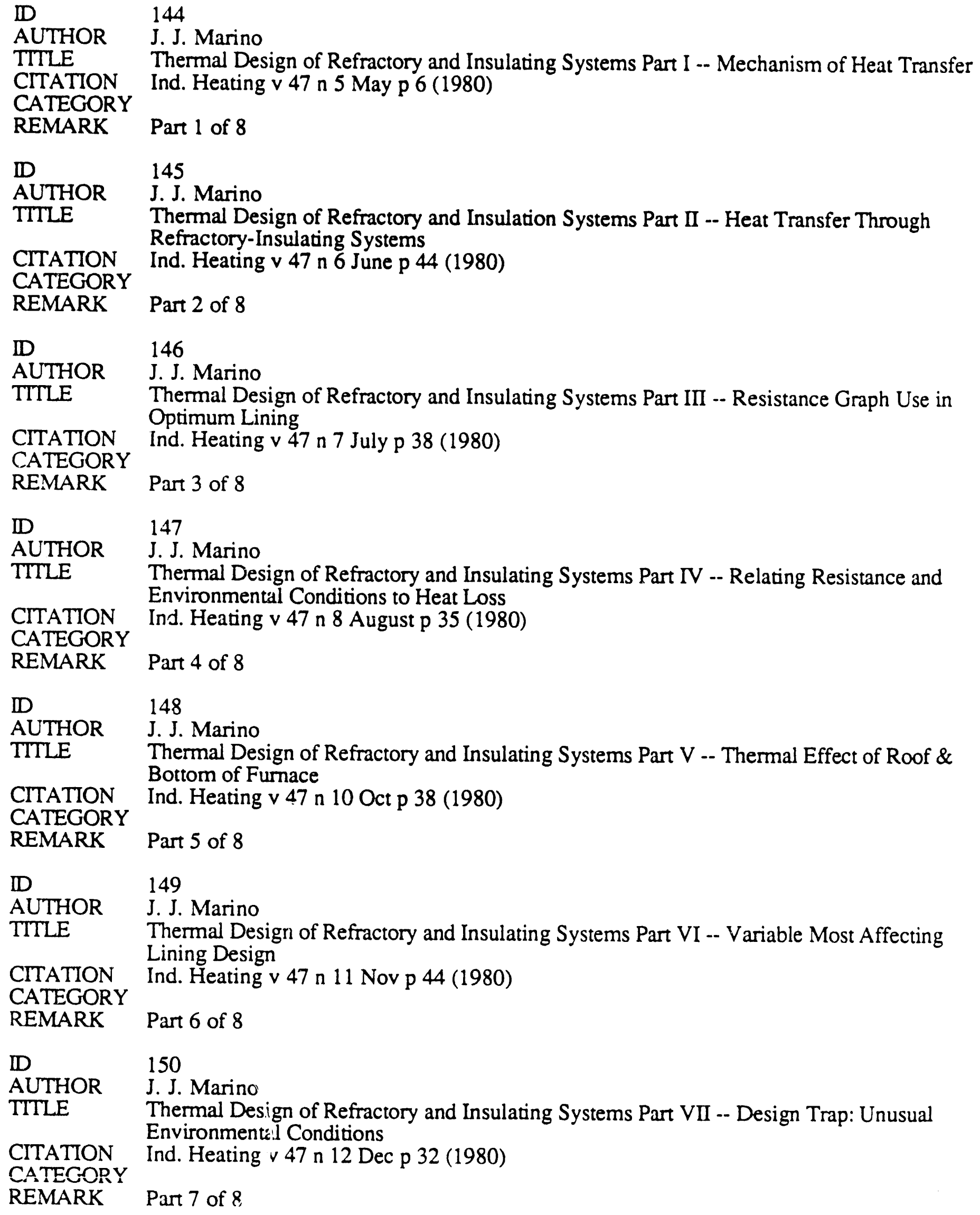




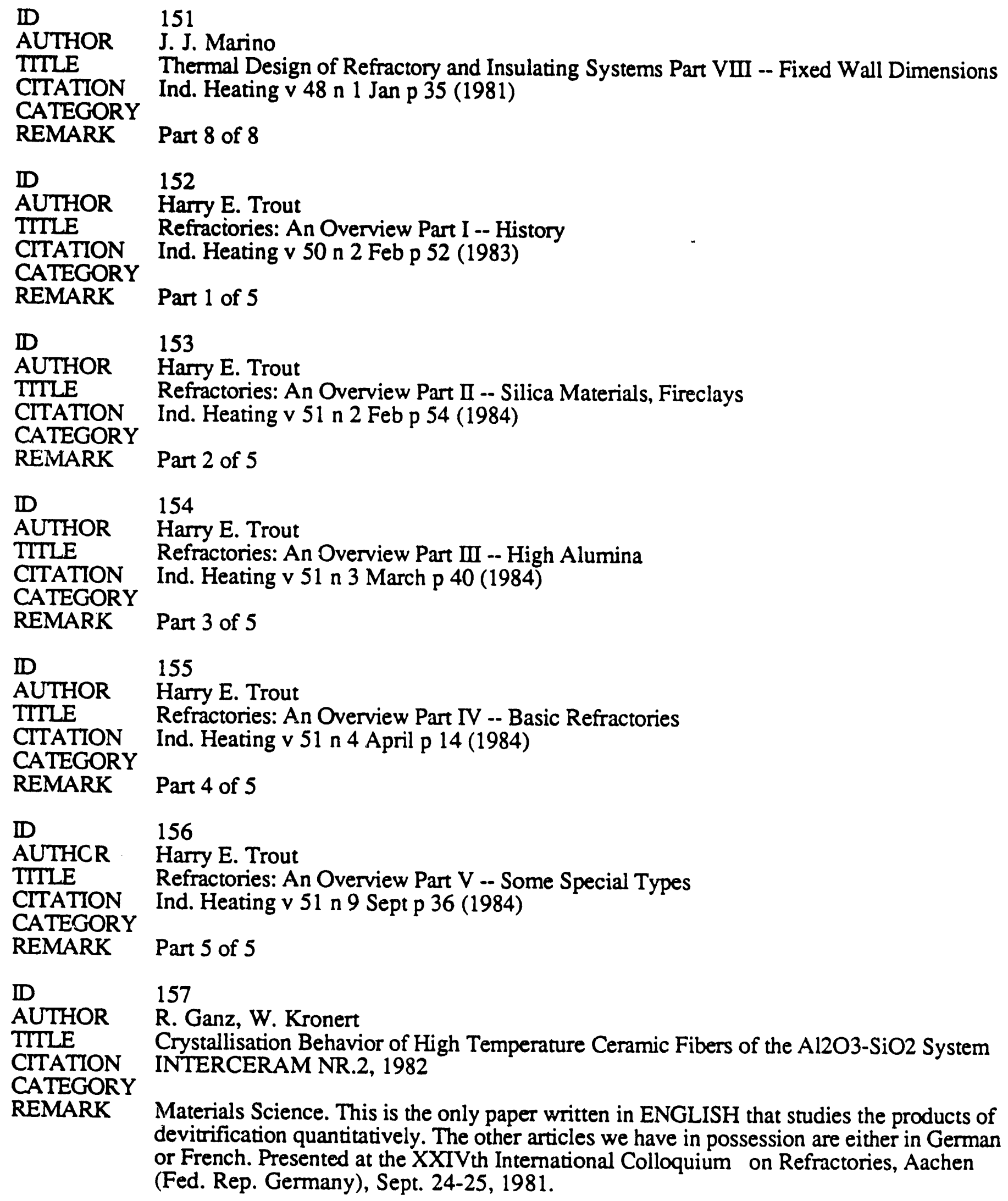

Materials Science. This is the only paper written in ENGLISH that studies the products of devitrification quantitatively. The other articles we have in possession are either in German or French. Presented at the XXIVth International Colloquium on Refractories, Aachen (Fed. Rep. Germany), Sept. 24-25, 1981. 


\begin{tabular}{|c|c|}
\hline $\begin{array}{l}\text { DD } \\
\text { AUTHOR } \\
\text { TTTLE } \\
\text { CITATION } \\
\text { CATEGORY } \\
\text { REMARK }\end{array}$ & $\begin{array}{l}158 \\
\text { D. G. LeGrand } \\
\text { Small-Angle X-Ray and Neutron Scattering }\end{array}$ \\
\hline $\begin{array}{l}\text { ID } \\
\text { AUTHOR } \\
\text { TITLE } \\
\text { CITATION } \\
\text { CATEGORY } \\
\text { REMARK }\end{array}$ & $\begin{array}{l}159 \\
\text { Jerome D. Wisnosky, Ray.mond C. Kent } \\
\text { Techniques for Testing the Refractory Behaviour of Inorganic Fiber } \\
\text { Am. Ceram. Soc. Bulletin v } 55 \text { n } 11 \text { p } 989 \text { (1976) } \\
\text { Materials Science. }\end{array}$ \\
\hline $\begin{array}{l}\text { D } \\
\text { AUTHOR } \\
\text { TITLE } \\
\text { CITATION } \\
\text { CATEGOKY } \\
\text { REMARK }\end{array}$ & $\begin{array}{l}160 \\
\text { B. A. Scowcroft, G. C. Padgett } \\
\text { 3. -- The Structure and Thermal Behaviour of Ceramic Fibre Blankets } \\
\text { Trans. Br. Ceram. Soc. v } 72 \text { p } 11-14 \text { (1973) } \\
\text { Materials Science. }\end{array}$ \\
\hline $\begin{array}{l}\text { ID } \\
\text { AUTHOR } \\
\text { TITLE } \\
\text { CITATION } \\
\text { CATEGORY } \\
\text { REMARK }\end{array}$ & $\begin{array}{l}161 \\
\text { A. E. Pickles, E. Norcross } \\
\text { 38. -- Lightweight Kilns - A New Development } \\
\text { Trans. Br. Ceram. Soc. v } 73 \text { p } 239 \text { (1974) }\end{array}$ \\
\hline
\end{tabular}




\section{APPENDIX A.2 \\ X-RAY DIFFRACTION PATTERNS AFTER HEAT TREATMENT}

A.2.1 


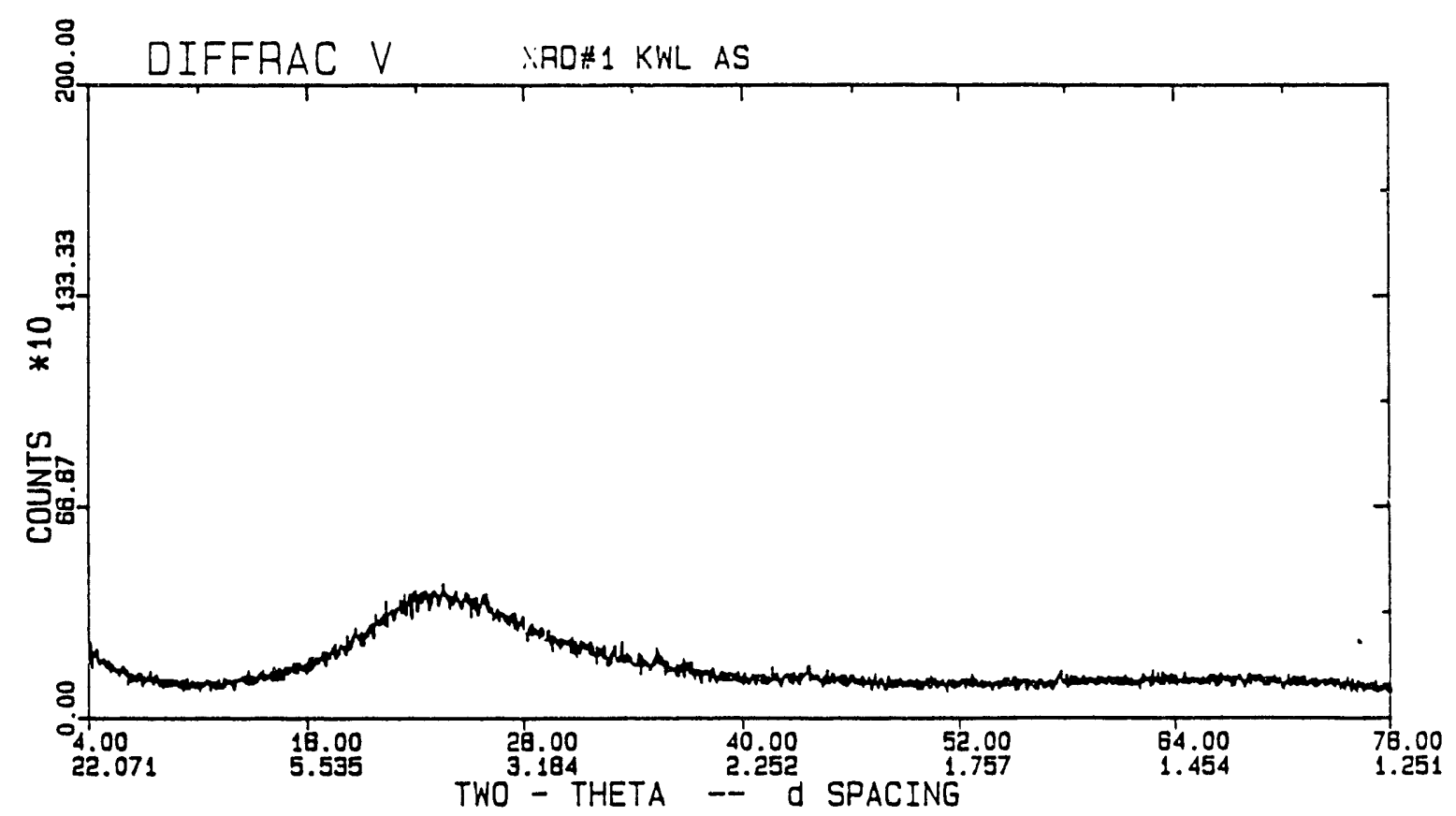

KAOWOOL 2600 - AS RECEIVED

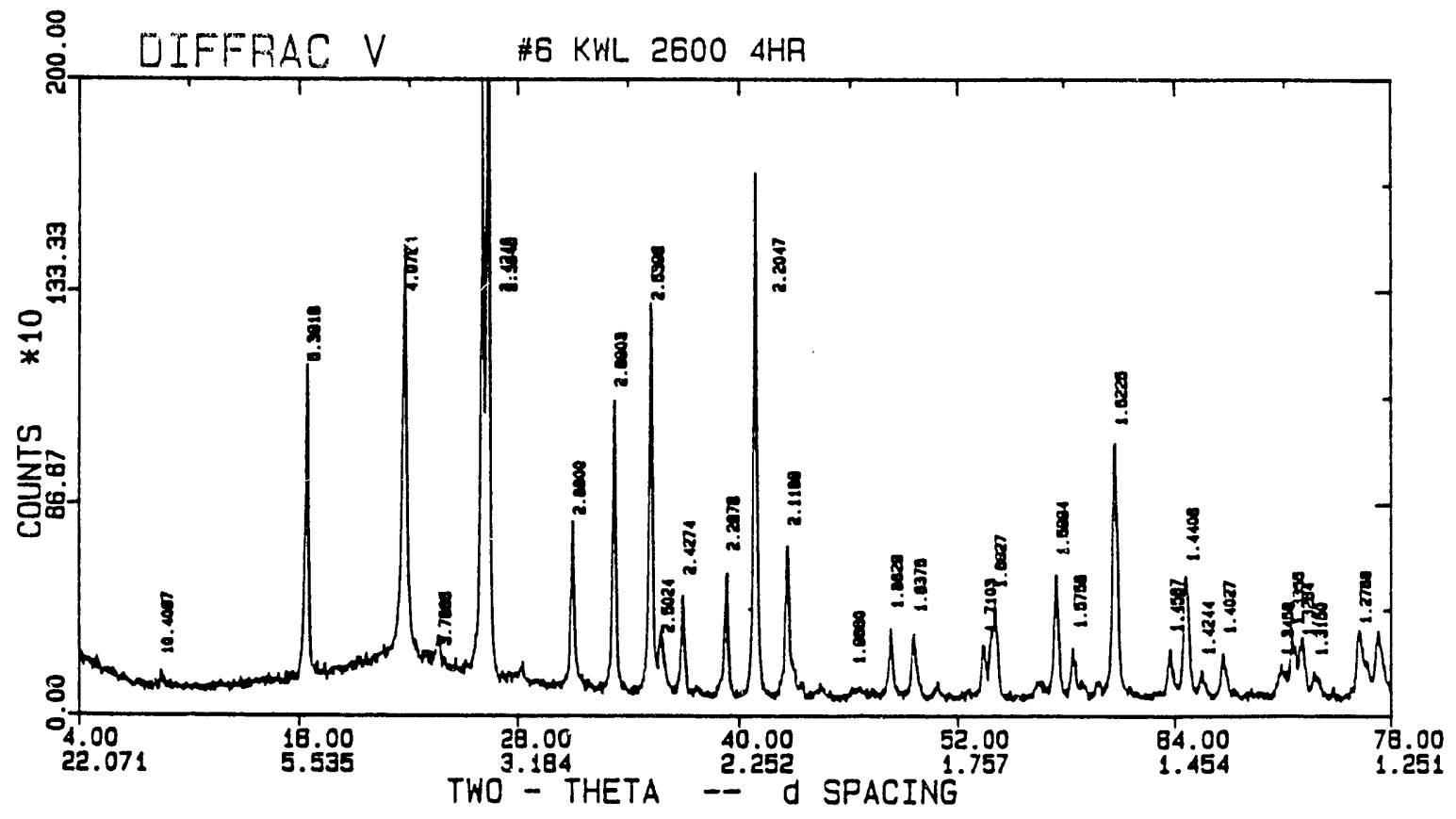

KAOWOOL 2600 - AFTER 4 HOURS@2600\% 


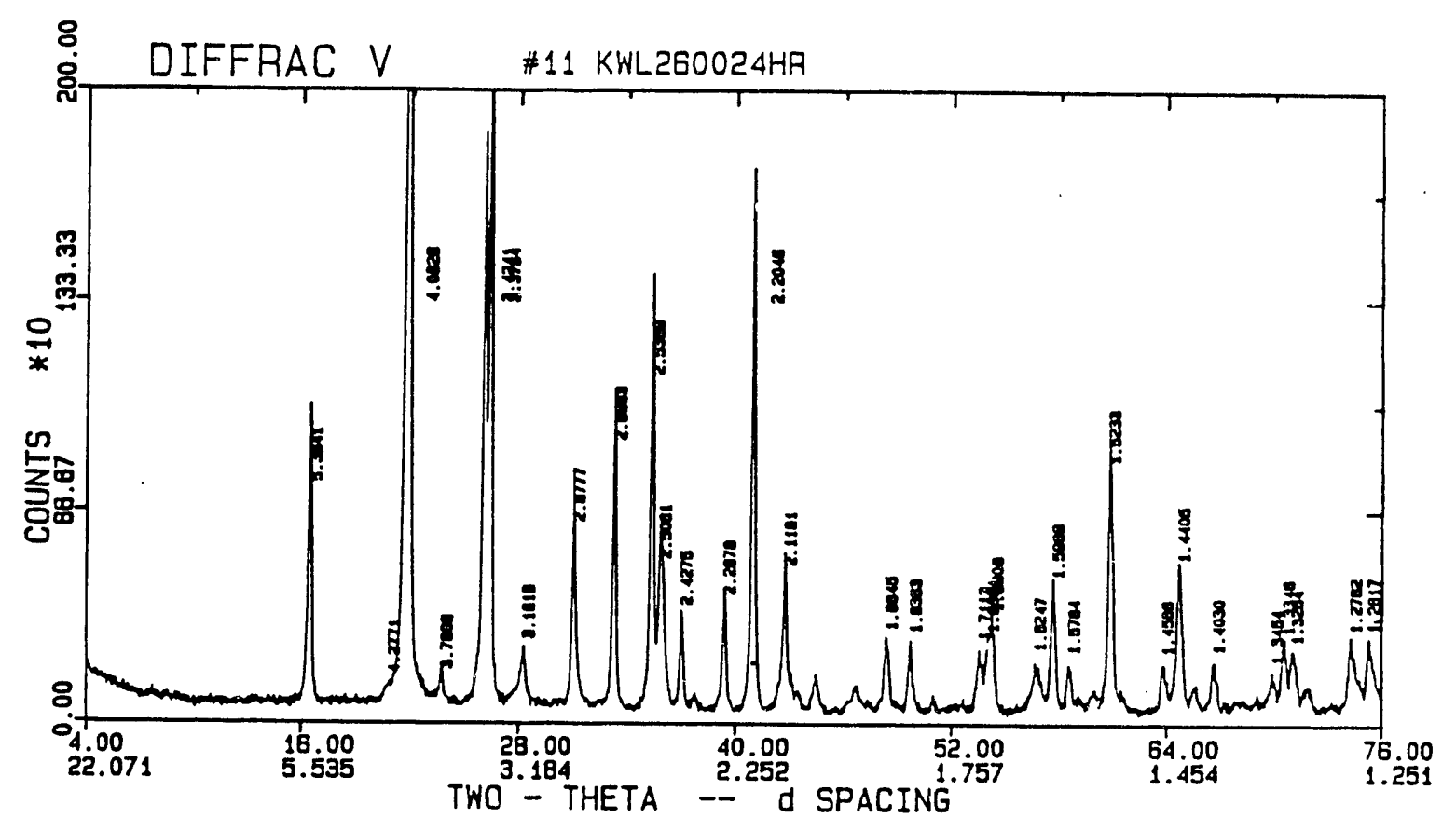

KAOWOOL 2600 . AFTER 24 HOURS@ 2600 ${ }^{\circ} \mathrm{F}$

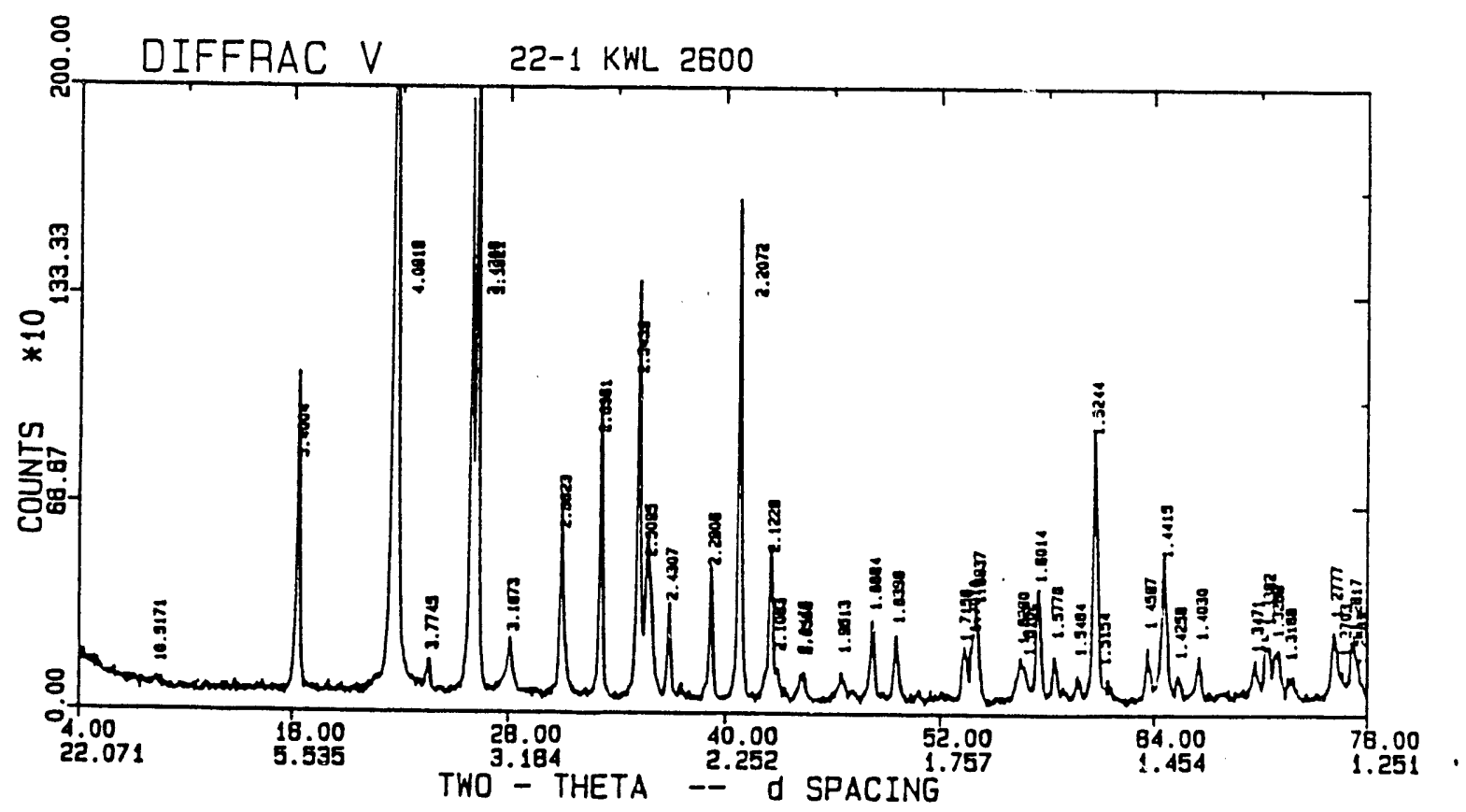

KAOWOOL 2600 - AFTER 168 HOURS@2600 


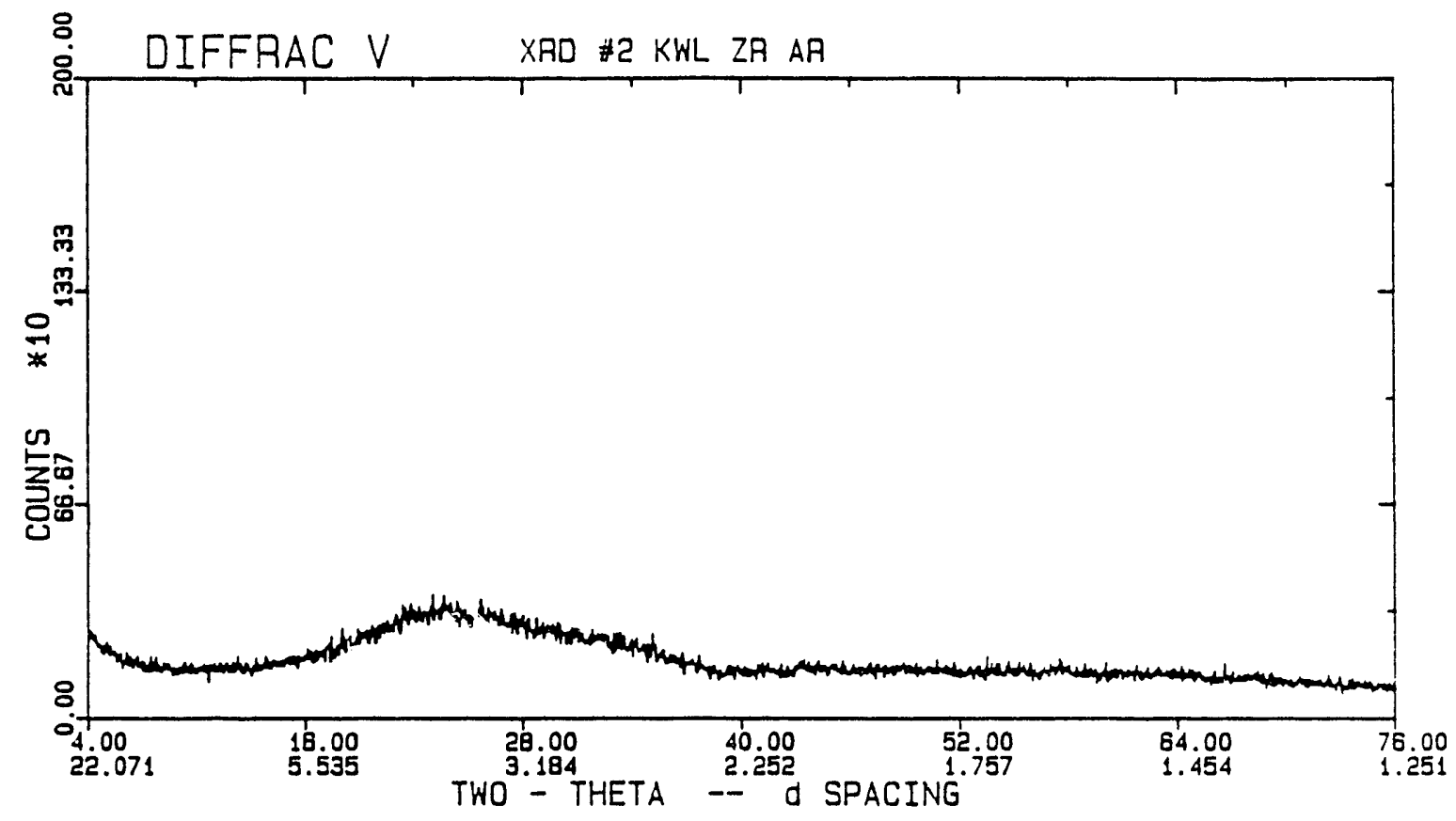

KAOWOOL ZR - AS RECEIVED

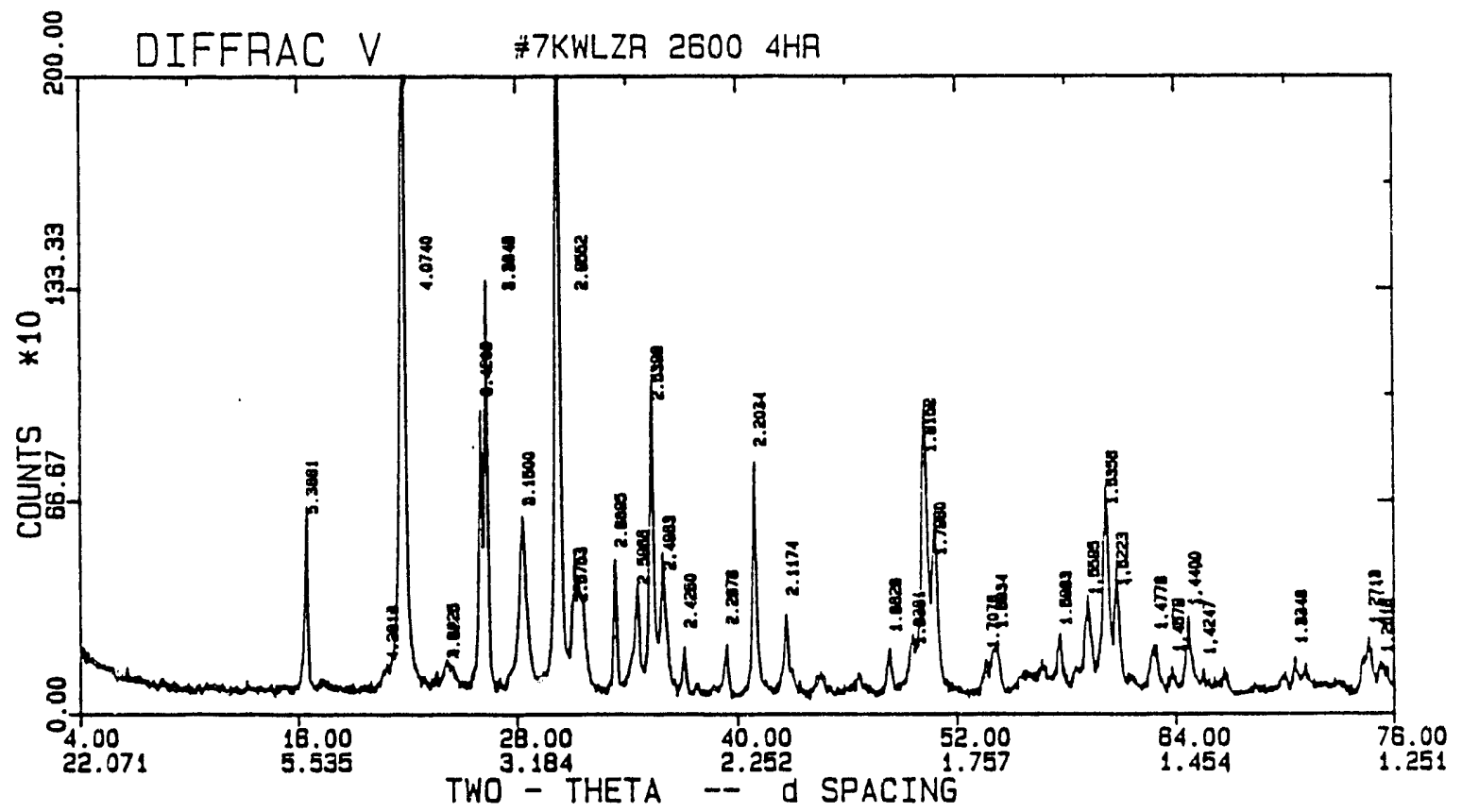

KAOWOOL ZR - AFTER 4 HOURS@2600 


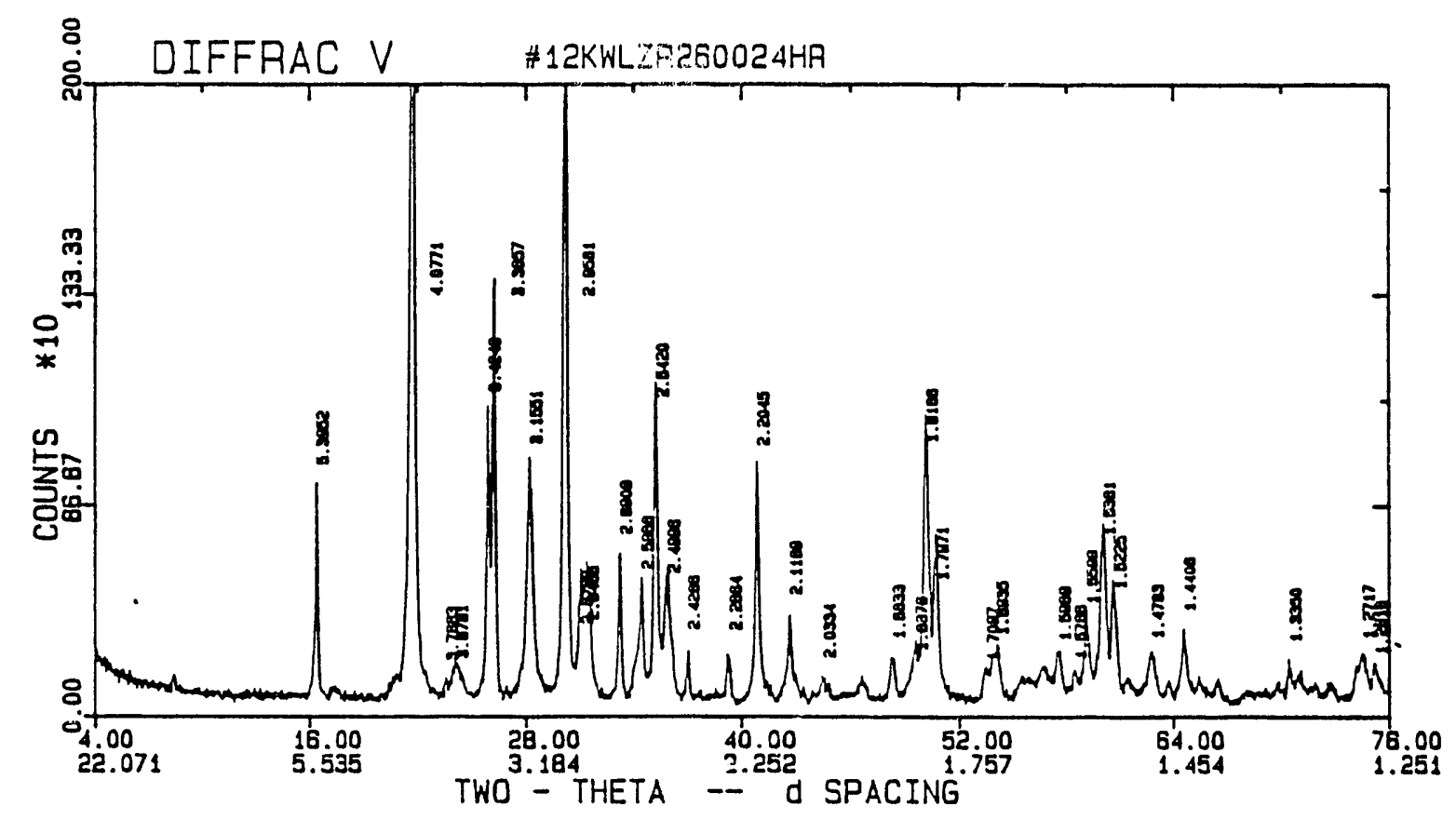

KAOWOOL ZR - AFTER 24 HOURS@ 2600 $\mathrm{F}$

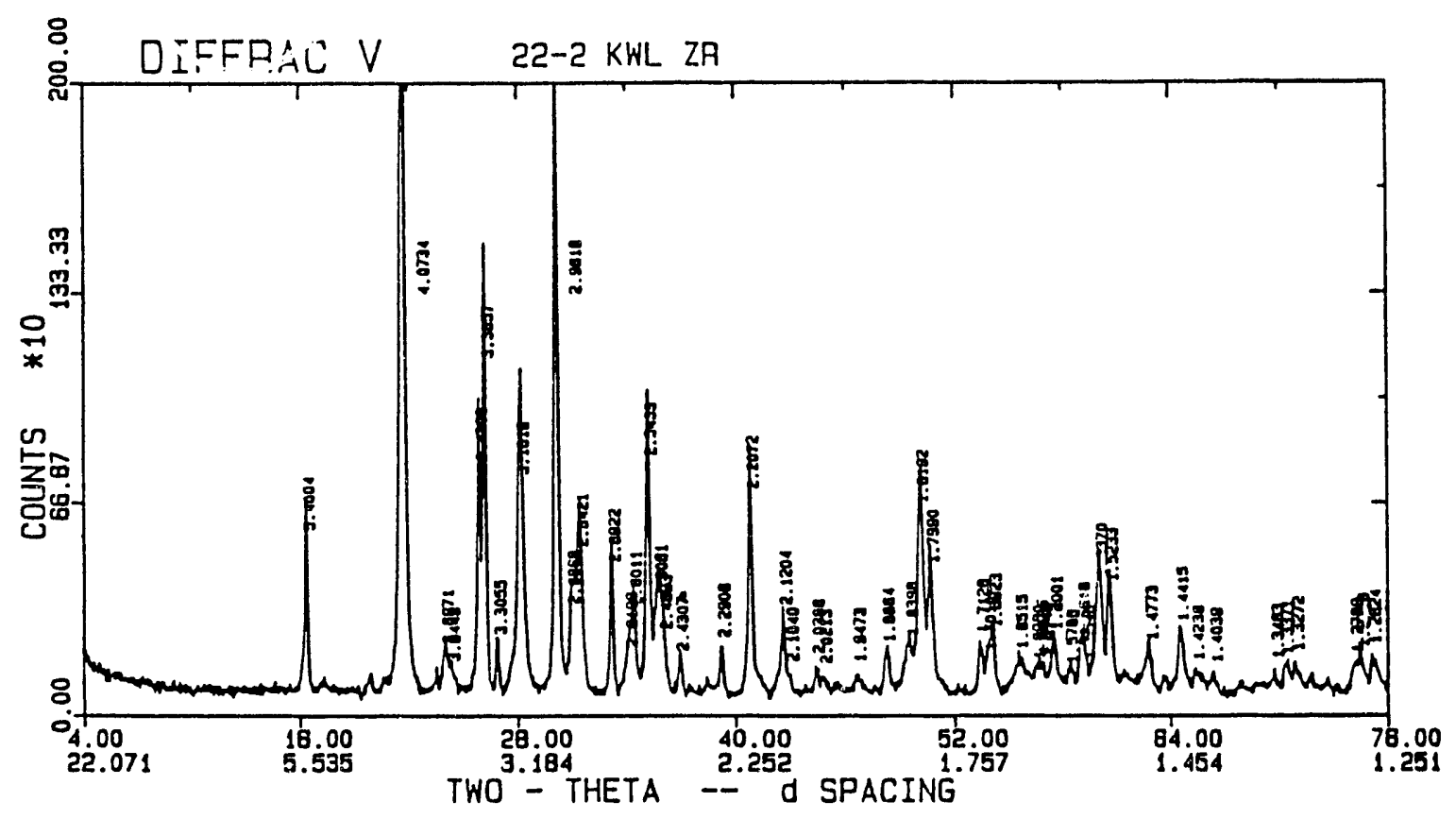

KAÔWŌOLL ZR - AFTER 168 HOURS@ $2600^{\circ} \mathrm{F}$ 


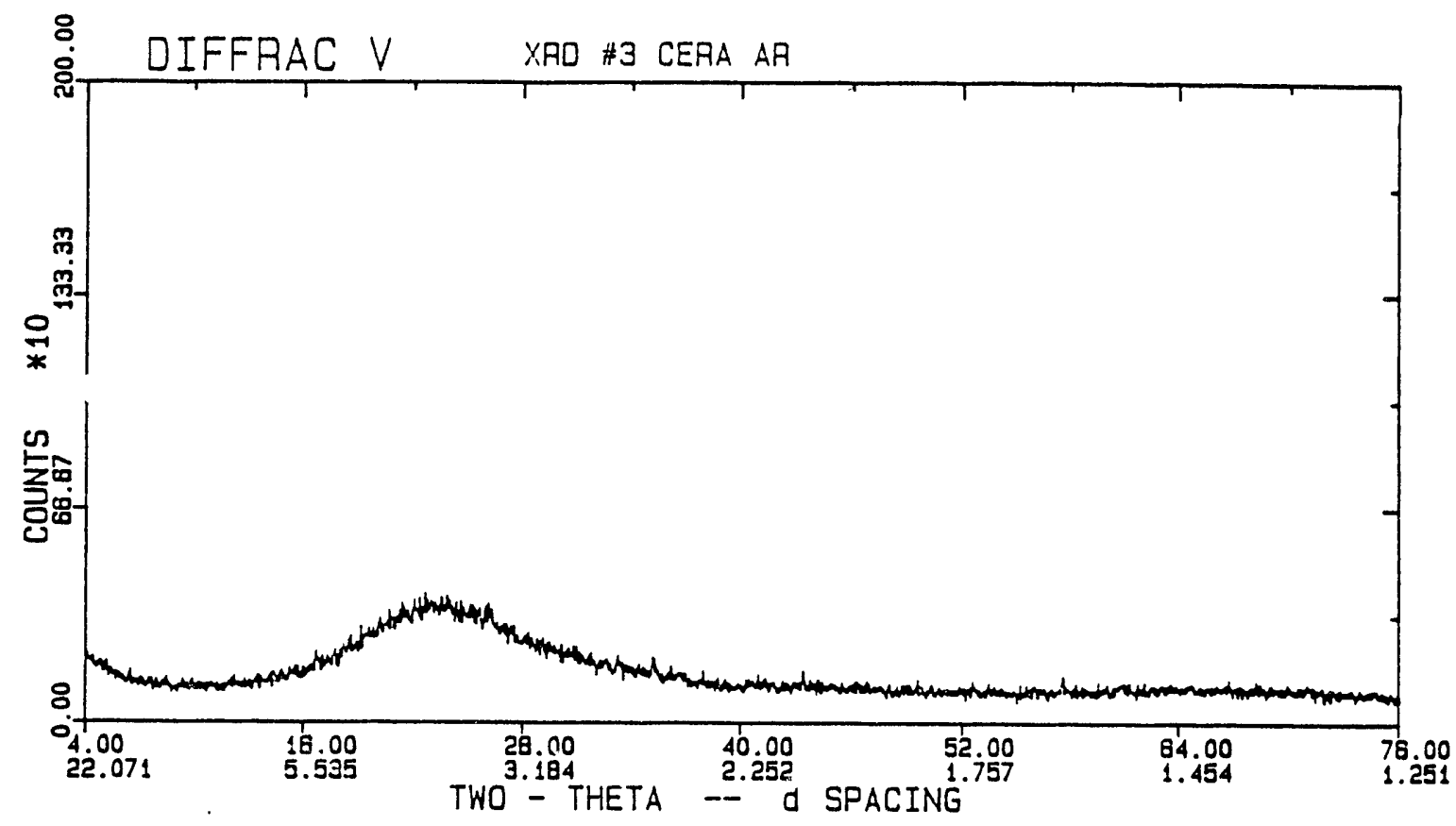

CERACHROME - AS RECEIVED

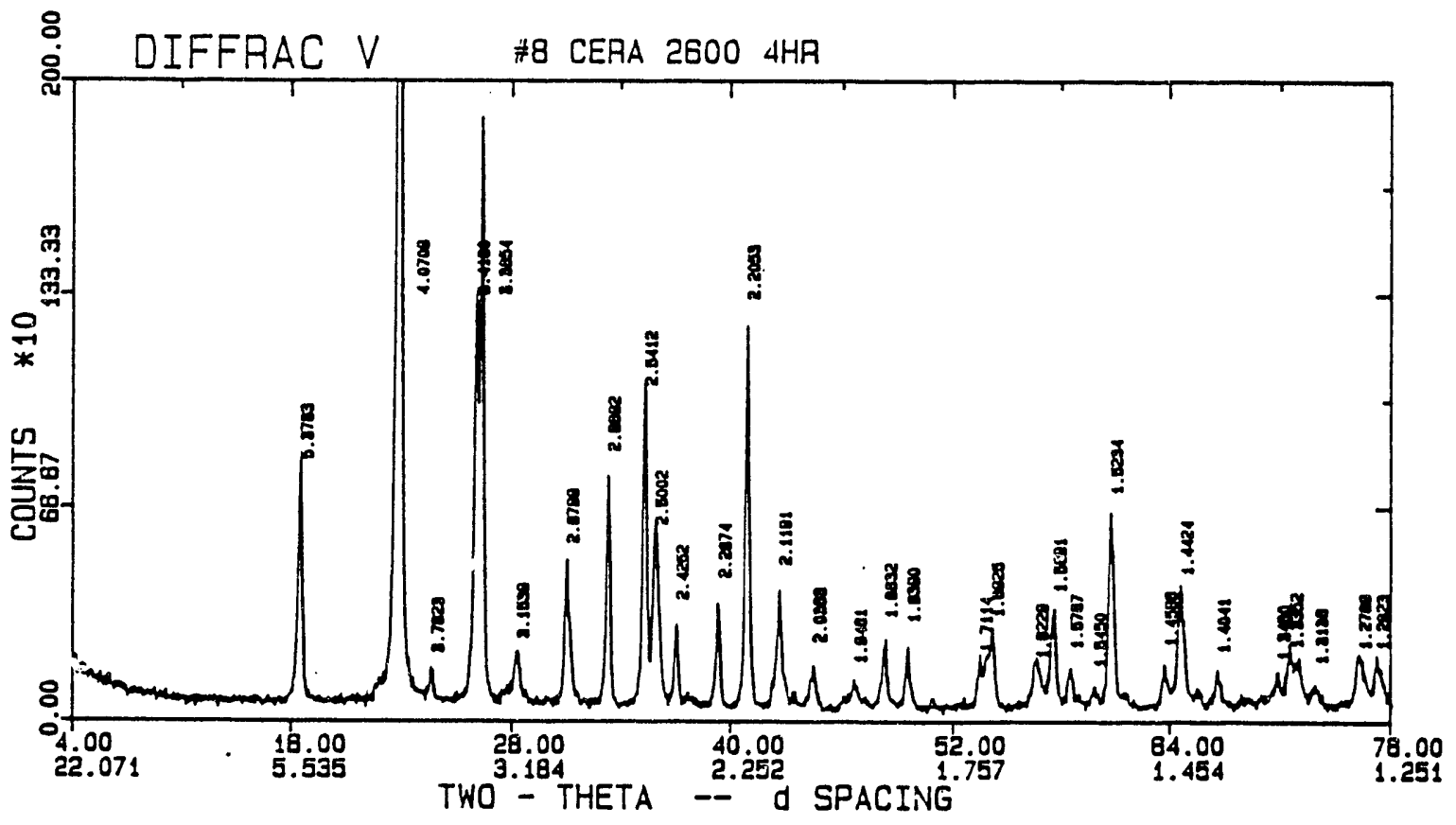

CERACHROME = AFTER 4 HOURS @ 2600

A.2.6. 


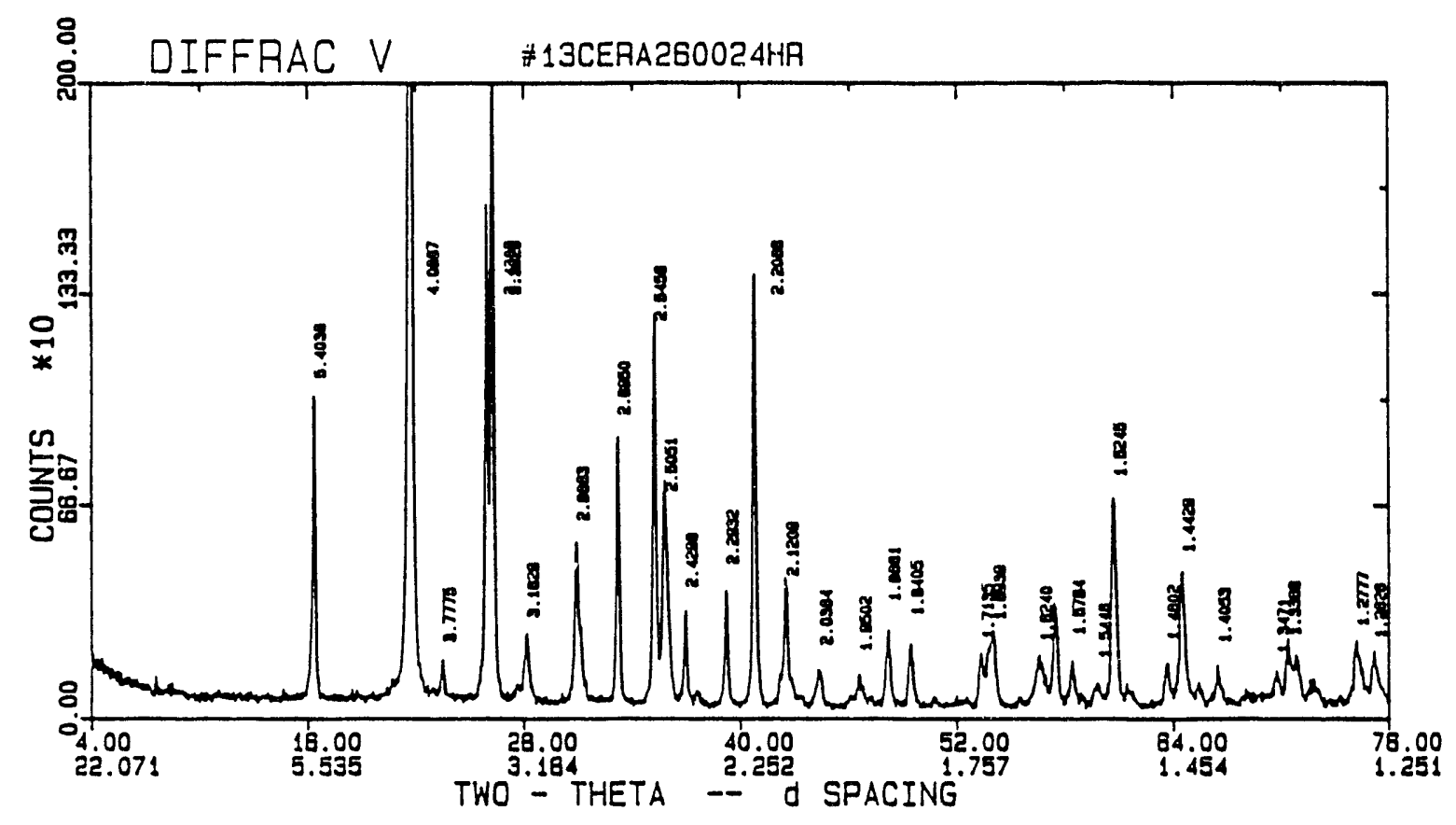

CERACHROME - AFTER 24 HOURS @ $2600^{\circ} \mathrm{F}$

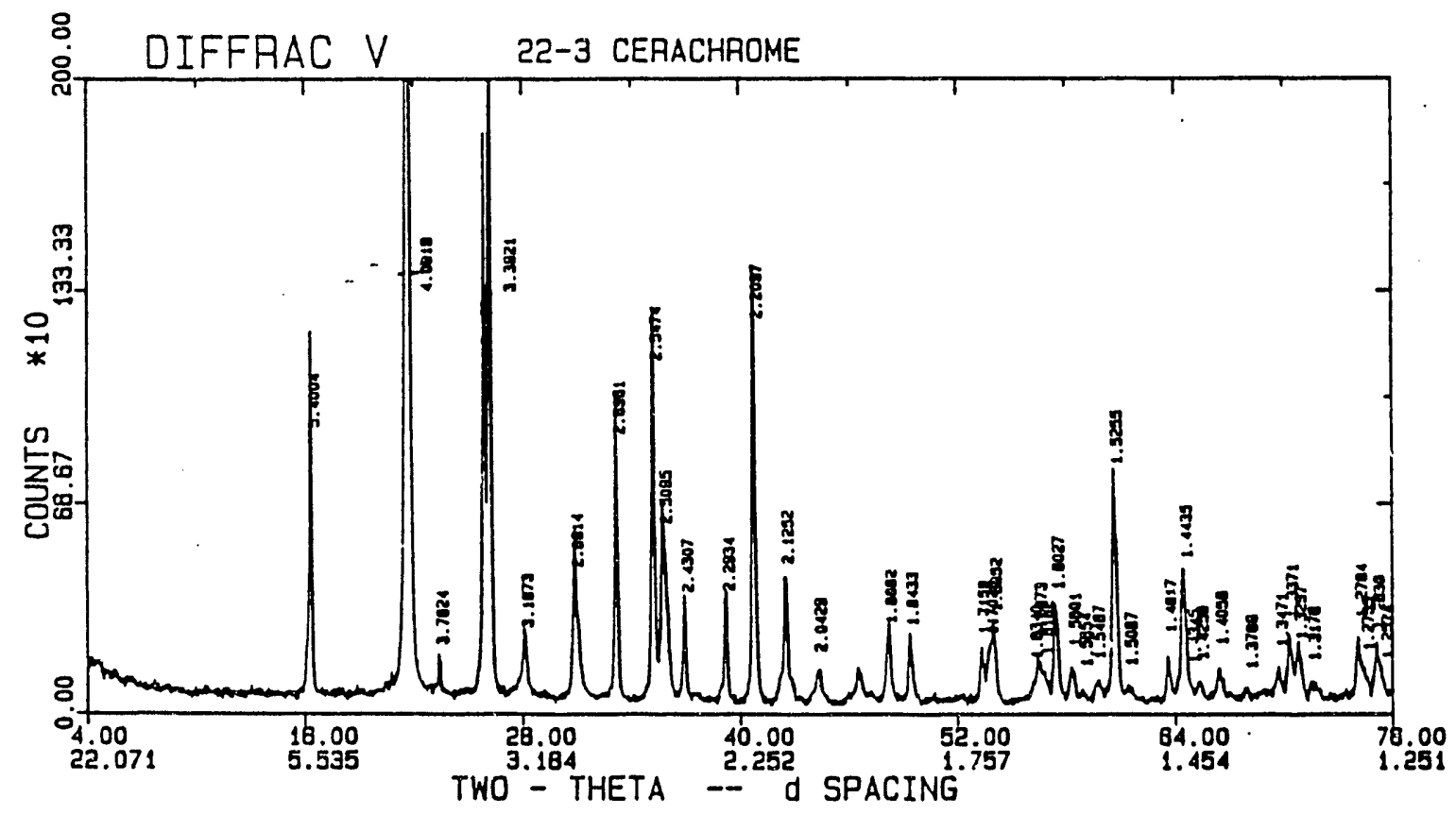

CERACHROME - AFTER 168 HOURS@2600 F 


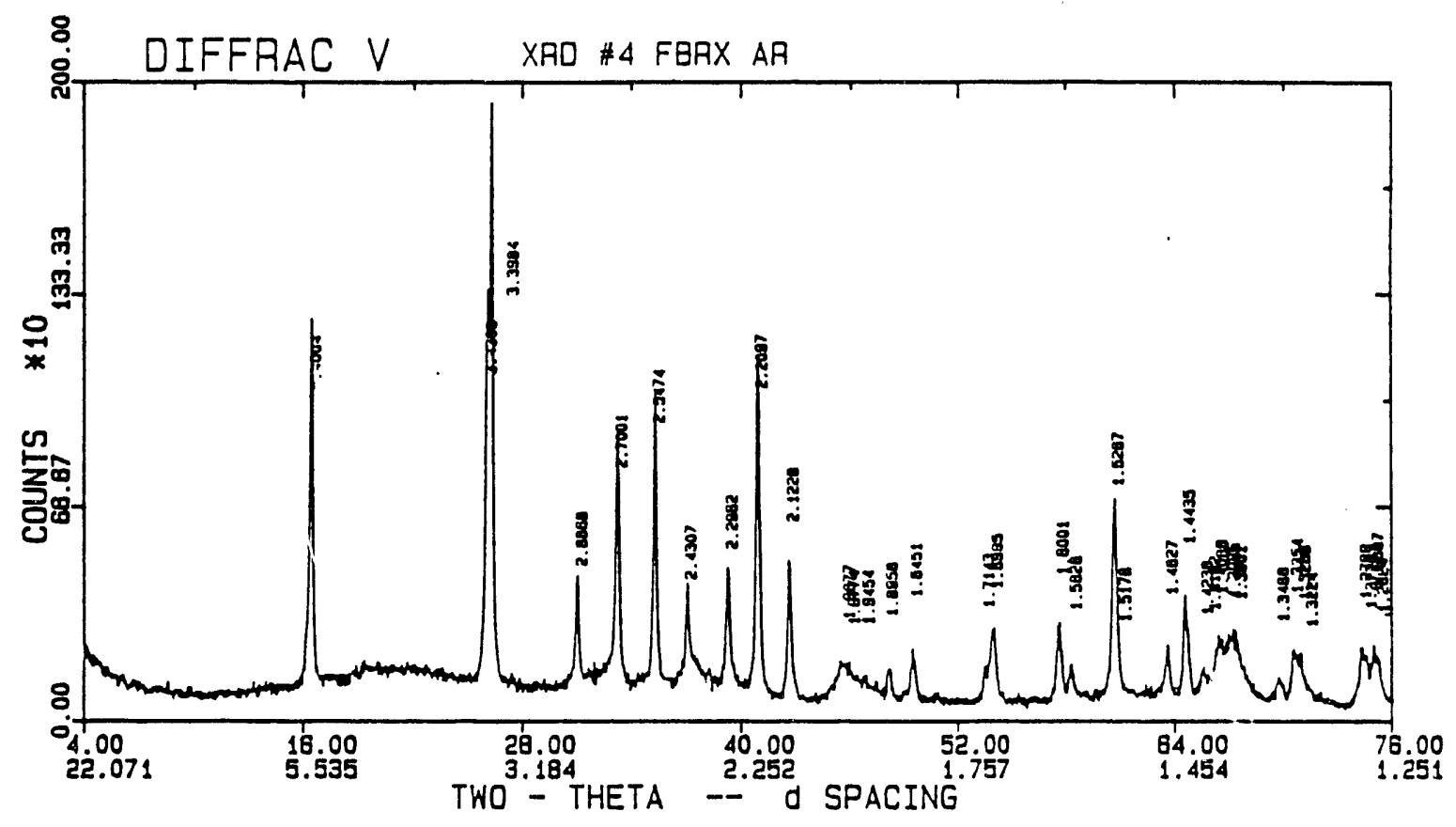

FIBERMAX - AS RECEIVED

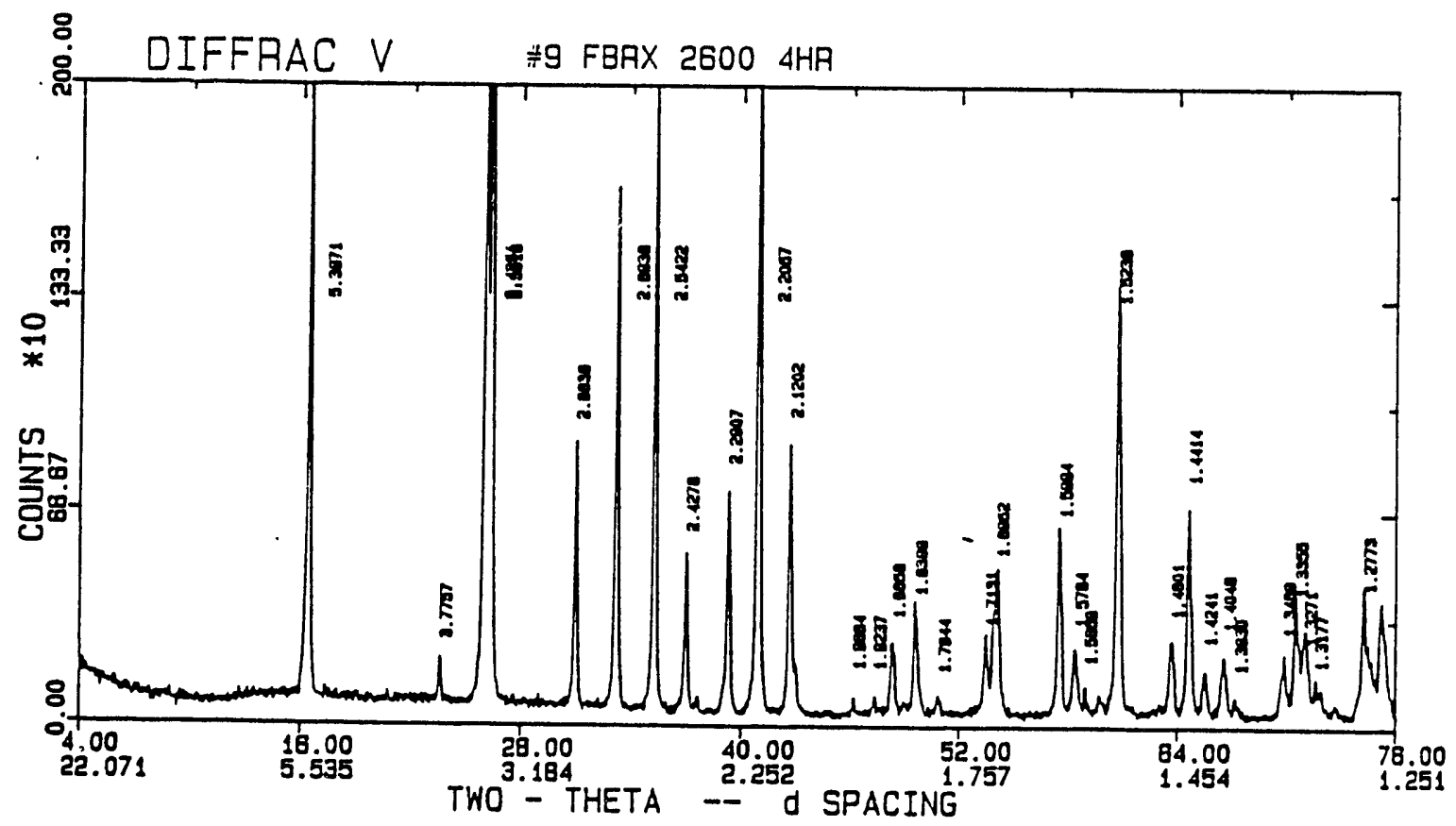

FIBERMÃX - ÁFTEK 4 HOUUTS@ 26000 


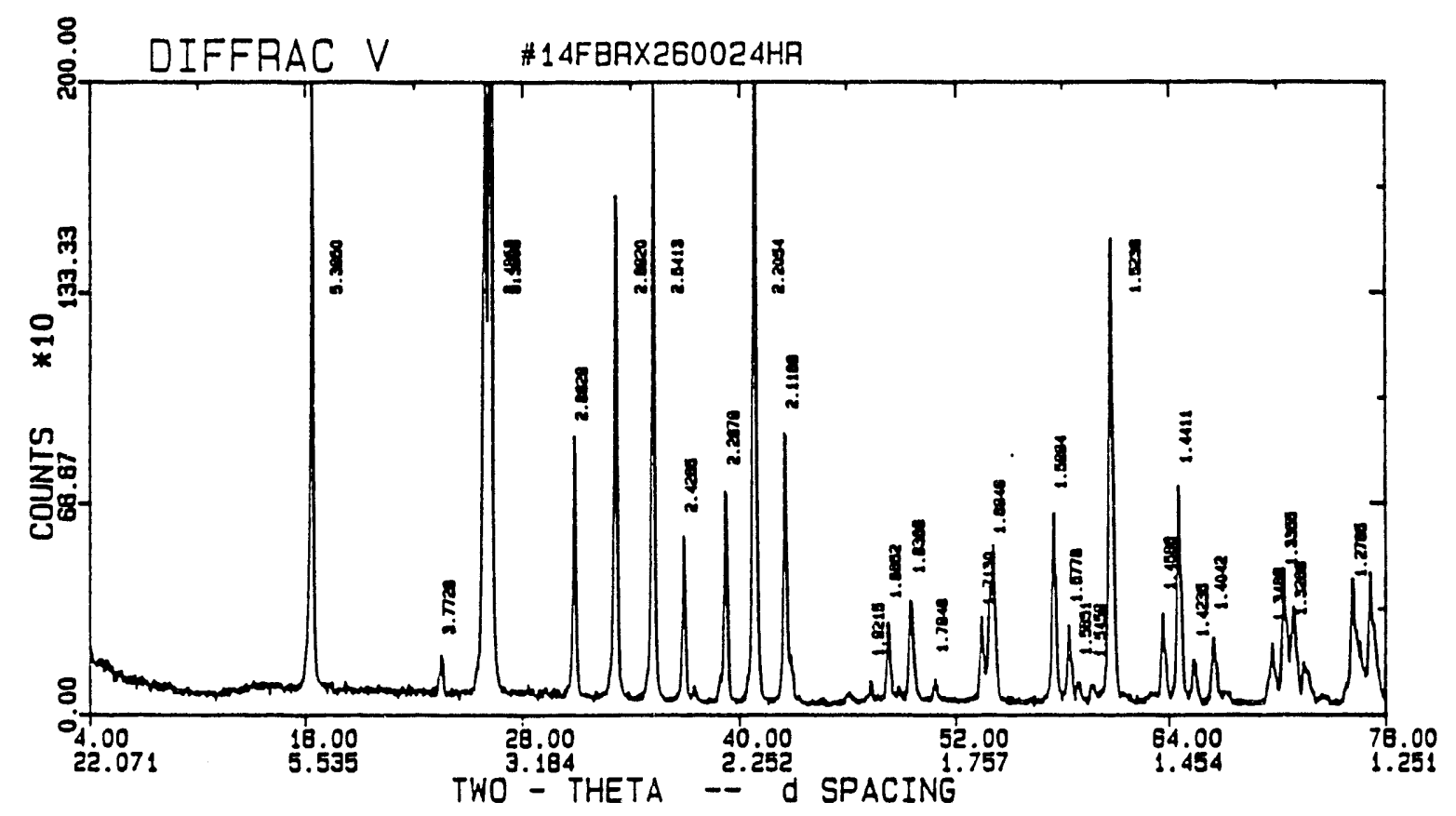

FIBERMAX - AFTER 24 HOURS @ 2600 $\mathrm{F}$

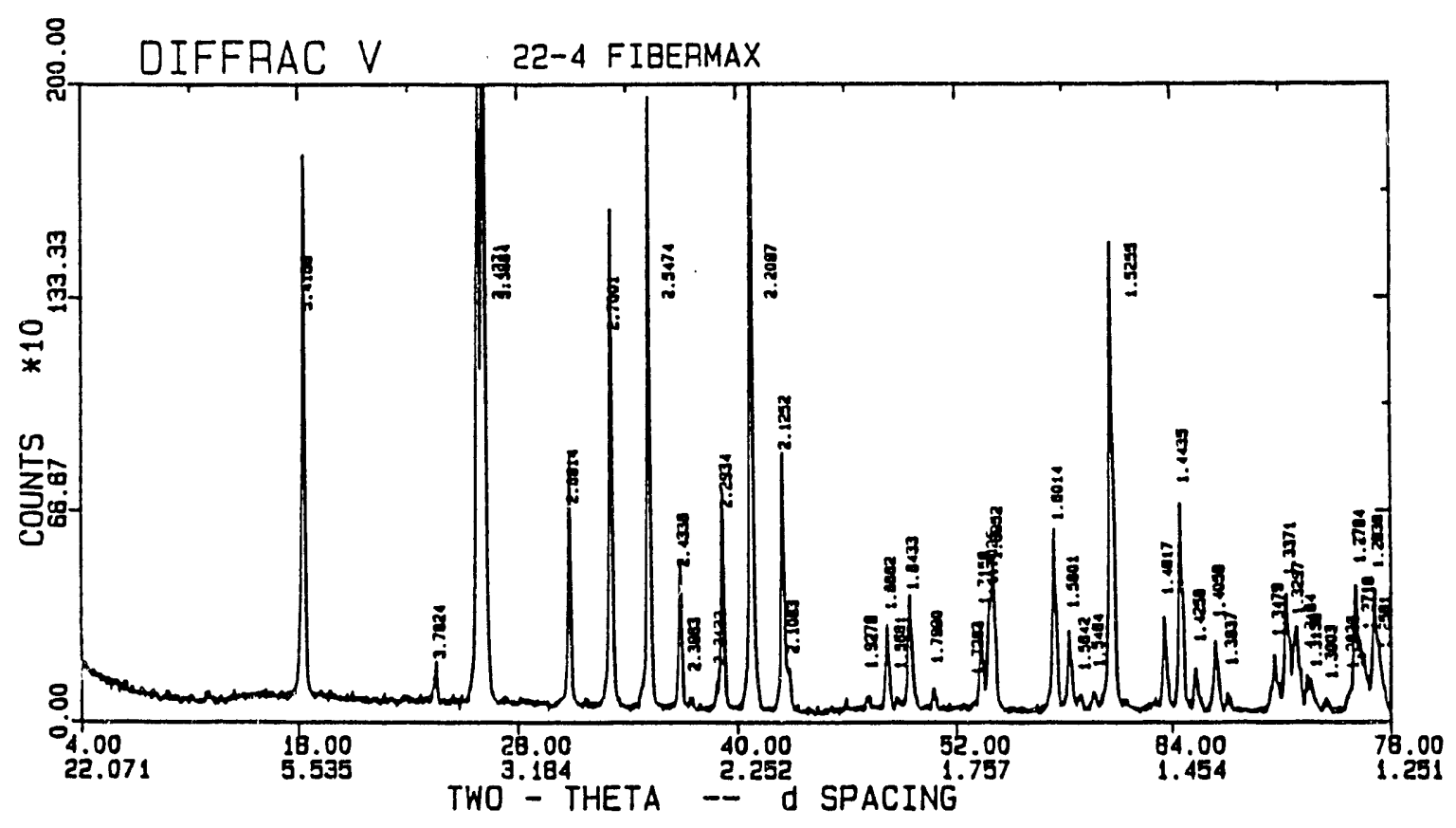

FIBERMAX - AFTER 168 HOURS @ 2600' F 


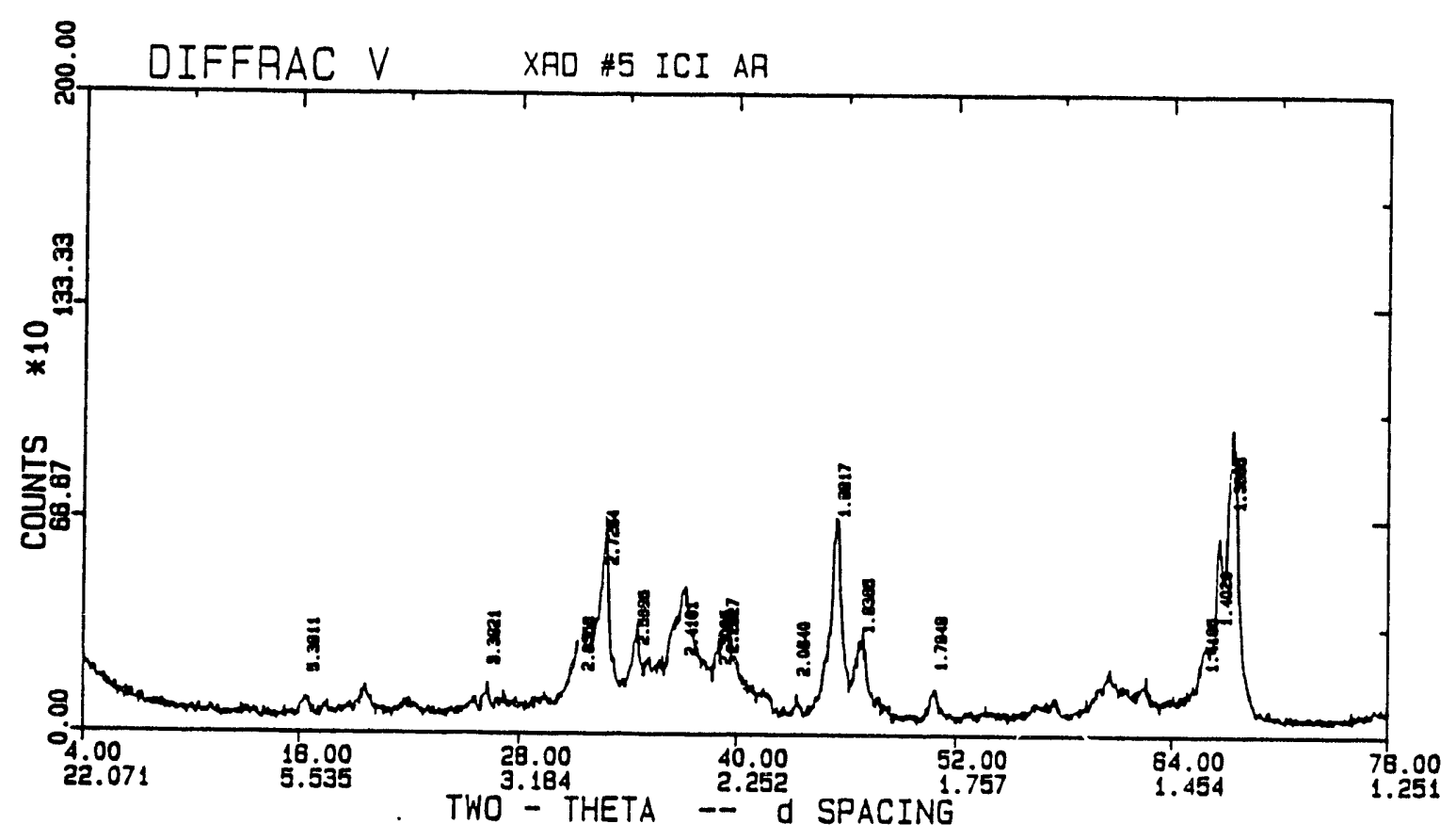

\section{SAFFIL - AS RECEIVED}

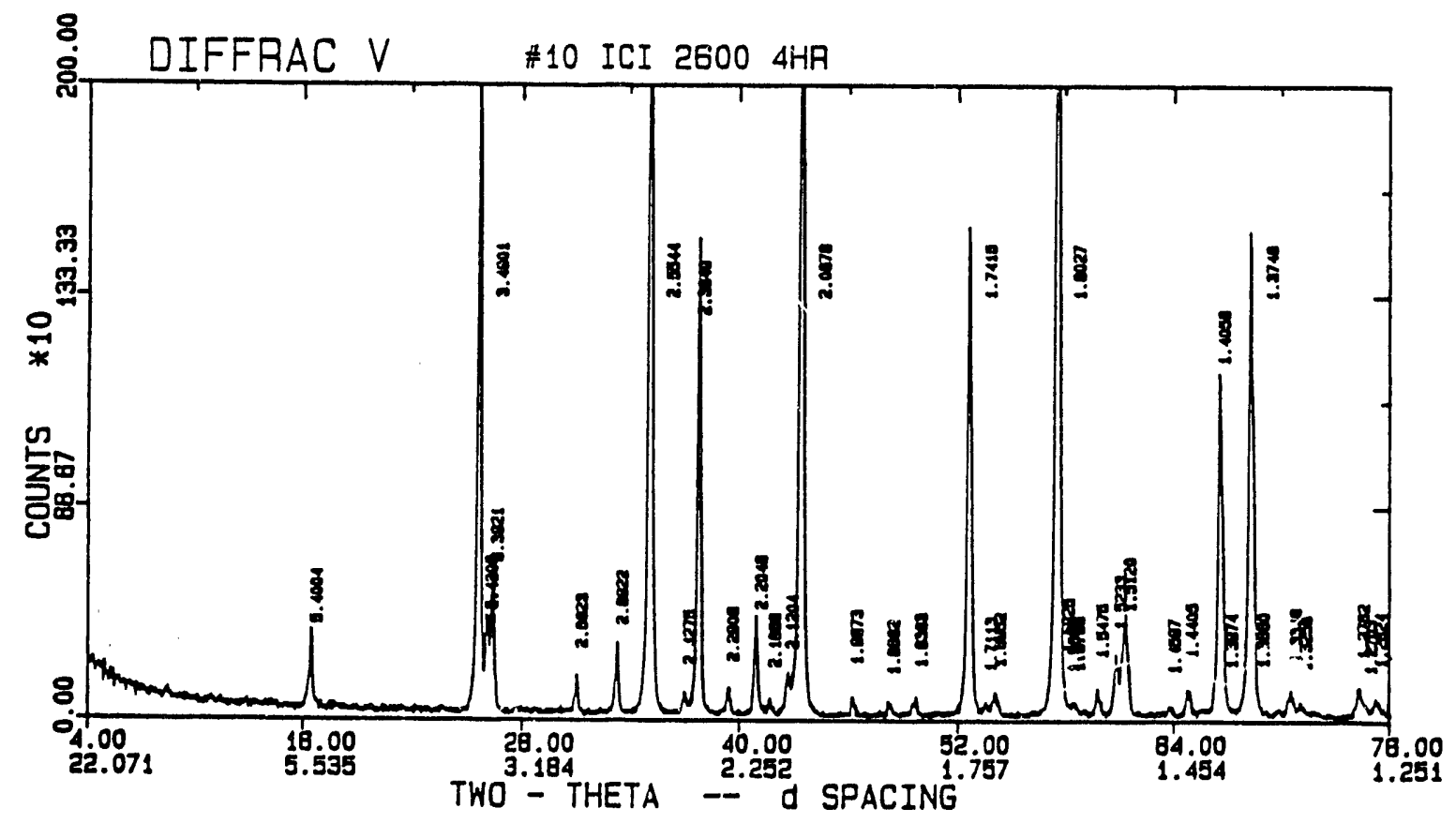

SAFFiL - AFTER4 HOURS @ 20́00F 

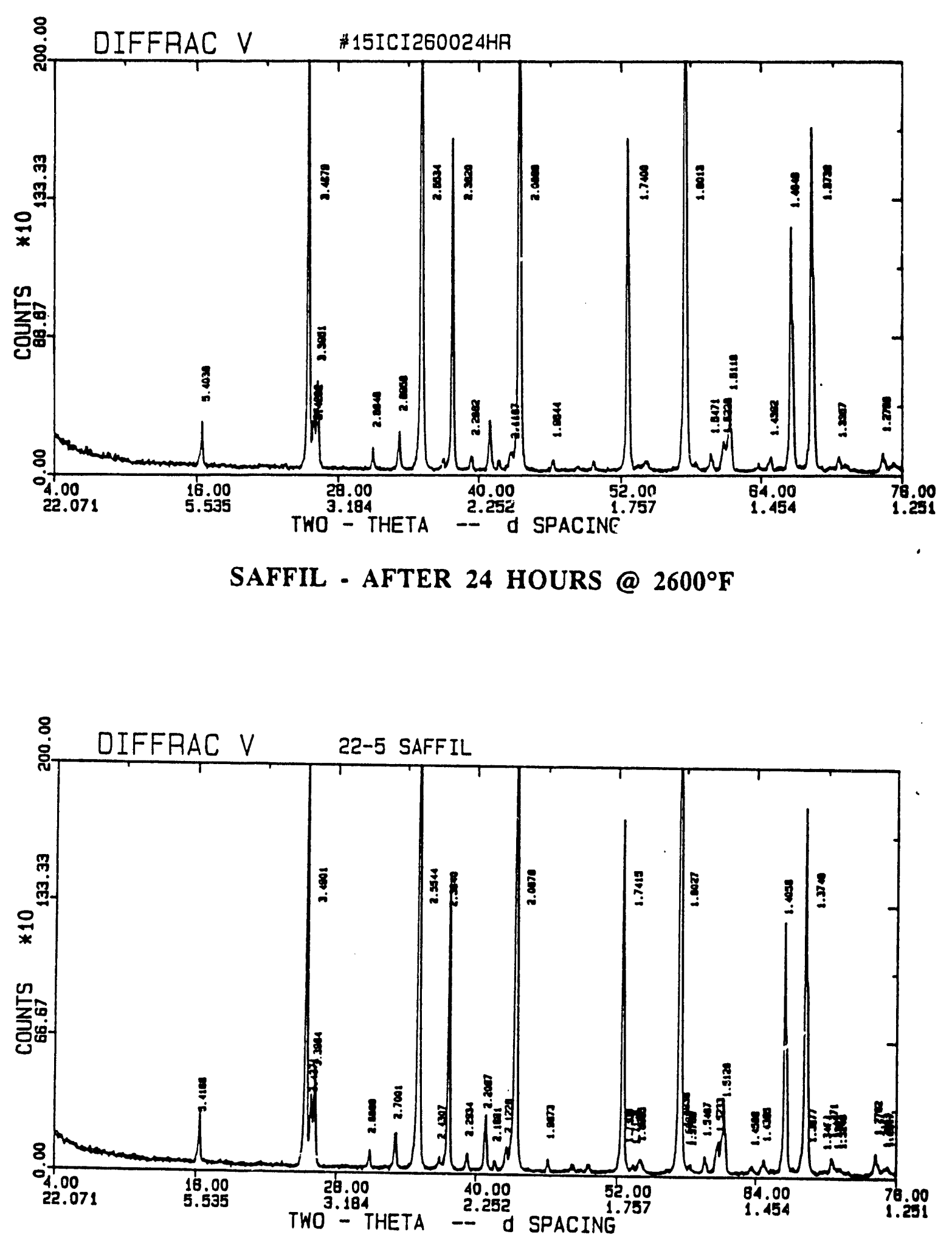

SAFFIL - AFTER 168 HOURS@ $2600^{\circ} \mathrm{F}$ 


\title{
PPENDIX A.3
}

SEM VIEWS AFTER HEAT TREATMENT AT $2600^{\circ} \mathrm{F}$

\author{
A.3.1
}



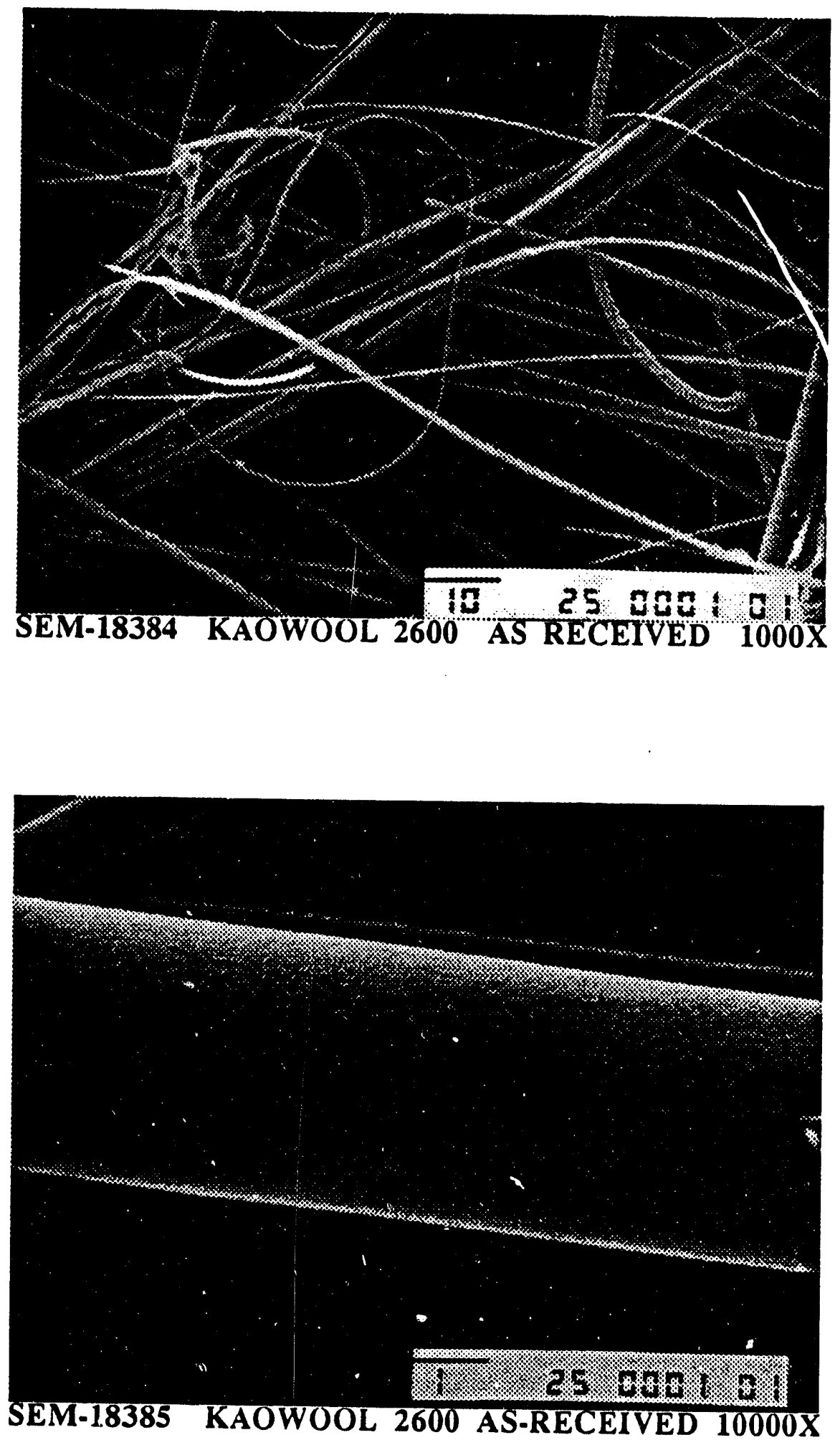

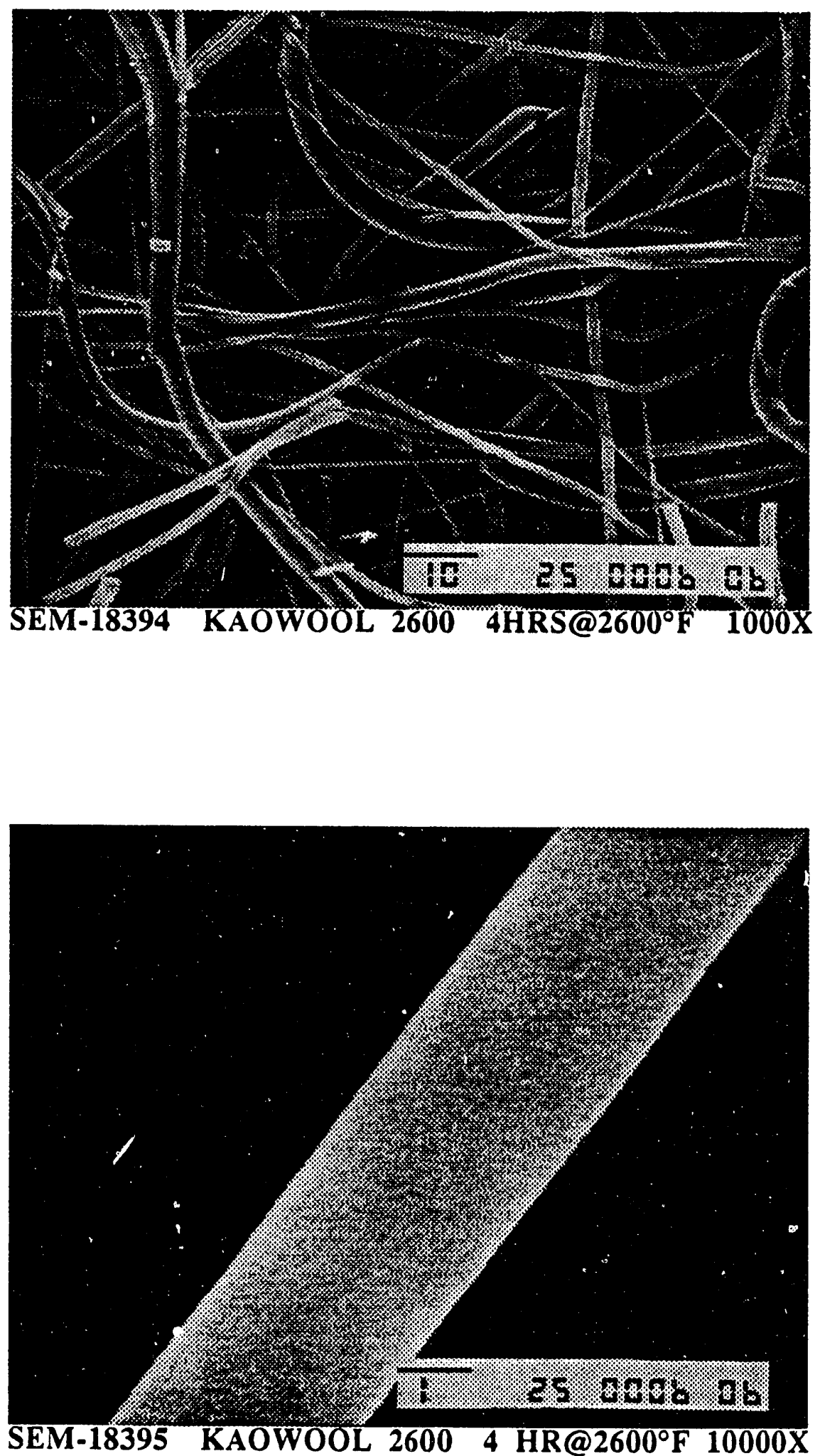

A.3.3 

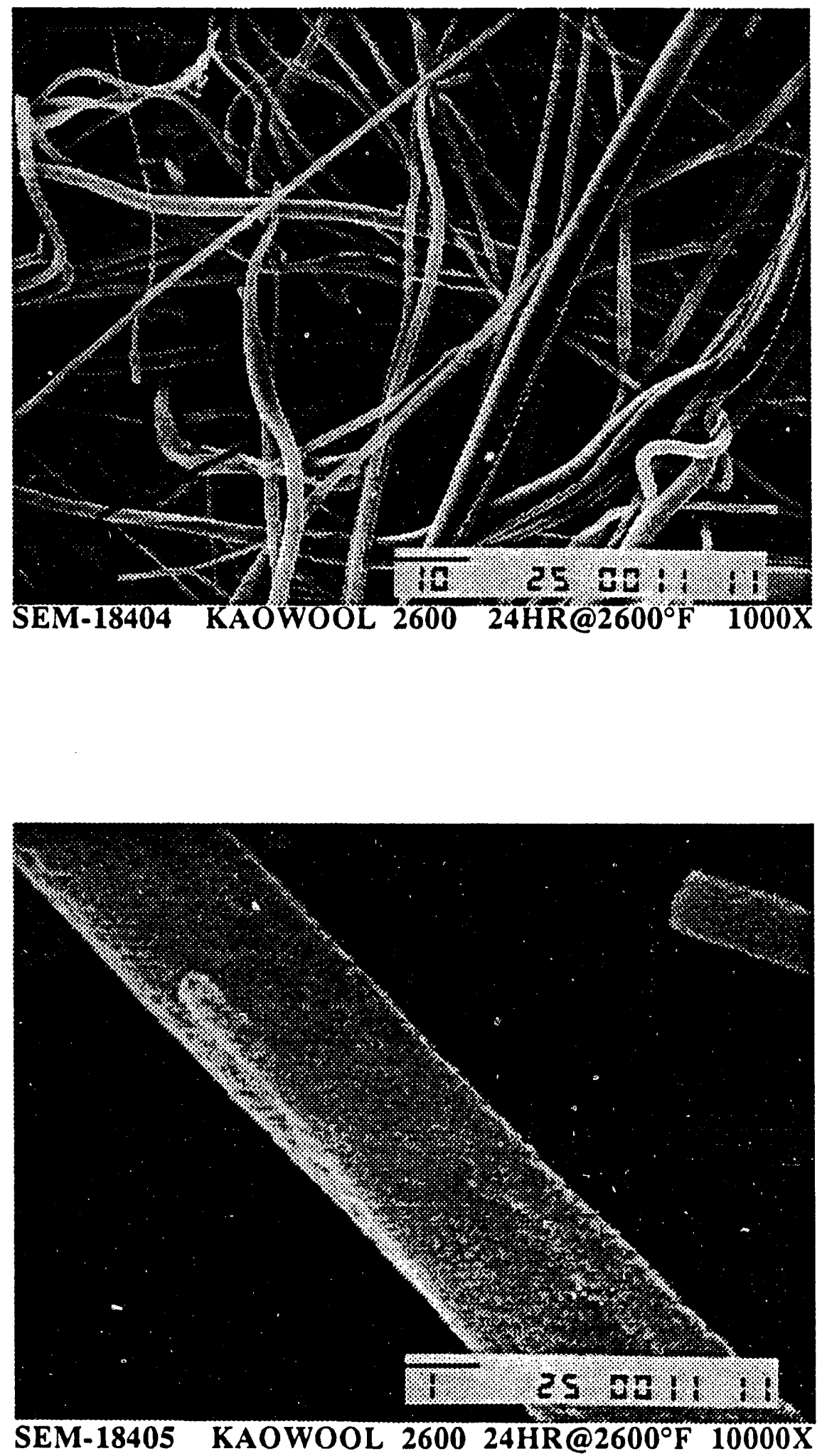

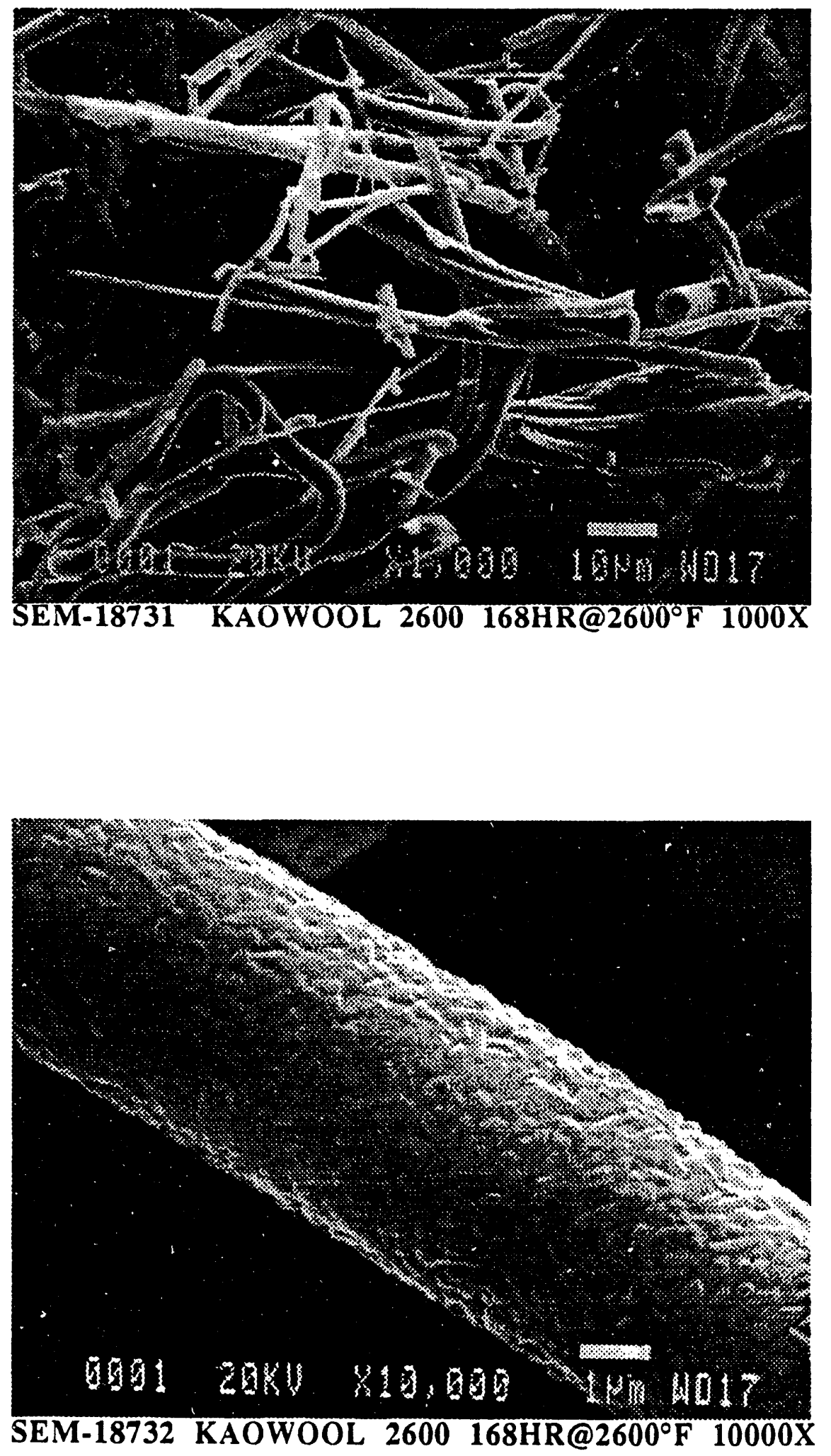

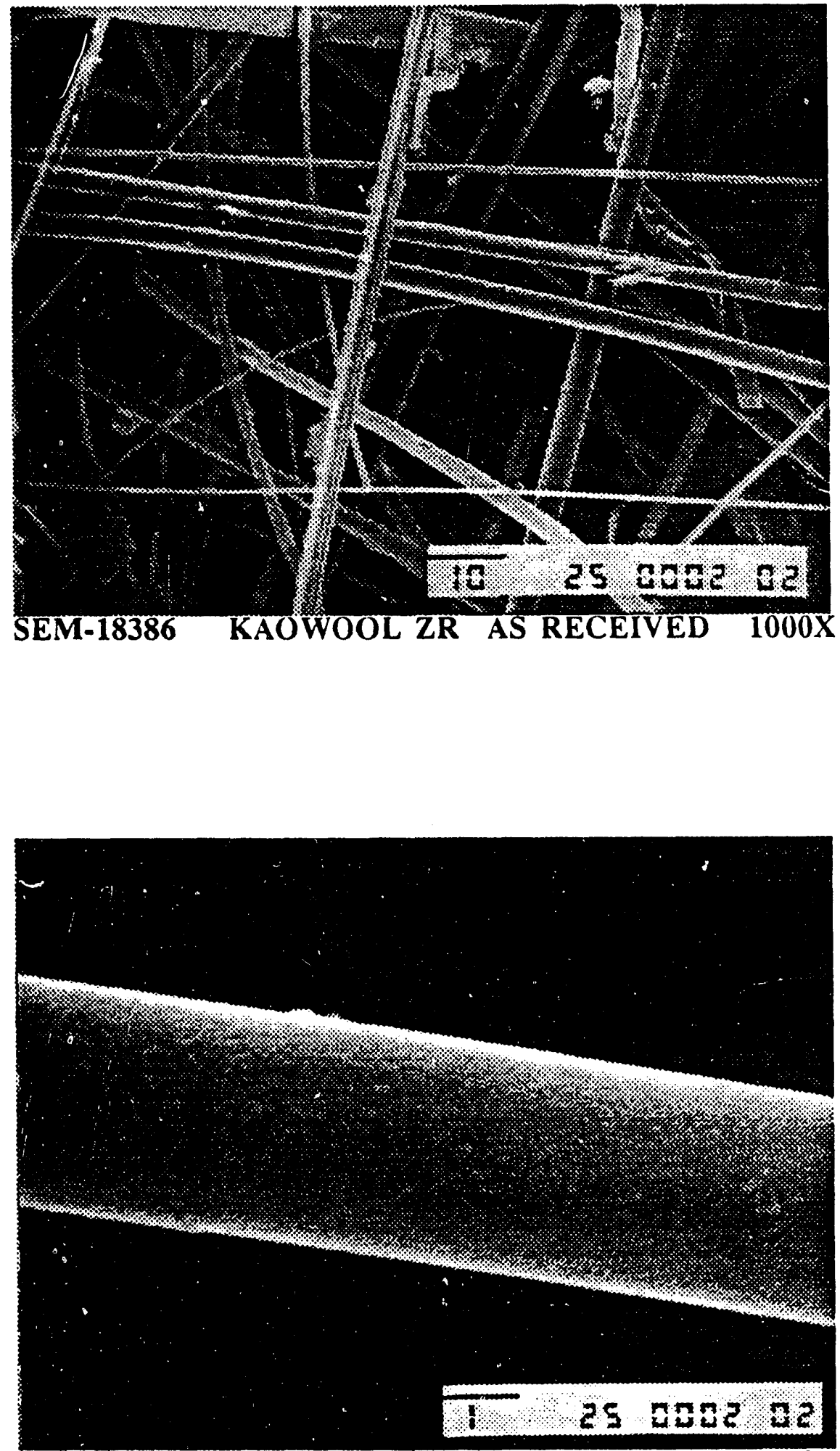

SEM-18387 KAOWOOL ZR AS RECEIVED 10000X 

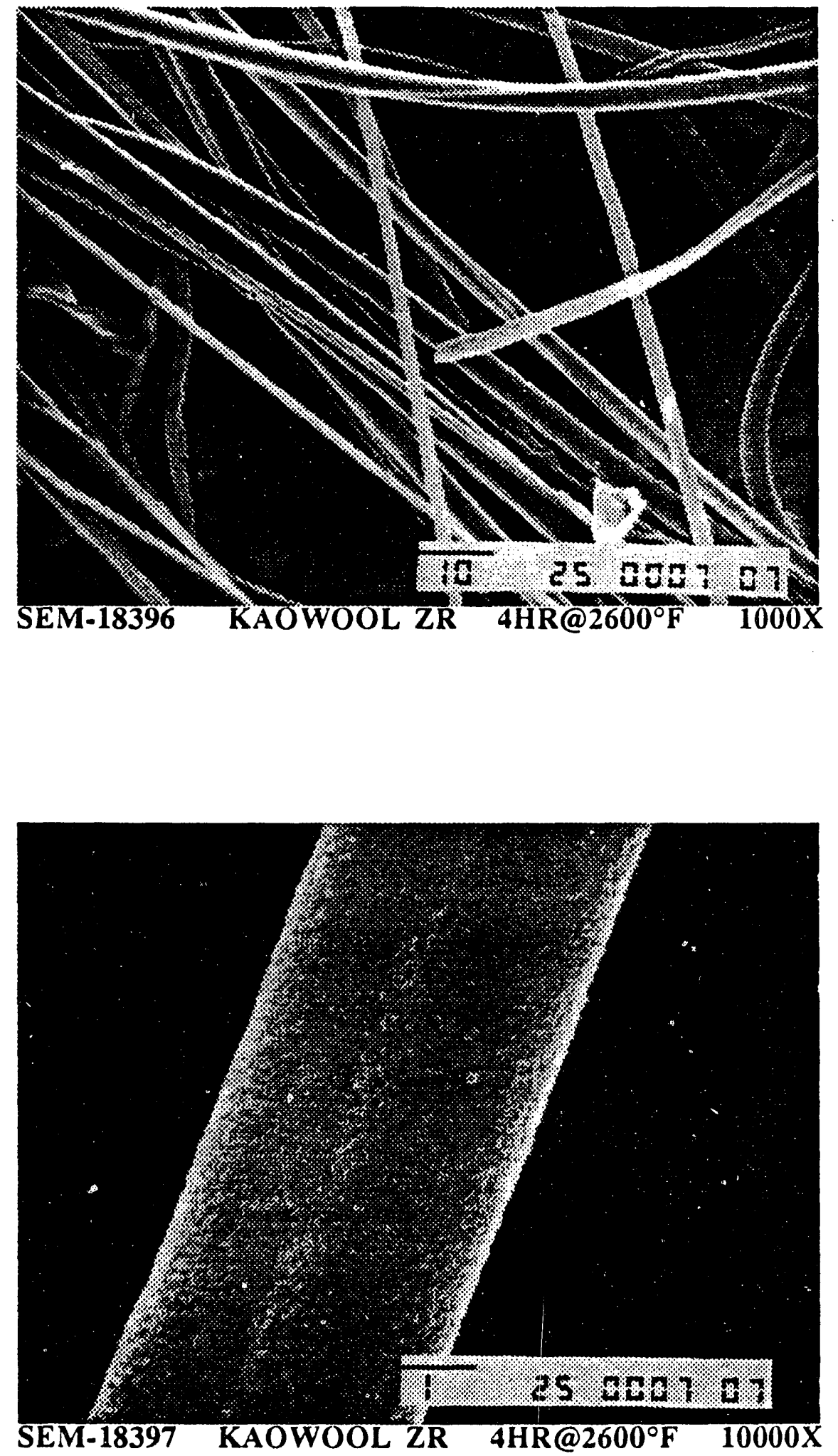

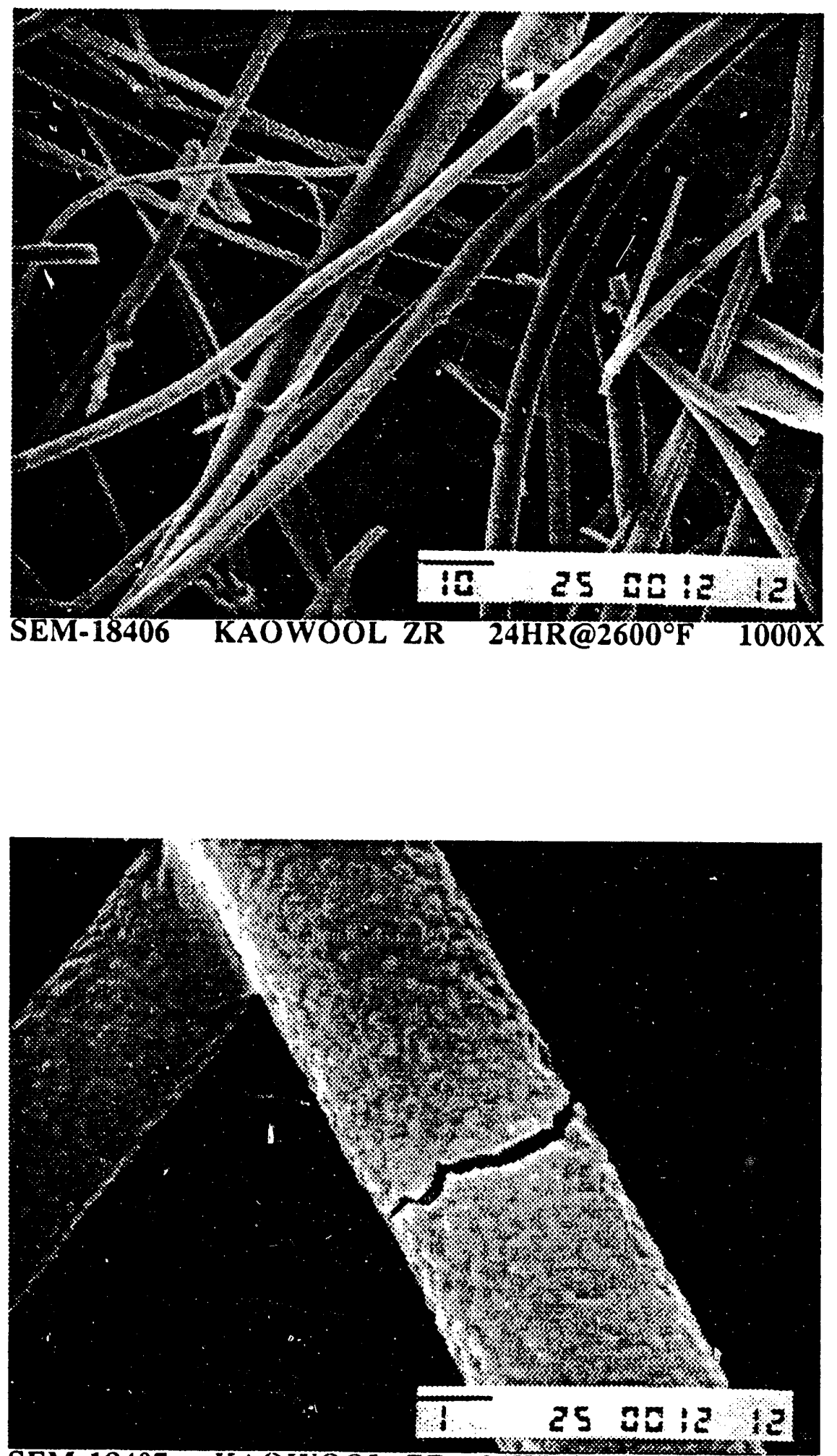

SEM-18407 KAOWOOL ZR 24HR@2600 

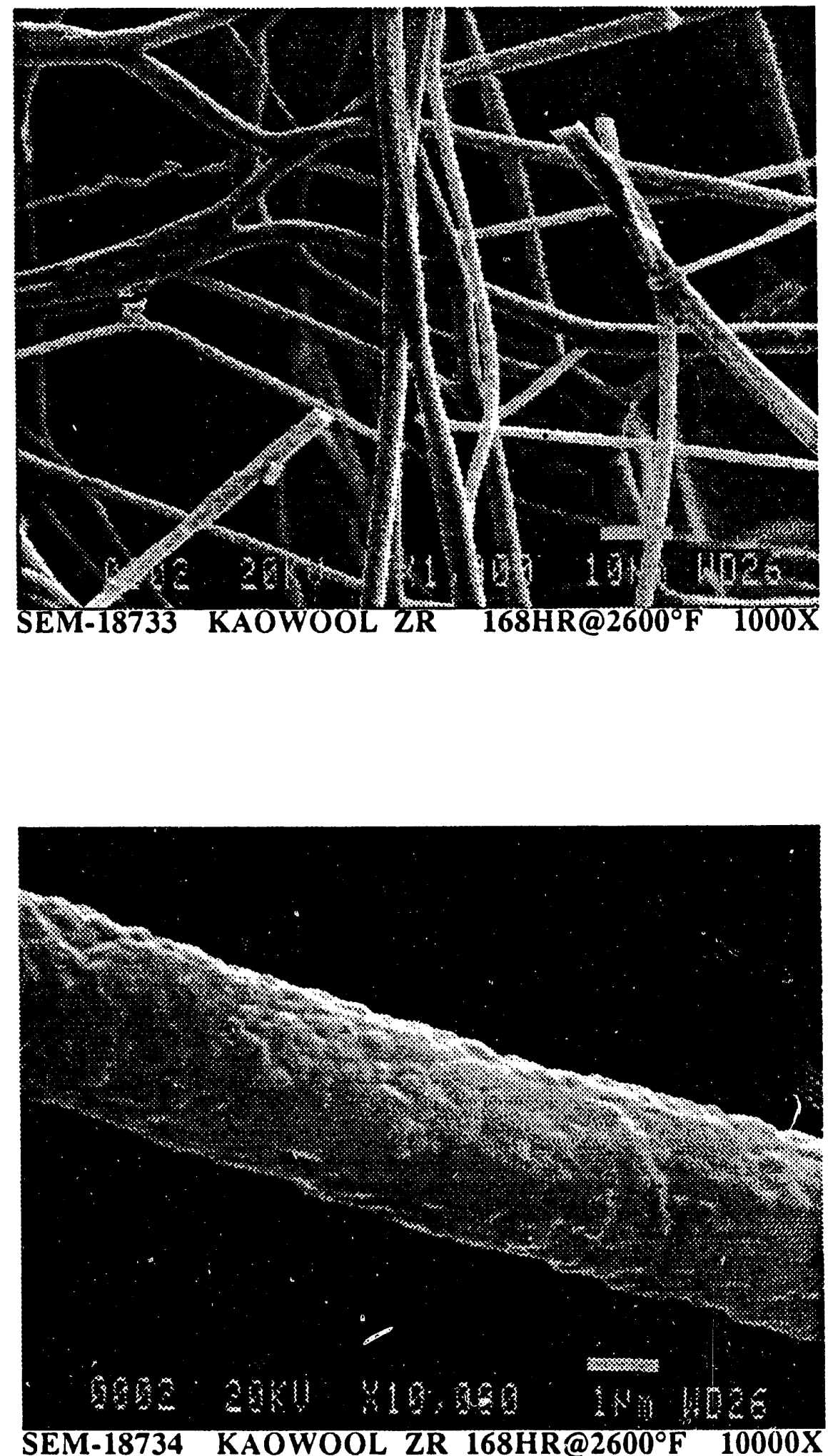

A. 3.9 

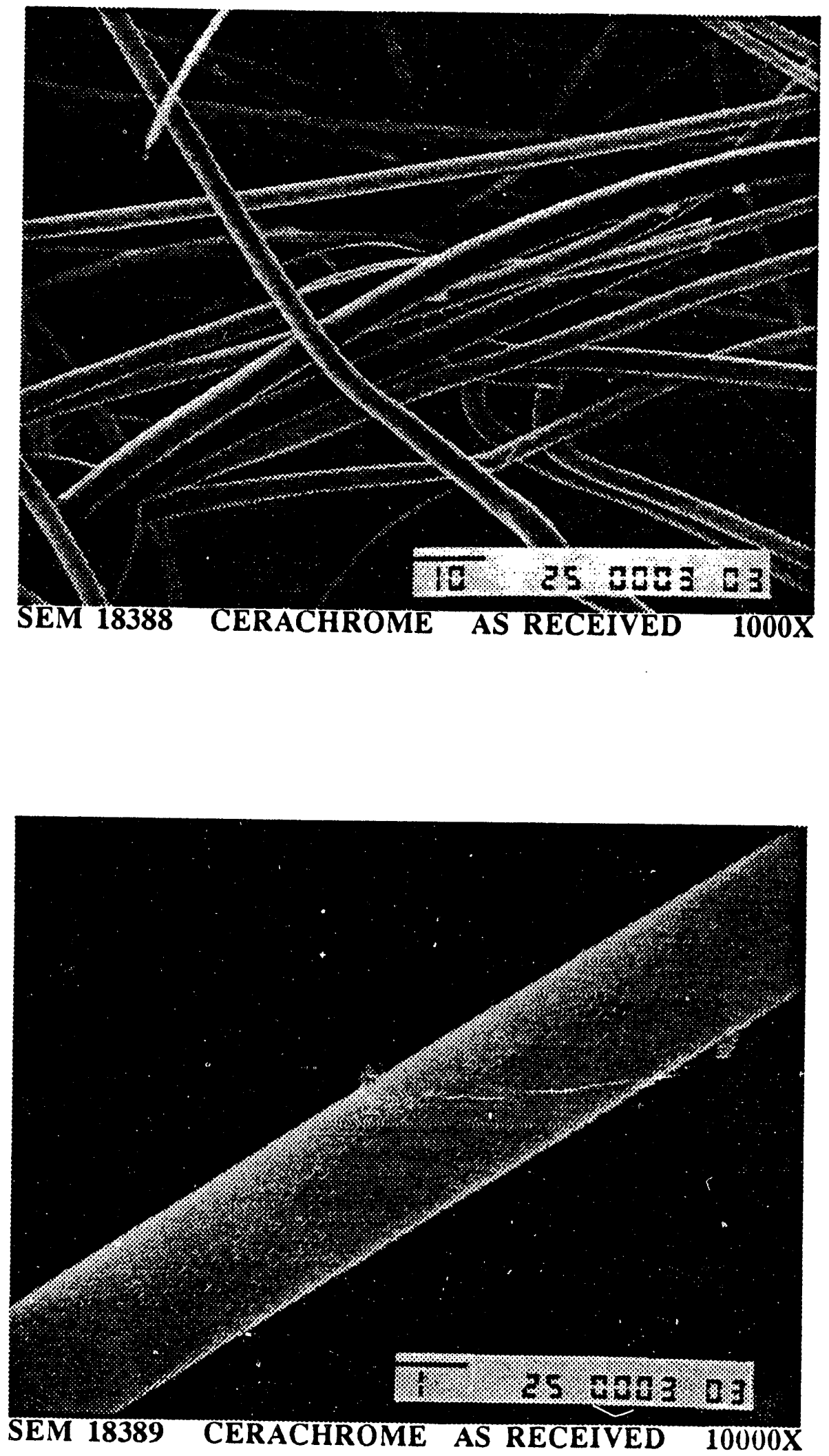

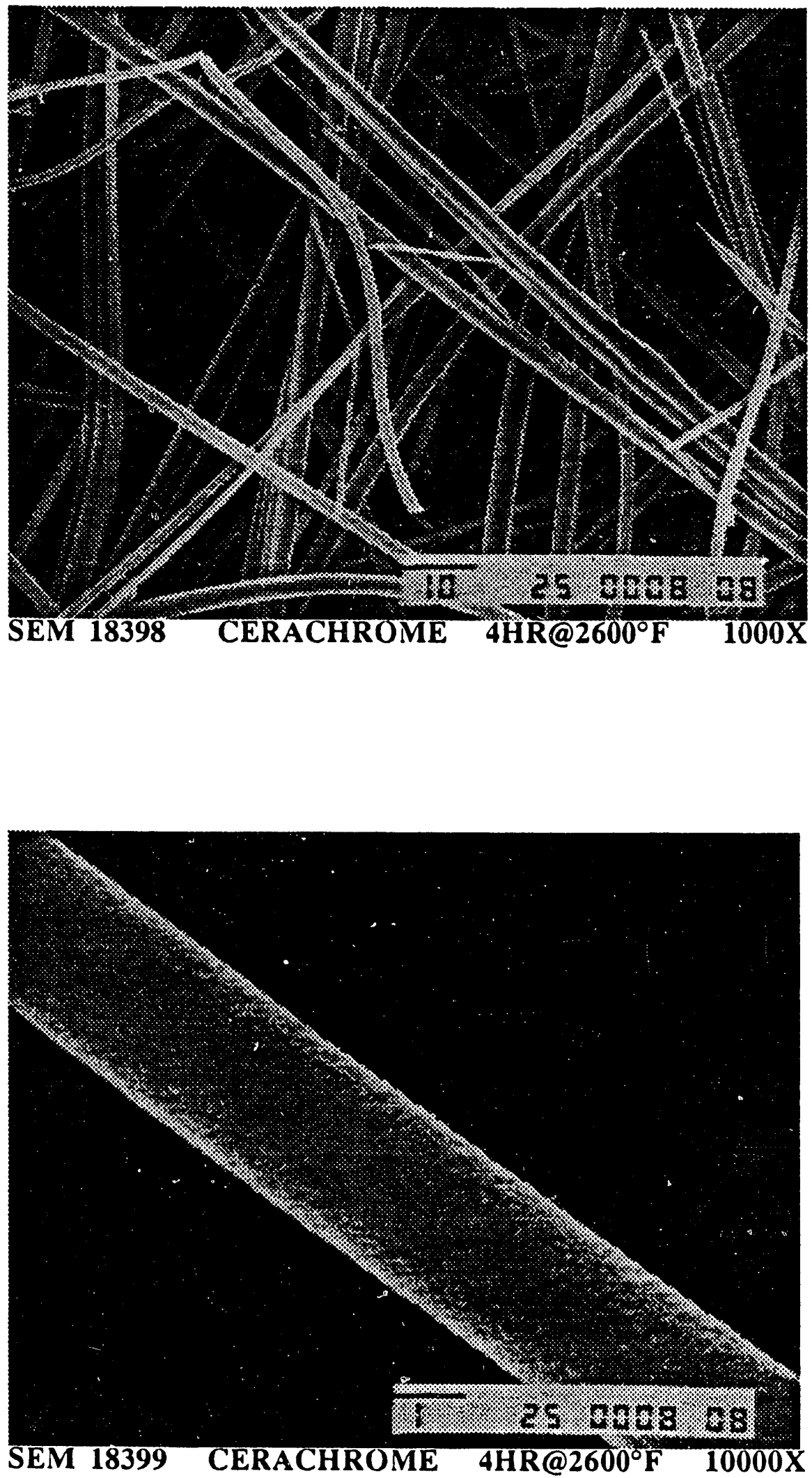

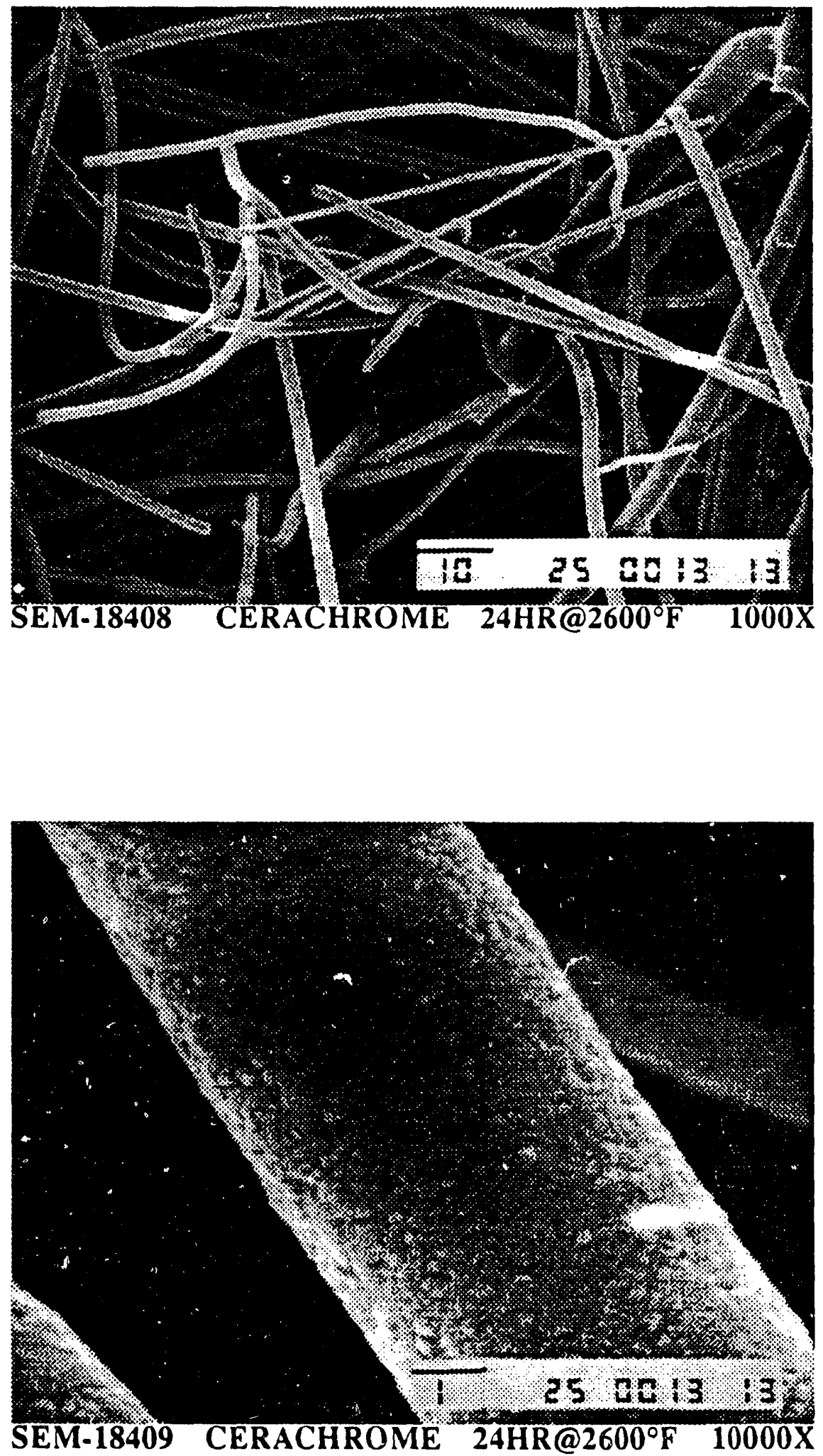

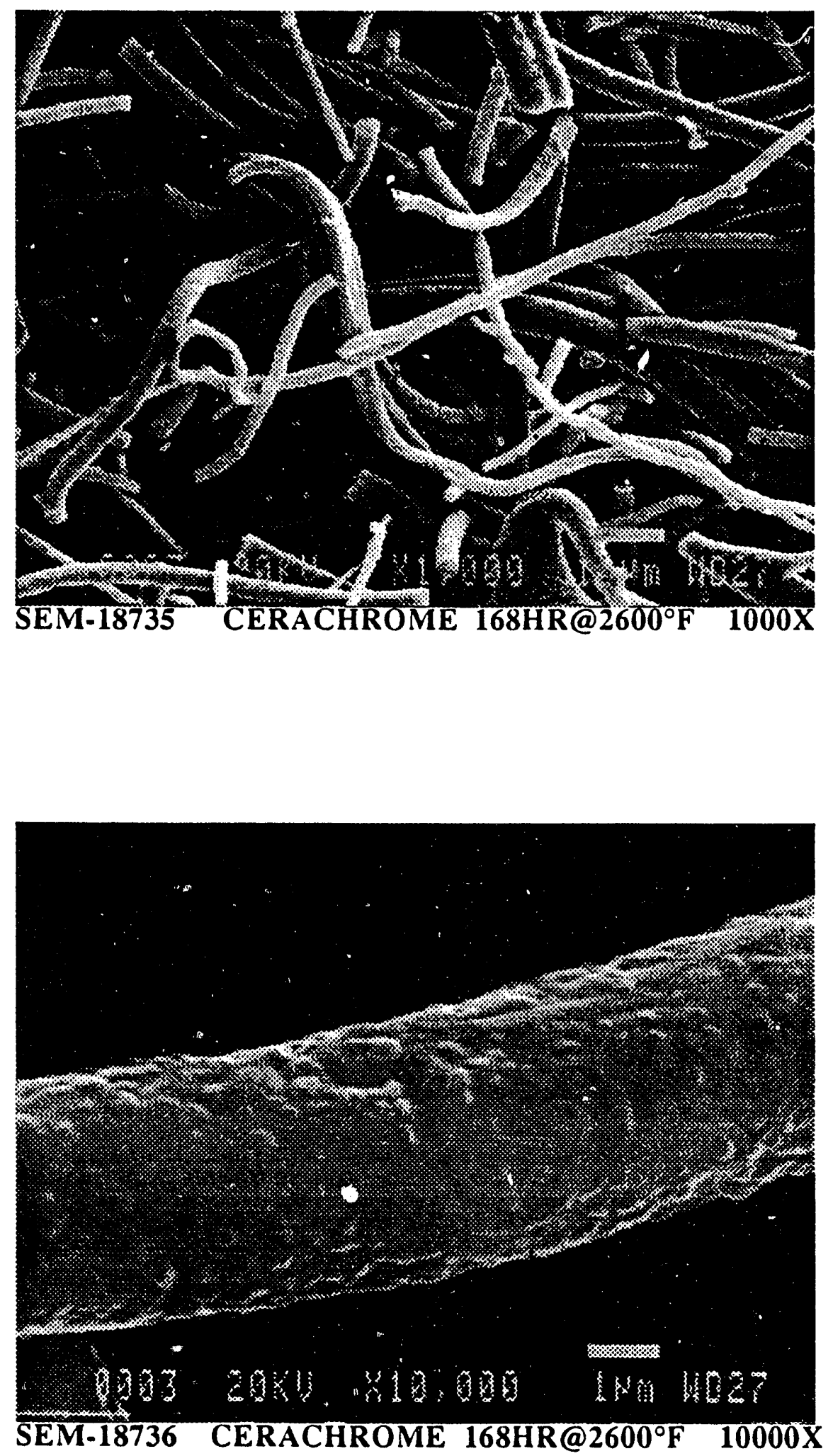

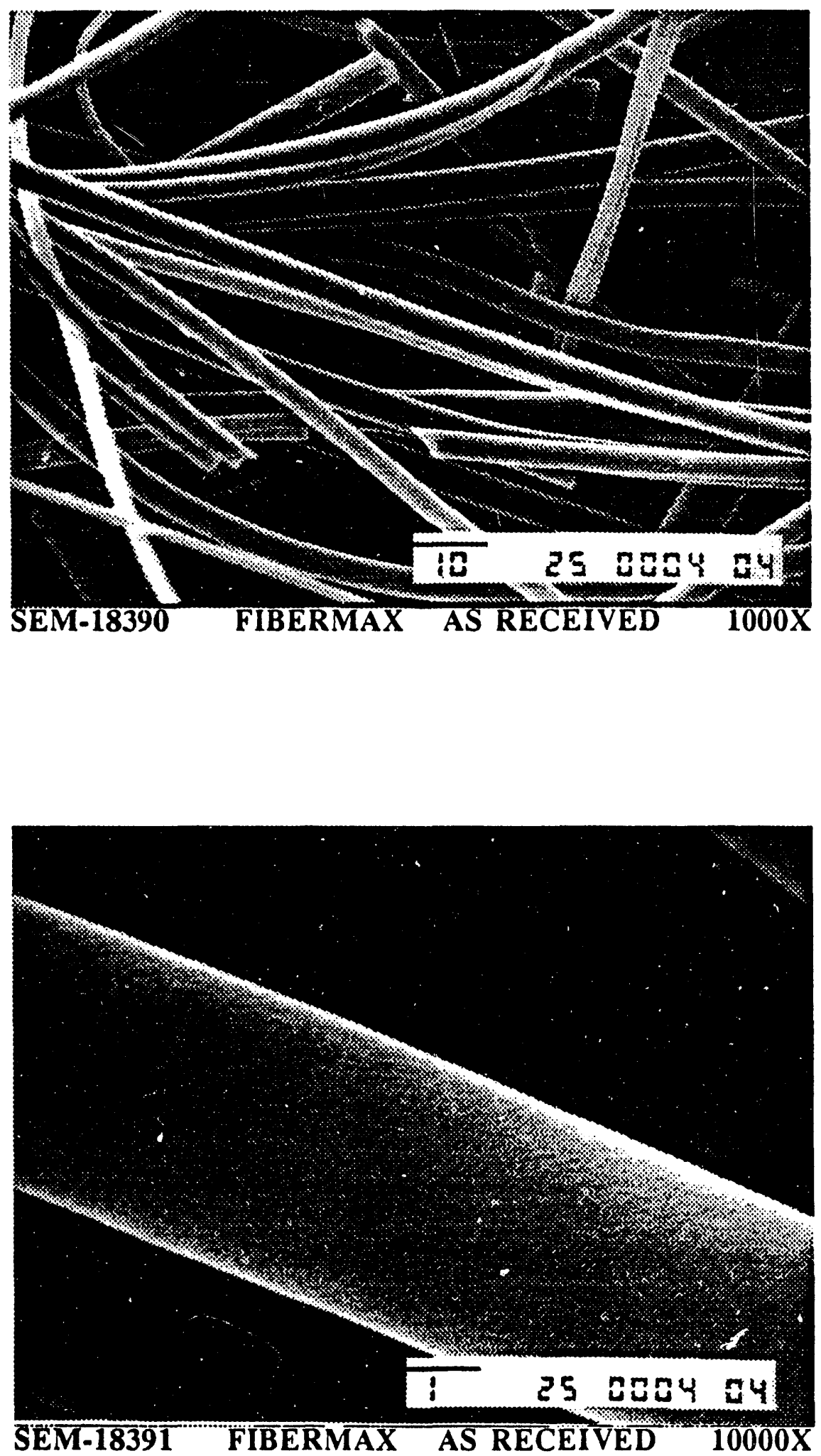

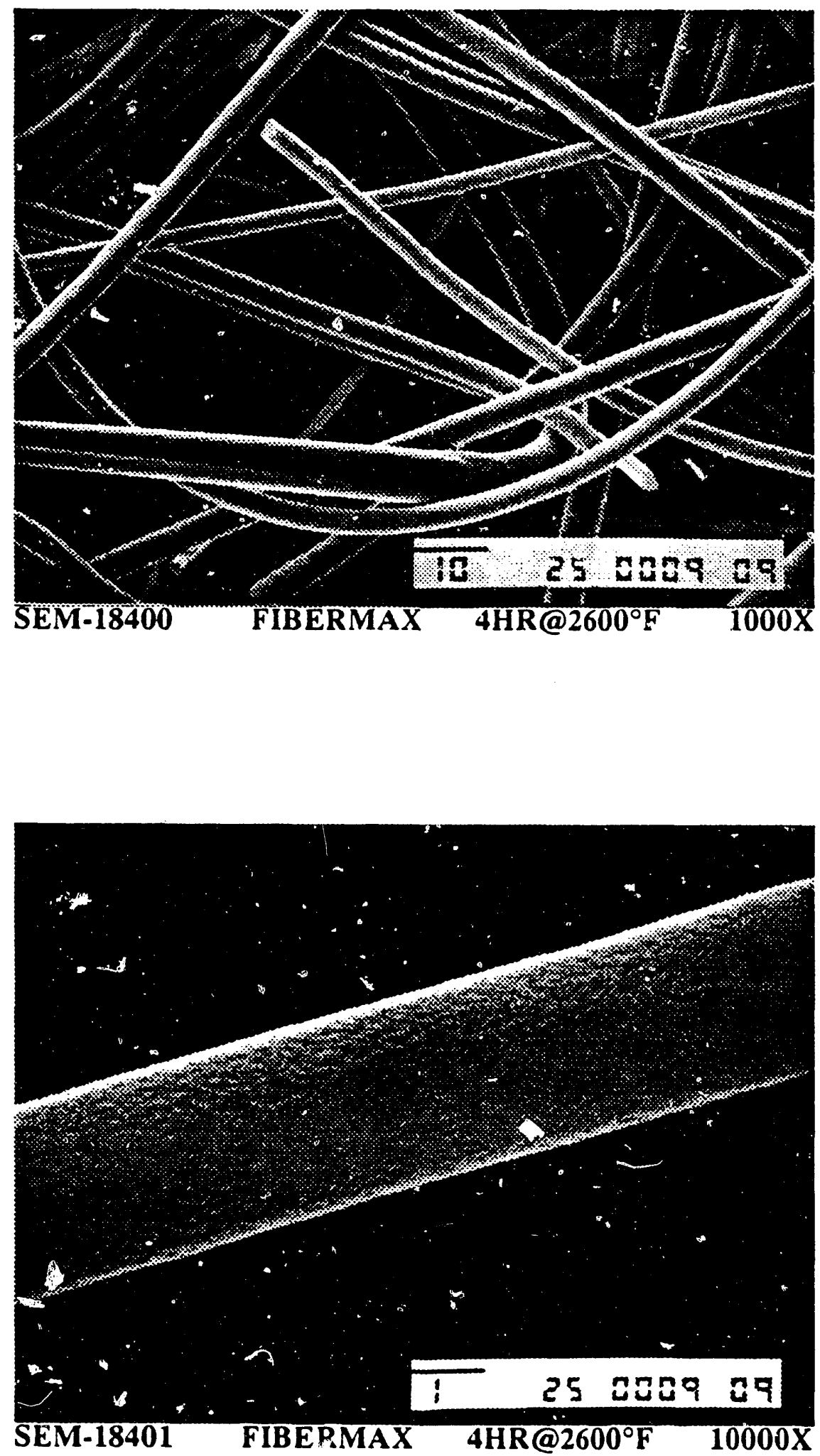

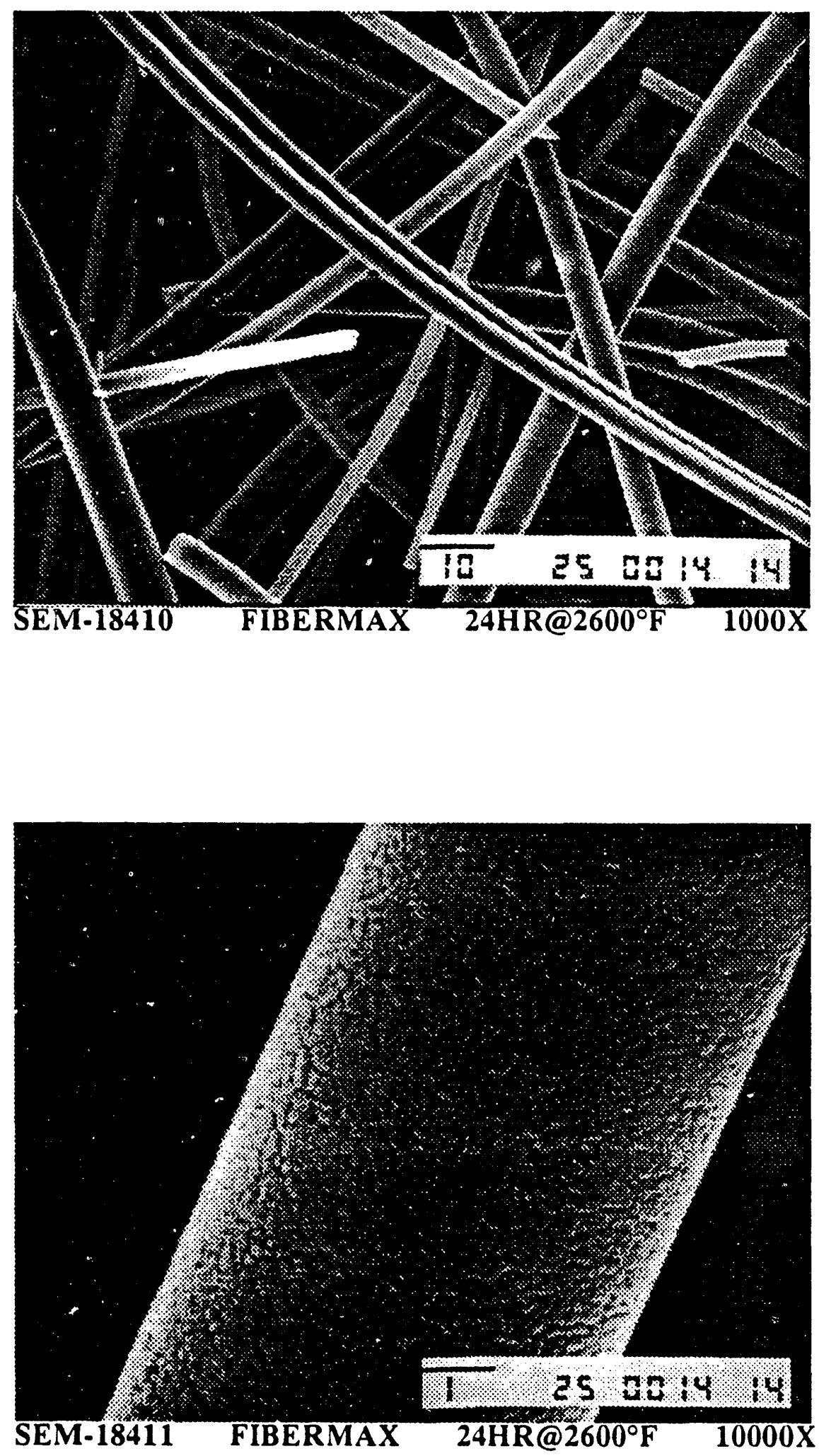

A. 3.16 

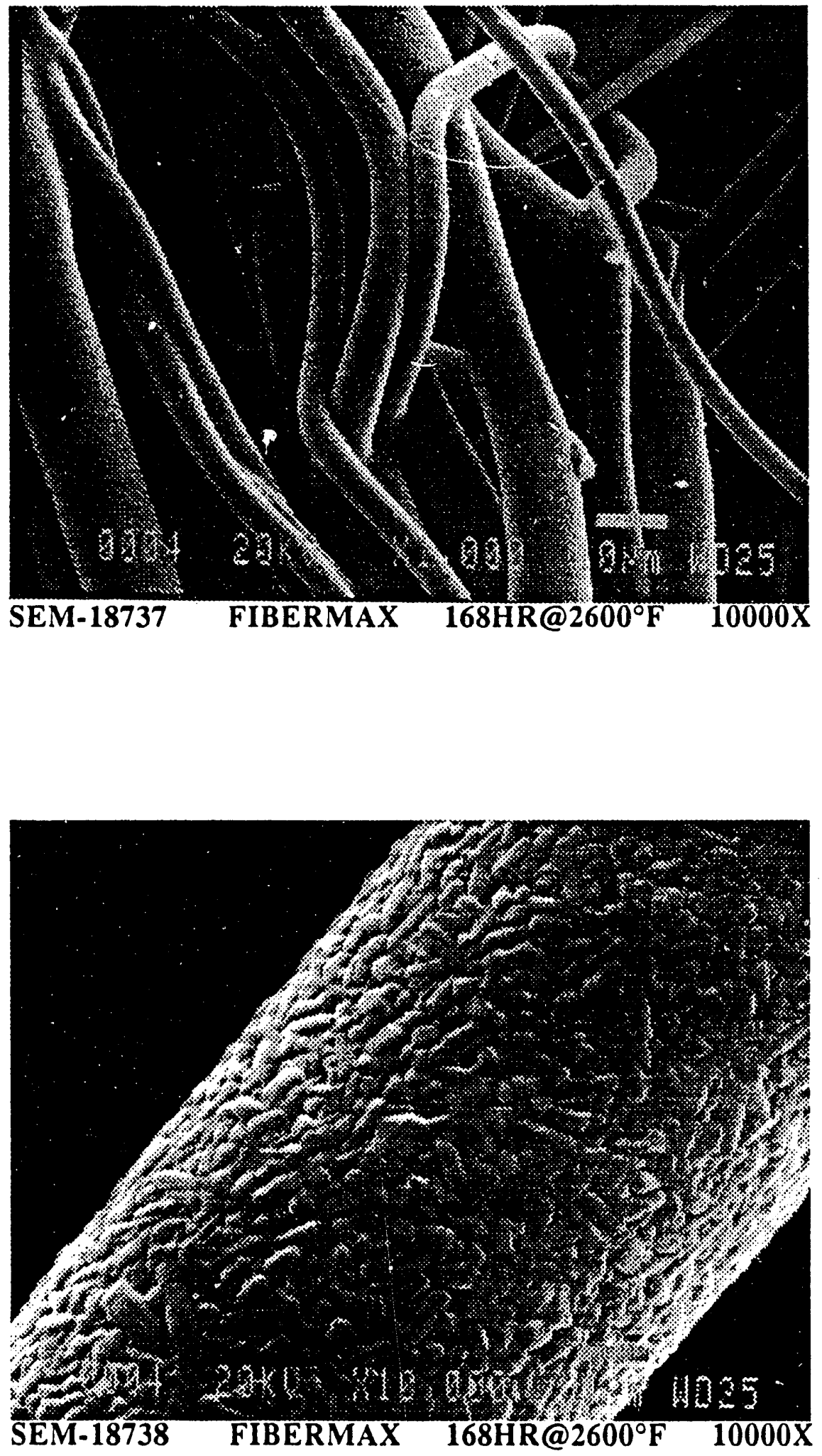

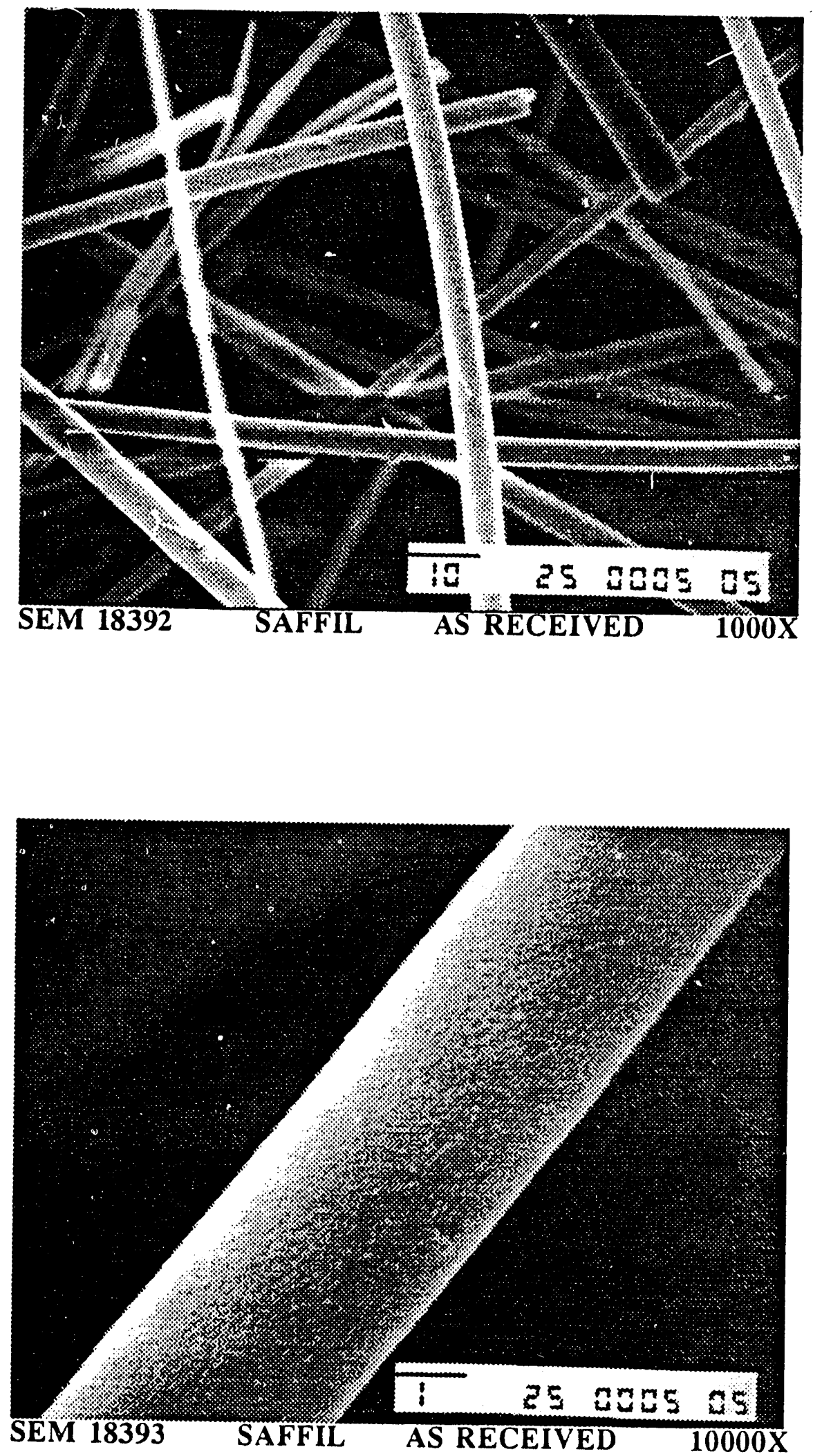

A. 3.18 

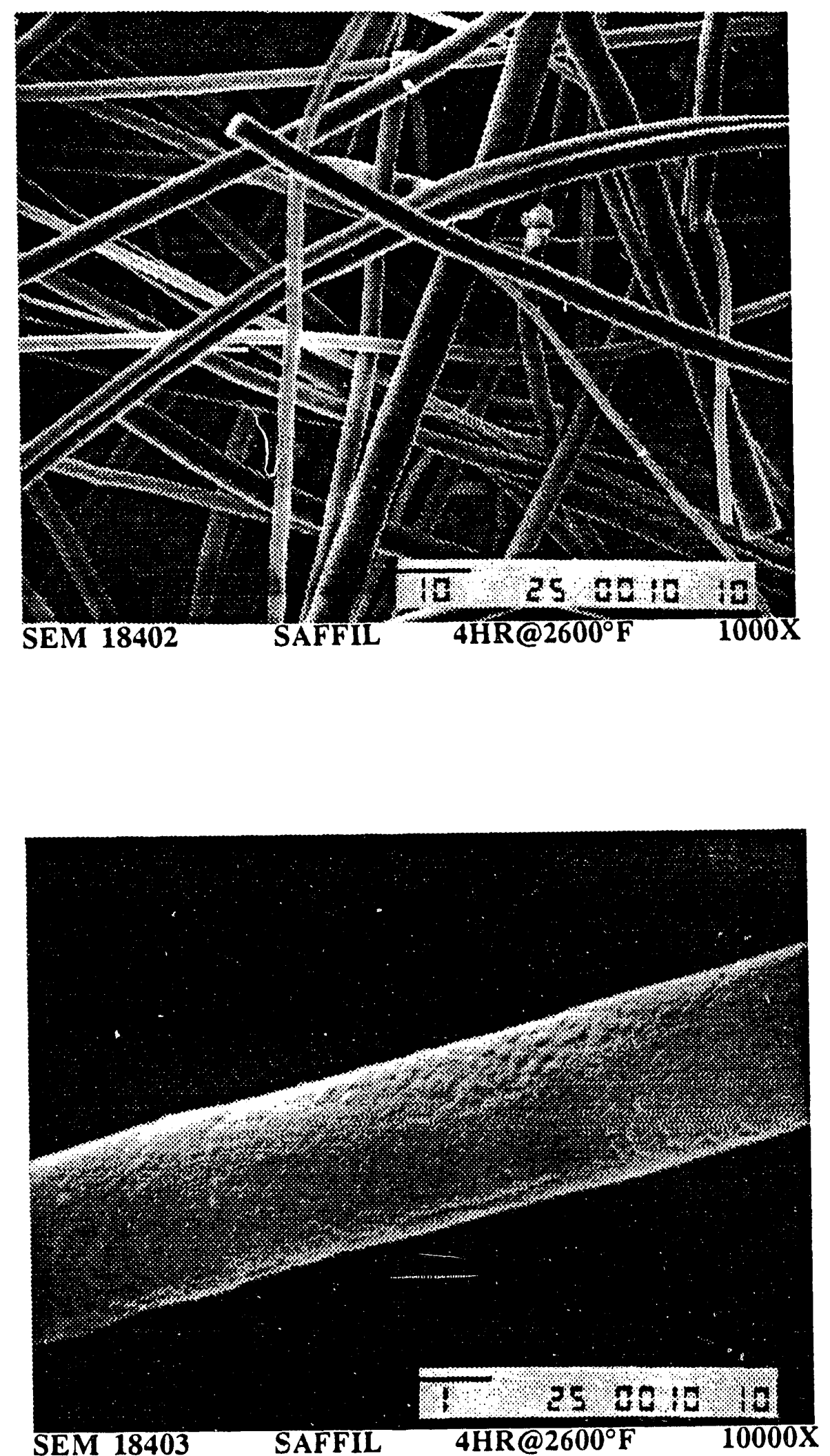

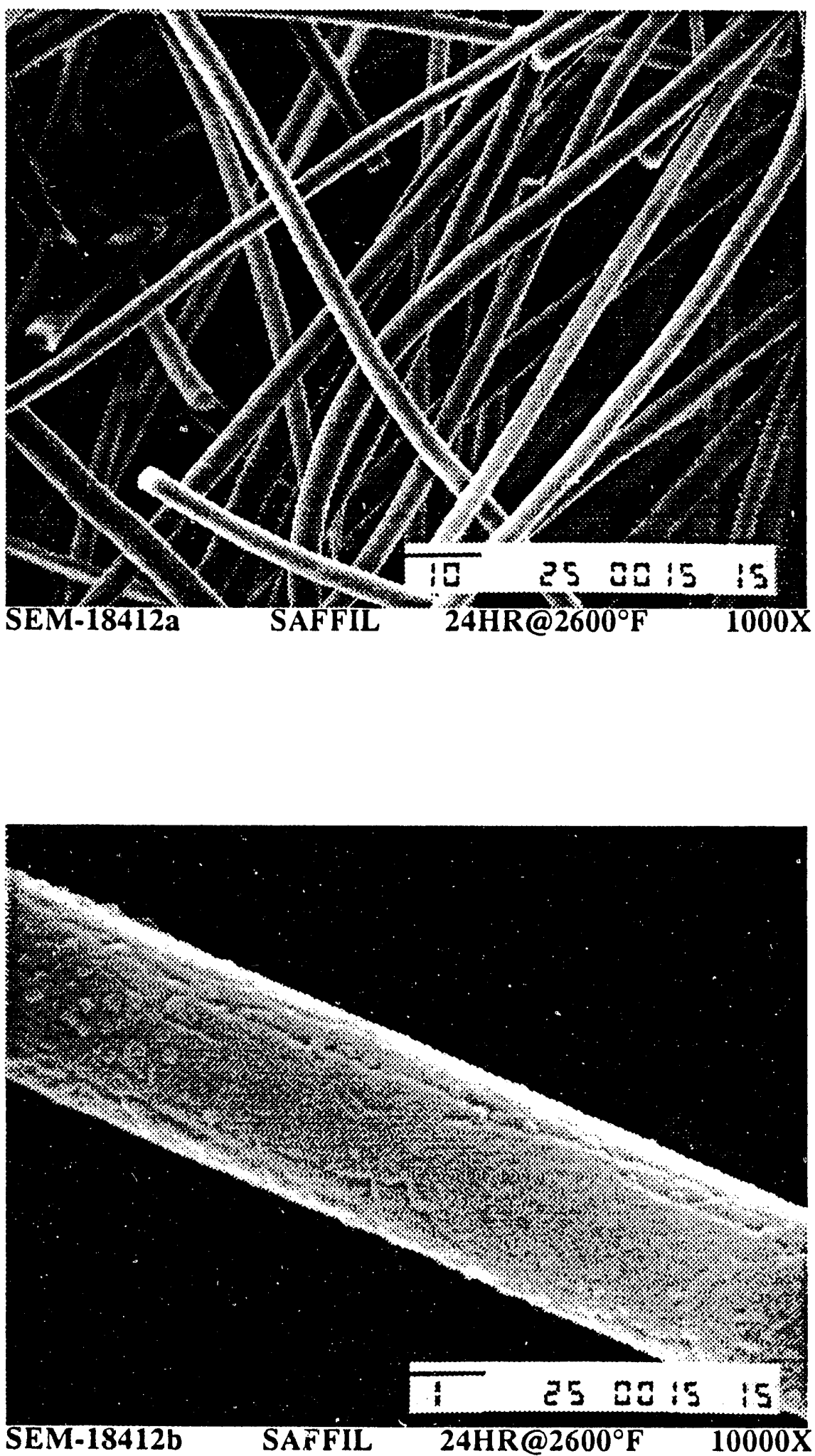

A. 3.20 

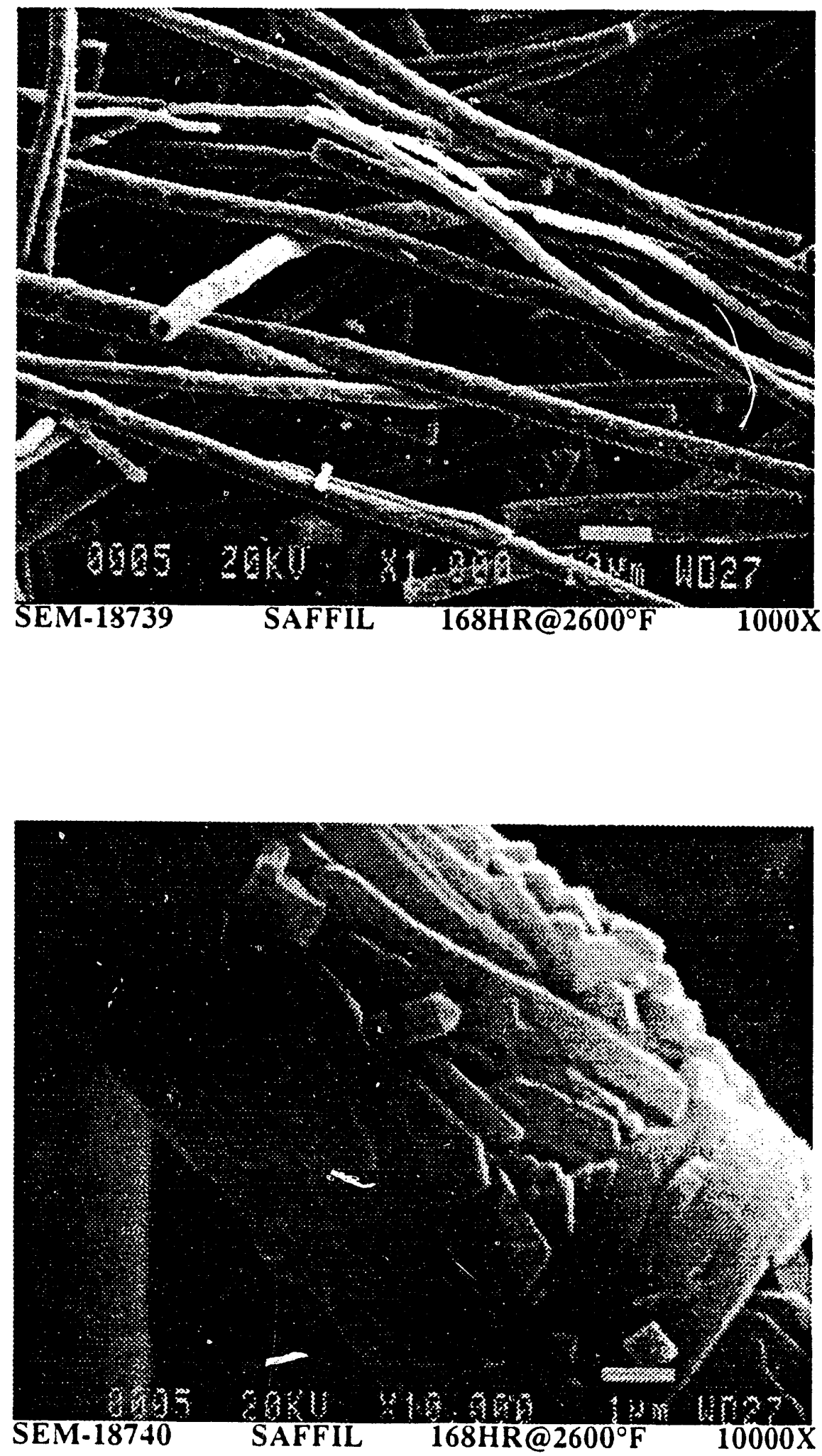

A. 3.21 

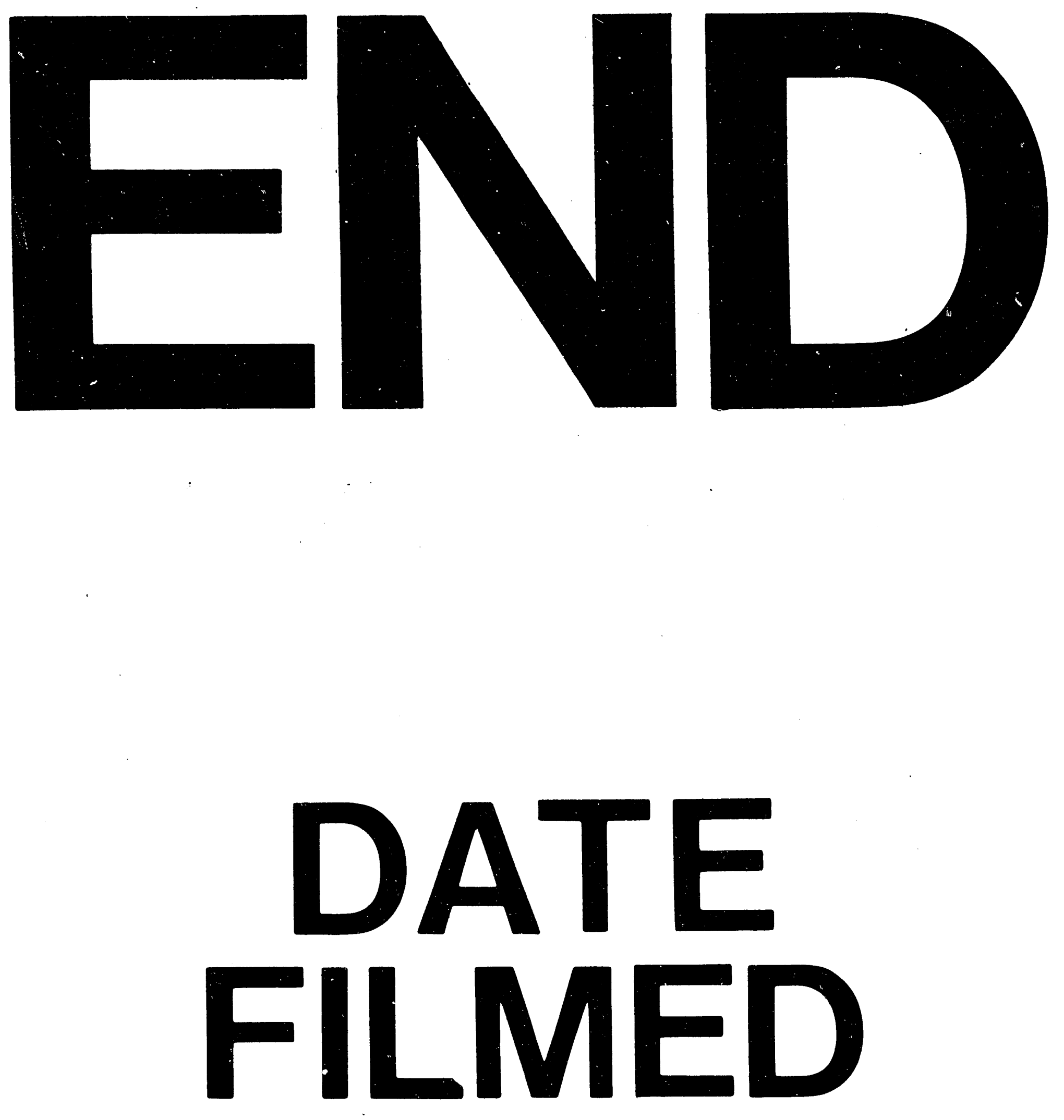

I

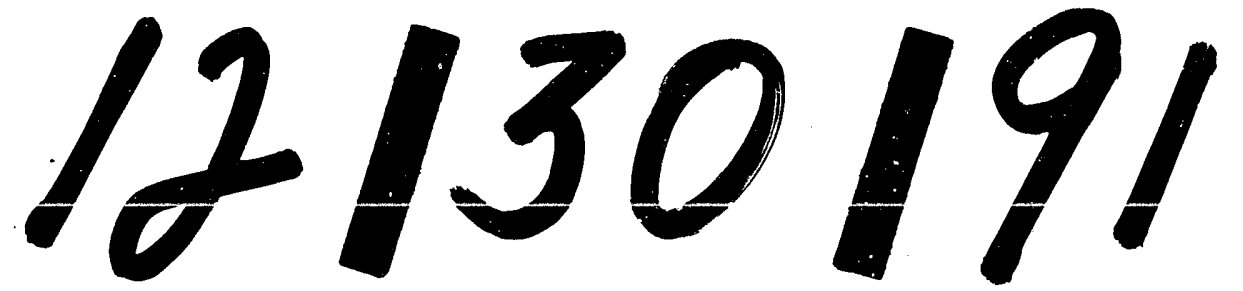


